\title{
Xanthoceras sorbifolium Bunge: A Review on Botany, Phytochemistry, Pharmacology, and Applications
}

\author{
Erhuan Zang ${ }^{1 \dagger}$, Bin Qiu $^{2 \dagger}$, Namuhan Chen ${ }^{3,4}$, Caifeng $\mathrm{Li}^{3,4}$, Qian Liu ${ }^{1}$, Min Zhang ${ }^{1}$, \\ Yuchao Liu ${ }^{1,5}$ and Minhui $\mathrm{Li}^{1,3,4,5,6 *}$
}

${ }^{1}$ Department of Pharmacy, Baotou Medical College, Baotou, China, ${ }^{2}$ School of Chinese Materia Medica and Yunnan Key Laboratory of Southern Medicinal Resource, Yunnan University of Chinese Medicine, Kunming, China, ${ }^{3}$ Pharmaceutical Laboratory, Inner Mongolia Hospital of Traditional Chinese Medicine, Hohhot, China, ${ }^{4}$ Pharmaceutical Laboratory, Inner Mongolia Institute of Traditional Chinese Medicine, Hohhot, China, ${ }^{5}$ Office of Academic Research, Qiqihar Medical University, Qiqihar, China, ${ }^{6}$ Inner Mongolia Key Laboratory of Characteristic Geoherbs Resources Protection and Utilization, Baotou, China

OPEN ACCESS

Edited by:

Alejandro Urzua,

University of Santiago, Chile

Reviewed by:

Junwei He,

Jiangxi University of Traditional

Chinese Medicine, China

Guang-Bo Ge,

Shanghai University of Traditional

Chinese Medicine, China

*Correspondence:

Minhui Li

prof_liminhui@yeah.net

${ }^{+}$These authors have contributed equally to this work

Specialty section:

This article was submitted to

Ethnopharmacology,

a section of the journal

Frontiers in Pharmacology

Received: 12 May 2021 Accepted: 16 August 2021 Published: 30 August 2021

Citation:

Zang E, Qiu B, Chen N, Li C, LiU Q, Zhang M, LiU Y and Li M (2021) Xanthoceras sorbifolium Bunge: $A$ Review on Botany, Phytochemistry,

Pharmacology, and Applications.

Front. Pharmacol. 12:708549.

doi: 10.3389/fphar.2021.708549
Xanthoceras sorbifolium Bunge (Sapindaceae) is a native Chinese plant with promising applications as a biofuel feedstock and a source of novel drugs. Historical records and documents from different periods have mentioned the use of $X$. sorbifolium and its botanical constituents in treating diseases, highlighting its central role in Chinese and Mongolian traditional medicinal therapies. Phytochemical research has focused on the husks, leaves, trunks, and branches of this herb. A total of 278 chemical compounds have been isolated and divided into 8 categories: triterpenoids, flavonoids, phenylpropanoids, steroids, phenols, fatty acids, alkaloids, and quinones. Modern pharmacological studies on $X$. sorbifolium have demonstrated positive effects on learning and memory, as well as anti-inflammatory, anti-tumor, and anti-oxidative properties. This review provides a comprehensive analysis of the available research on $X$. sorbifolium, focusing on the relationship between chemical constituents, traditional uses, and pharmacological effects. We also assess the potential for therapeutic and other applications of this plant in support of further research and development of $X$. sorbifolium.

Keywords: Xanthoceras sorbifolium, medicinal plants, phytochemistry, pharmacology, applications

\section{INTRODUCTION}

Xanthoceras sorbifolium, belonging to the family Sapindaceae and genus Xanthoceras, is a monotypic species widely distributed throughout China. The plant, commonly called the yellow horn or golden horn (Xu and $\mathrm{Yu}, 2010)$, is a valuable woody oil crop used to extract edible and medicinal ingredients, produce biofuels, and for greening of deserts. In China, X. sorbifolium was first recorded in the Chinese Materia Medica "Jiu Huang Ben Cao" (1406 AD) under the name "Wen Guan Hua." It is used to treat arterial sclerosis, hyperlipidemia, hypertension, chronic hepatitis, and rheumatism (Wang, 1998; Li et al., 2007a). More importantly, each part of X. sorbifolium has a certain medicinal and health value and is used to prevent and treat diseases. The extract prepared from its husks has anti-inflammatory and anti-cancer properties; it also inhibits human immunodeficiency virus (HIV) protease and improves learning and memory, among other pharmacological effects (Zhang et al., 2016). The flower and calyx contain baicalin, which has antipyretic, sleep-inducing, anti-spasmodic, and anti-tumor effects. Their seeds can be used to prevent and cure arterial sclerosis (Wan et al., 2013). In Inner Mongolia, the trunks and branches were used to treat arthritis, as discussed in the 
Chinese Pharmacopeia in 1977 (Commission NP, 1977). Xanthoceraside is a triterpenoid saponin extracted from the husks of $X$. sorbifolium. It has many biological activities, such as improving learning and memory, and has anti-cancer and antiinflammatory properties. Xanthoceraside may become a candidate for the prevention and treatment of Alzheimer's disease (AD) (Yang C. Y. et al., 2016).

In addition to its medicinal value, $X$. sorbifolium has unique applications in the food and chemical industries, and in environmental protection (Wan et al., 2013). The seeds of $X$. sorbifolium are rich in unsaturated fatty acids and are used to prepare cooking oil. The kernels can be incorporated into seasoned dairy products or processed protein drinks. The leaves can also be used as tea (its protein content is higher than that of black tea), and the caffeine content is similar to that of flower tea (Wang, 1998). Xanthoceras sorbifolium can also be used in cosmetics and to make biodiesel. The husks of $X$. sorbifolium (which are considered by-products) can be used to produce chemical materials, such as activated carbon, furfural, xylitol, and alcohol (Yi et al., 2011). Furthermore, this herb is an excellent windbreak and a pioneer sand fixation species that is resistant to drought, wind, and sand. They are also easy to cultivate. Extensive $X$. sorbifolium plantations have been established in northern China to combat desertification. Other properties of this plant include cold tolerance, soil resistance, and high seed oil content. Therefore, it has become the preferred oil and eco-economic tree species for greening, returning farmland to forest, providing shelter against wind, and preventing sand erosion in mountainous areas (Bai et al., 2010). Xanthoceras sorbifolium has broad development prospects, especially in the fields of food, medicine, energy, and ecology. It is regarded as one of the most promising tree species for sustainable development in the 21 st century.

In recent years, phytochemistry research has isolated 278 components from different sections of $X$. sorbifolium, including triterpenoids, flavonoids, phenylpropanoids, steroids, phenols, fatty acids, alkaloids, quinones, and others (Cheng et al., 2001; Wan et al., 2013; Yang C. Y. et al., 2016). These abundant bioactive components have a wide range of pharmacological activities (Yang L. et al., 2020; Zhang et al., 2020; Hao et al., 2021), including improved learning ability and memory (Ji et al., 2014; Rong et al., 2019), anti-inflammatory (Qi et al., 2013), antitumor (Wang et al., 2016a), antioxidant (Zhang et al., 2015; Yang CY. et al., 2016), anti-HIV (Li et al., 2007b), and vascular relaxation effects ( $\mathrm{Ma}$ et al., 2000), as well as inhibition of pancreatic lipase activity (Geng et al., 2014). Increasing evidence regarding the medicinal value and excellent bioenergy value of $X$. sorbifolium highlights the need to evaluate its practical applications.

This review systematically summarizes the botanical and morphological characteristics, pharmacological effects, recorded medicinal history, and ethnic medicine applications of this herb. Through an extensive analysis of all relevant articles and books, we present the remarkable achievements and shortcomings of existing research, as well as some possible perspectives and trends for future studies on $X$. sorbifolium. This comprehensive review aims to provide a reference for future research, development, and utilization of X. sorbifolium.

\section{METHODOLOGY AND LITERATURE SEARCH STRATEGY}

The extensive literature search involved articles, papers, and books from different sources, such as Embase-Elsevier, PubMed, Science Direct, SciFinder Scholar, Google Scholar, Baidu Scholar, CNKI, and Web of Science. The search strategy was based on combining different keywords, such as $X$. sorbifolium, traditional uses, phytochemistry, pharmacology, and review. The literature search results included publications from 1960 to 2021 to ensure a systematic analysis of data on $X$. sorbifolium. Literature screening involved initially reading the keywords, title, and abstract of retrieved literature to identify the article's relevance to this research. Potentially relevant literature was then downloaded, and the full text was assessed. Any relevant literature was included in the analysis. Any literature that did not conform to the theme was excluded. The chemical structural formula used in this manuscript was created using ChemDraw 18.0 (PerkinElmer, United States).

\section{BOTANY AND CHARACTERISTICS}

Xanthoceras sorbifolium grows to $2-5 \mathrm{~m}$ in height with stout branchlets that are brownish red in color and glabrous with tileliked bud scales arranged on the top and side buds. The leaf peduncle is $15-30 \mathrm{~cm}$ in length. There are $4-8$ pairs of leaflets, membranous or papery, lanceolate or subovate. The lateral veins are slender and slightly raised on both sides. The inflorescence grows before or simultaneously with the leaves. The flowers are monoecious and the inflorescence is terminal. The axillary of the male inflorescences is $12-20 \mathrm{~cm}$ in length and erect with a short total pedicel and a residual bud scale at the base. The pedicel is $1.2-2 \mathrm{~cm}$ in length. The bracts are $0.5-1 \mathrm{~cm}$ long. The sepals are $6-7 \mathrm{~mm}$ long with gray hairs on both sides. The petals are white, but the base is purplish-red or yellow. The fruit consists of a capsule that is $5-6 \mathrm{~cm}$ in diameter with three seed compartments that are $1-1.5 \mathrm{~cm}$ in diameter. The number of seeds per compartment can vary from one to six. The seeds are black and shiny (Editorial Board of Flora of China, 1985; Xu and $Y u, 2010)$. The different parts of $X$. sorbifolium are listed in Figure 1.

Xanthoceras sorbifolium grows in temperate and warm temperate zones, where the altitude ranges from 300 to $2000 \mathrm{~m}$ and the horizontal range is $28^{\circ} 34^{\prime}-47^{\circ} 20^{\prime} \mathrm{E}$ and $73^{\circ} 20^{\prime}-120^{\circ} 25^{\prime} \mathrm{N}$. The species is mainly distributed in 18 provinces of China, including Inner Mongolia, Shaanxi, Shanxi, Hebei, and Henan. According to a resource survey, Chifeng in Inner Mongolia has the most concentrated populations and currently possesses the largest mangrove forest in China. The species is long-lived (up to 1,000 years), and it can grow in soil in $\mathrm{pH}$ ranges from 7 to 8.5 . It can tolerate 



FIGURE 1 | Xanthoceras sorbifolium Bunge. (A). Whole plant; (B). Fruits; (C). Seeds; (D). Flowers; (E). Wood (The thunks and branches); (F). Leaves; (G). Husks.

drought, low temperature, and soils that constitute clay, sand, or loam, including those that are alkaline, and of low fertility. It also grows well in deserted mountains, barren gullies, sandy lands, and steep hillsides (Mou et al., 2008; Xie et al., 2010).

\section{PHYTOCHEMISTRY}

Among the 278 compounds that have been isolated and identified from $X$. sorbifolium, triterpenes and flavonoids have been regarded as characteristic and main bioactive substances due to their variety, content, and pharmacological activities (Yang C. Y. et al., 2016). The structures and relevant references for these compounds are listed in Figures 2-10 and Table 1.

\section{Triterpenoids}

Triterpenoids represent a large part of the chemical constituents in the X. sorbifolium, with 124 triterpenoid compounds having been identified from the husks, carpophores, leaves, and seeds (compounds 1-124, Figure 2). Yu et al. (2012a) extracted the seed oil residue of $X$. sorbifolium. The compounds were separated by D-101 macroporous resin, silica gel column chromatography, Sephadex LH-20, octadecylsilyl (ODS) column, and purified by prep-HPLC chromatography. Seven new oleanane-type triterpenoid saponins, sorbifoliaside A-J (35-44), were identified by MS, ${ }^{1} \mathrm{H}-\mathrm{NMR},{ }^{13} \mathrm{C}-\mathrm{NMR},{ }^{1} \mathrm{H}-{ }^{1} \mathrm{H}$ COSY, HSQC, HMBC, NOESY, and TOCSY methods (Yu et al., 2012a; Yu et al., 2012b). Wang et al. (2016b) extracted $X$. sorbifolium with ethanol, analyzed the compounds by Sephadex LH-20, ODS, UV, MS, and NMR, and identified triterpenoids: $\quad 3-O-\beta$-D-glucopyranosyl-28-O-[ $\alpha$-L-rhamnopyranosyl $(1 \rightarrow 2)]-\beta$-D-glucopyranosyl-16-deoxybarringtogenol C (63), 3-O-
[ $\beta$-D-glucopyranosyl $\quad(1 \rightarrow 6)]$-[(3-O-angeloyl)- $\beta$-D-glucopyranosyl $(1 \rightarrow 2)]-\beta$-D-glucopyranosyl-28-O-[ $\beta$-D-glucopyranosyl

$(1 \rightarrow 6)]$ - $\alpha$-L-rhamanopyranosyl $(1 \rightarrow 2)]-\beta$-D-glucopyranosyl-16deoxybarringtogenol C (64),3-O-[ $\beta$-D-glucopyranosyl $(1 \rightarrow 6)]$-(3$O$-angeloyl)- $\beta$-D-glucopyranosyl-28-O-[ $\alpha$-L-rhamanopyranosyl $(1 \rightarrow 2)]$ - $\beta$-D-glucopyranosyl-16-deoxybarringtogenol C $\quad$ (65) (Wang et al., 2016b). Chen et al. (2020a) extracted 70\% ethanol from the husk of $X$. sorbifolium; separated and identified a series of compounds by D-101 macroporous resin, silica gel column, ODS column, and HPLC chromatography; and isolated compounds 108-123 for the first time (Chen et al., 2020a; Chen et al., 2020b). The chemical structures of triterpenoids are provided in Figure 2.

\section{Flavonoids}

Flavonoids are a group of naturally occurring compounds that contain a benzopyran heterocycle linked to a benzene ring (Testai, 2015). Currently, 48 flavonoids (125-172) have been obtained from the trunks and branches, leaves, husks, and flowers of $X$. sorbifolium. Among these compounds, quercetin and myricetin are the main aglycons. Zhang and Bao (2000) used polyamide and silica gel column chromatography to isolate the chemical constituents of lignum xanthocerais. Two flavonoids, $2 \alpha, 3 \beta$-dihydroquercetin (158), epicatechin (163), were identified by UV, MS, ${ }^{1} \mathrm{H}-\mathrm{NMR},{ }^{13} \mathrm{C}-\mathrm{NMR}$, and $2 \mathrm{D}-\mathrm{NMR}$ (Zhang and Bao, 2000). Wu (2017) separated and purified the acetone extract of lignum xanthocerais by ODS, Sephadex LH-20, and preparative high-performance liquid chromatography (HPLC). After that, eight flavonoids, namely myricitrin (134), rutin (140), 3, 3', 4', 5, 7-pentahydroxyflavanone (156), dihydromyricetin (159), catechin (161), gallocatechin (162), epigallocatechin (165), procyanidin A-2 (169), were identified by Thin layer 


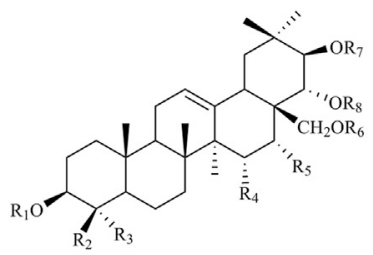

1. $\mathrm{R}_{1}=\mathrm{H} ; \mathrm{R}_{2}=\mathrm{R}_{3}=\mathrm{CH}_{3} ; \mathrm{R}_{4}=\mathrm{R}_{5}=\mathrm{OH} ; \mathrm{R}_{6}=\mathrm{R}_{7}=\mathrm{R}_{8}=\mathrm{H}$ 2. $\mathrm{R}_{1}=\mathrm{H} ; \mathrm{R}_{2}=\mathrm{R}_{3}=\mathrm{CH}_{3} ; \mathrm{R}_{4}=\mathrm{R}_{5}=\mathrm{OH} ; \mathrm{R}_{6}=\mathrm{H} ; \mathrm{R}_{7}=$ Ang $; \mathrm{R}_{8}=\mathrm{H}$ 3. $\mathrm{R}_{1}=\mathrm{H} ; \mathrm{R}_{2}=\mathrm{R}_{3}=\mathrm{CH}_{3} ; \mathrm{R}_{4}=\mathrm{R}_{5}=\mathrm{OH} ; \mathrm{R}_{6}=\mathrm{R}_{7}=\mathrm{H} ; \mathrm{R}_{8}=\mathrm{Ang}$ 4. $\mathrm{R}_{1}=\mathrm{H} ; \mathrm{R}_{2}=\mathrm{R}_{3}=\mathrm{CH}_{3} ; \mathrm{R}_{4}=\mathrm{R}_{5}=\mathrm{OH} ; \mathrm{R}_{6}=\mathrm{H} ; \mathrm{R}_{7}=\mathrm{R}_{8}=$ Ang 5. $\mathrm{R}_{1}=\mathrm{H} ; \mathrm{R}_{2}=\mathrm{CH}_{2} \mathrm{OH} ; \mathrm{R}_{3}=\mathrm{CH}_{3} ; \mathrm{R}_{4}=\mathrm{R}_{5}=\mathrm{OH} ; \mathrm{R}_{6}=\mathrm{H} ; \mathrm{R}_{7}=\mathrm{R}_{8}=$ Ang 6. $\mathrm{R}_{1}=\mathrm{H} ; \mathrm{R}_{2}=\mathrm{R}_{3}=\mathrm{CH}_{3} ; \mathrm{R}_{4}=\mathrm{R}_{5}=\mathrm{OH} ; \mathrm{R}_{6}=\mathrm{Glc} ; \mathrm{R}_{7}=\mathrm{Ang} ; \mathrm{R}_{8}=\mathrm{H}$

7. $\mathrm{R}_{1}=\mathrm{H} ; \mathrm{R}_{2}=\mathrm{CH}_{2} \mathrm{OH} ; \mathrm{R}_{3}=\mathrm{CH}_{3} ; \mathrm{R}_{4}=\mathrm{R}_{5}=\mathrm{OH} ; \mathrm{R}_{6}=\mathrm{H} ; \mathrm{R}_{7}=\mathrm{Ang} ; \mathrm{R}_{8}=\mathrm{H}$

8. $\mathrm{R}_{1}=\mathrm{a} ; \mathrm{R}_{2}=\mathrm{H} ; \mathrm{R}_{3}=\mathrm{CH}_{3} ; \mathrm{R}_{4}=\mathrm{R}_{5}=\mathrm{OH} ; \mathrm{R}_{6}=\mathrm{H} ; \mathrm{R}_{7}=\mathrm{Ang} ; \mathrm{R}_{8}=\mathrm{i}-\mathrm{Bu}$

9. $\mathrm{R}_{1}=\mathrm{a} ; \mathrm{R}_{2}=\mathrm{OH} ; \mathrm{R}_{3}=\mathrm{CH}_{3} ; \mathrm{R}_{4}=\mathrm{R}_{5}=\mathrm{OH} ; \mathrm{R}_{6}=\mathrm{H} ; \mathrm{R}_{7}=$ Ang; $\mathrm{R}_{8}=$ Ang

10. $\mathrm{R}_{1}=\mathrm{a} ; \mathrm{R}_{2}=\mathrm{H} ; \mathrm{R}_{3}=\mathrm{CH}_{3} ; \mathrm{R}_{4}=\mathrm{R}_{5}=\mathrm{OH} ; \mathrm{R}_{6}=\mathrm{H} ; \mathrm{R}_{7}=\mathrm{R}_{8}=$ Ang

11. $\mathrm{R}_{1}=\mathrm{a} ; \mathrm{R}_{2}=\mathrm{H} ; \mathrm{R}_{3}=\mathrm{CH}_{3} ; \mathrm{R}_{4}=\mathrm{R}_{5}=\mathrm{OH} ; \mathrm{R}_{6}=2$-methylbutanoyl $; \mathrm{R}_{7}=$ Ang; $\mathrm{R}_{8}=2$-methylbutanoyl

12. $\mathrm{R}_{1}=\mathrm{a} ; \mathrm{R}_{2}=\mathrm{R}_{3}=\mathrm{CH}_{3} ; \mathrm{R}_{4}=\mathrm{R}_{5}=\mathrm{OH} ; \mathrm{R}_{6}=\mathrm{H} ; \mathrm{R}_{7}=\mathrm{R}_{8}=\mathrm{Ang}$

13. $\mathrm{R}_{1}=\mathrm{b} ; \mathrm{R}_{2}=\mathrm{R}_{3}=\mathrm{CH}_{3} ; \mathrm{R}_{4}=\mathrm{R}_{5}=\mathrm{OH} ; \mathrm{R}_{6}=\mathrm{Rha}(1 \rightarrow 2) \mathrm{Glc} ; \mathrm{R}_{7}=\mathrm{R}_{8}=\mathrm{H}$

14. $\mathrm{R}_{1}=\mathrm{e} ; \mathrm{R}_{2}=\mathrm{R}_{3}=\mathrm{CH}_{3} ; \mathrm{R}_{4}=\mathrm{R}_{5}=\mathrm{OH} ; \mathrm{R}_{6}=\mathrm{H} ; \mathrm{R}_{7}=\mathrm{R}_{8}=$ Ang

15. $\mathrm{R}_{1}=$ Glc $(1 \rightarrow 2)-\left(6-\mathrm{O}\right.$-methyl-GluA; $\mathrm{R}_{2}=\mathrm{R}_{3}=\mathrm{CH}_{3} ; \mathrm{R}_{4}=\mathrm{R}_{5}=\mathrm{OH} ; \mathrm{R}_{6}=\mathrm{H} ; \mathrm{R}_{7}=\mathrm{R}_{8}=$ Ang

16. $\mathrm{R}_{1}=\mathrm{Glc}(1 \rightarrow 2)-\left(6-\mathrm{O}\right.$-methyl-GluA; $\mathrm{R}_{2}=\mathrm{R}_{3}=\mathrm{CH}_{3} ; \mathrm{R}_{4}=\mathrm{R}_{5}=\mathrm{OH} ; \mathrm{R}_{6}=\mathrm{H} ; \mathrm{R}_{7}=3^{\prime}, 4^{\prime}$-di-O-Ang-Fuc; $\mathrm{R}_{8}=\mathrm{Ac}$

17. $\mathrm{R}_{1}=\mathrm{a} ; \mathrm{R}_{2}=\mathrm{R}_{3}=\mathrm{CH}_{3} ; \mathrm{R}_{4}=\mathrm{R}_{5}=\mathrm{OH} ; \mathrm{R}_{6}=\mathrm{H} ; \mathrm{R}_{7}=\mathrm{R}_{8}=\mathrm{Ang}$

18. $\mathrm{R}_{1}=\mathrm{f} ; \mathrm{R}_{2}=\mathrm{R}_{3}=\mathrm{CH}_{3} ; \mathrm{R}_{4}=\mathrm{R}_{5}=\mathrm{OH} ; \mathrm{R}_{6}=\mathrm{H} ; \mathrm{R}_{7}=\mathrm{R}_{8}=$ Ang

19. $\mathrm{R}_{1}=\mathrm{e} ; \mathrm{R}_{2}=\mathrm{CH}_{2} \mathrm{OH} ; \mathrm{R}_{3}=\mathrm{CH}_{3} ; \mathrm{R}_{4}=\mathrm{R}_{5}=\mathrm{OH} ; \mathrm{R}_{6}=\mathrm{H} ; \mathrm{R}_{7}=\mathrm{R}_{8}=$ Ang

20. $\mathrm{R}_{1}=\mathrm{a} ; \mathrm{R}_{2}=\mathrm{R}_{3}=\mathrm{CH}_{3} ; \mathrm{R}_{4}=\mathrm{R}_{5}=\mathrm{OH} ; \mathrm{R}_{6}=\mathrm{H} ; \mathrm{R}_{7}=\mathrm{R}_{8}=$ Ang

21. $\mathrm{R}_{1}=\mathrm{OH} ; \mathrm{R}_{2}=\mathrm{R}_{3}=\mathrm{CH}_{3} ; \mathrm{R}_{4}=\mathrm{R}_{5}=\mathrm{OH} ; \mathrm{R}_{6}=\mathrm{H} ; \mathrm{R}_{7}=\mathrm{R}_{8}=\mathrm{Ang}$

22. $\mathrm{R}_{1}=\mathrm{H} ; \mathrm{R}_{2}=\mathrm{R}_{3}=\mathrm{CH}_{3} ; \mathrm{R}_{4}=\mathrm{H} ; \mathrm{R}_{5}=\mathrm{OH} ; \mathrm{R}_{6}=\mathrm{R}_{7}=\mathrm{R}_{8}=\mathrm{H}$

23. $\mathrm{R}_{1}=\mathrm{H} ; \mathrm{R}_{2}=\mathrm{R}_{3}=\mathrm{CH}_{3} ; \mathrm{R}_{4}=\mathrm{H} ; \mathrm{R}_{5}=\mathrm{OH} ; \mathrm{R}_{6}=\mathrm{H} ; \mathrm{R}_{7}=$ epoxyangeloyl $; \mathrm{R}_{8}=$ Ang

24. $\mathrm{R}_{1}=\mathrm{H} ; \mathrm{R}_{2}=\mathrm{R}_{3}=\mathrm{CH}_{3} ; \mathrm{R}_{4}=\mathrm{H} ; \mathrm{R}_{5}=\mathrm{OH} ; \mathrm{R}_{6}=\mathrm{H} ; \mathrm{R}_{7}=\mathrm{g} ; \mathrm{R}_{8}=\mathrm{Ac}$

25. $\mathrm{R}_{1}=\mathrm{H} ; \mathrm{R}_{2}=\mathrm{R}_{3}=\mathrm{CH}_{3} ; \mathrm{R}_{4}=\mathrm{H} ; \mathrm{R}_{5}=\mathrm{OH} ; \mathrm{R}_{6}=\mathrm{H} ; \mathrm{R}_{7}=\mathrm{R}_{8}=$ Ang

26. $\mathrm{R}_{1}=\mathrm{H} ; \mathrm{R}_{2}=\mathrm{R}_{3}=\mathrm{CH}_{3} ; \mathrm{R}_{4}=\mathrm{H} ; \mathrm{R}_{5}=\mathrm{OH} ; \mathrm{R}_{6}=\mathrm{H} ; \mathrm{R}_{7}=\mathrm{R}_{8}=\mathrm{Ang}$

27. $\mathrm{R}_{1}=\mathrm{a} ; \mathrm{R}_{2}=\mathrm{H} ; \mathrm{R}_{3}=\mathrm{CH}_{3} ; \mathrm{R}_{4}=\mathrm{H} ; \mathrm{R}_{5}=\mathrm{OH} ; \mathrm{R}_{6}=\mathrm{H} ; \mathrm{R}_{7}=\mathrm{R}_{8}=\mathrm{Ang}$

28. $\mathrm{R}_{1}=\mathrm{e} ; \mathrm{R}_{2}=\mathrm{R}_{3}=\mathrm{CH}_{3} ; \mathrm{R}_{4}=\mathrm{H} ; \mathrm{R}_{5}=\mathrm{OH} ; \mathrm{R}_{6}=\mathrm{H} ; \mathrm{R}_{7}=\mathrm{d} ; \mathrm{R}_{8}=\mathrm{Ac}$

29. $\mathrm{R}_{1}=\mathrm{H} ; \mathrm{R}_{2}=\mathrm{R}_{3}=\mathrm{CH}_{3} ; \mathrm{R}_{4}=\mathrm{R}_{5}=\mathrm{OH} ; \mathrm{R}_{6}=\mathrm{H} ; \mathrm{R}_{7}=\mathrm{R}_{8}=\mathrm{Ang}$

30. $\mathrm{R}_{1}=\mathrm{H} ; \mathrm{R}_{2}=\mathrm{CH}_{2} \mathrm{OH} ; \mathrm{R}_{3}=\mathrm{CH}_{3} ; \mathrm{R}_{4}=\mathrm{OH} ; \mathrm{R}_{5}=\mathrm{OH} ; \mathrm{R}_{6}=\mathrm{H} ; \mathrm{R}_{7}=\mathrm{R}_{8}=$ Ang

31. $\mathrm{R}_{1}=\mathrm{Glc}(1 \rightarrow 6)[\mathrm{Ara}(1 \rightarrow 2)-\mathrm{Glc}] ; \mathrm{R}_{2}=\mathrm{R}_{3}=\mathrm{CH}_{3} ; \mathrm{R}_{4}=\mathrm{R}_{5}=\mathrm{OH} ; \mathrm{R}_{6}=\mathrm{H} ; \mathrm{R}_{7}=\mathrm{R}_{8}=$ Ang

32. $\mathrm{R}_{1}=\mathrm{H} ; \mathrm{R}_{2}=\mathrm{R}_{3}=\mathrm{CH}_{3} ; \mathrm{R}_{4}=\mathrm{R}_{5}=\mathrm{R}_{6}=\mathrm{R}_{7}=\mathrm{R}_{8}=\mathrm{H}$

33. $\mathrm{R}_{1}=\mathrm{H} ; \mathrm{R}_{2}=\mathrm{R}_{3}=\mathrm{CH}_{3} ; \mathrm{R}_{4}=\mathrm{H} ; \mathrm{R}_{5}=\mathrm{OAc} ; \mathrm{R}_{6}=\mathrm{H} ; \mathrm{R}_{7}=\mathrm{h} ; \mathrm{R}_{8}=\mathrm{H}$

34. $\mathrm{R}_{1}=\mathrm{Glc}(1 \rightarrow 6) \mathrm{Glc} ; \mathrm{R}_{2}=\mathrm{R}_{3}=\mathrm{CH}_{3} ; \mathrm{R}_{4}=\mathrm{R}_{5}=\mathrm{H} ; \mathrm{R}_{6}=\mathrm{i} ; \mathrm{R}_{7}=\mathrm{R}_{8}=\mathrm{H}$

35. $\mathrm{R}_{1}=\mathrm{Glc}(1 \rightarrow 6) \mathrm{Glc} ; \mathrm{R}_{2}=\mathrm{R}_{3}=\mathrm{R}_{4}=\mathrm{R}_{5}=\mathrm{H} ; \mathrm{R}_{6}=\mathrm{d} ; \mathrm{R}_{7}=\mathrm{R}_{8}=\mathrm{H}$

36. $\mathrm{R}_{1}=\mathrm{Glc}(1 \rightarrow 6) \mathrm{Glc} ; \mathrm{R}_{2}=\mathrm{R}_{3}=\mathrm{R}_{4}=\mathrm{H} ; \mathrm{R}_{5}=\mathrm{O} ; \mathrm{R}_{6}=\mathrm{d} ; \mathrm{R}_{7}=\mathrm{R}_{8}=\mathrm{H}$

37. $R_{1}=d ; R_{2}=R_{3}=R_{4}=H ; R_{5}==O ; R_{6}=G l c(1 \rightarrow 6) G l c ; R_{7}=R_{8}=H$

38. $R_{1}=c ; R_{2}=R_{3}=R_{4}=R_{5}=H ; R_{6}=G l c(1 \rightarrow 6) G l c ; R_{7}=R_{8}=H$

39. $\mathrm{R}_{1}=\mathrm{c} ; \mathrm{R}_{2}=\mathrm{R}_{3}=\mathrm{R}_{4}=\mathrm{H} ; \mathrm{R}_{5}=\mathrm{O} ; \mathrm{R}_{6}=\mathrm{Glc}(1 \rightarrow 6) \mathrm{Glc} ; \mathrm{R}_{7}=\mathrm{R}_{8}=\mathrm{H}$

40. $\mathrm{R}_{1}=\mathrm{j} ; \mathrm{R}_{2}=\mathrm{R}_{3}=\mathrm{R}_{4}=\mathrm{R}_{5}=\mathrm{H} ; \mathrm{R}_{6}=\mathrm{d} ; \mathrm{R}_{7}=\mathrm{R}_{8}=\mathrm{H}$

41. $\mathrm{R}_{1}=\mathrm{Glc}(1 \rightarrow 6) \mathrm{Glc} ; \mathrm{R}_{2}=\mathrm{R}_{3}=\mathrm{CH}_{3} ; \mathrm{R}_{4}=\mathrm{H} ; \mathrm{R}_{5}=\mathrm{O} ; \mathrm{R}_{6}=\mathrm{i} ; \mathrm{R}_{7}=\mathrm{R}_{8}=\mathrm{H}$

42. $\mathrm{R}_{1}=\mathrm{i} ; \mathrm{R}_{2}=\mathrm{R}_{3}=\mathrm{CH}_{3} \cdot \mathrm{R}_{4}=\mathrm{H} ; \mathrm{R}_{5}=\mathrm{O} ; \mathrm{R}_{6}=\mathrm{i} ; \mathrm{R}_{7}=\mathrm{R}_{8}=\mathrm{H}$

43. $\mathrm{R}_{1}=\mathrm{Glc}(1 \rightarrow 6) \mathrm{Glc} ; \mathrm{R}_{2}=\mathrm{R}_{3}=\mathrm{CH}_{3} ; \mathrm{R}_{4}=\mathrm{R}_{5}=\mathrm{H} ; \mathrm{R}_{6}=\mathrm{Glc}(1 \rightarrow 6) \mathrm{Glc} ; \mathrm{R}_{7}=\mathrm{R}_{8}=\mathrm{H}$

44. $\mathrm{R}_{1}=\mathrm{j} ; \mathrm{R}_{2}=\mathrm{R}_{3}=\mathrm{CH}_{3} ; \mathrm{R}_{4}=\mathrm{H} ; \mathrm{R}_{5}=\mathrm{O} ; \mathrm{R}_{6}=\mathrm{Glc}(1 \rightarrow 6) \mathrm{Glc} ; \mathrm{R}_{7}=\mathrm{R}_{8}=\mathrm{H}$

45. $\mathrm{R}_{1}=\mathrm{c} ; \mathrm{R}_{2}=\mathrm{R}_{3}=\mathrm{CH}_{3} ; \mathrm{R}_{4}=\mathrm{R}_{5}=\mathrm{H} ; \mathrm{R}_{6}=\mathrm{Glc}(2 \rightarrow 1) \mathrm{Rha} ; \mathrm{R}_{7}=\mathrm{R}_{8}=\mathrm{H}$

46. $\mathrm{R}_{1}=\mathrm{Glc}(1 \rightarrow 6) \mathrm{Glc} ; \mathrm{R}_{2}=\mathrm{R}_{3}=\mathrm{CH}_{3} ; \mathrm{R}_{4}=\mathrm{R}_{5}=\mathrm{H} ; \mathrm{R}_{6}=\mathrm{Glc}(1 \rightarrow 6)[\mathrm{Rha}(1 \rightarrow 2)-\mathrm{Glc}] \cdot \mathrm{R}_{7}=\mathrm{R}_{8}=\mathrm{H}$

47. $\mathrm{R}_{\mathrm{1}}=\mathrm{Glc} ; \mathrm{R}_{2}=\mathrm{R}_{3}=\mathrm{CH}_{3} \cdot \mathrm{R}_{4}=\mathrm{R}_{5}=\mathrm{R}_{6}=\mathrm{R}_{7}=\mathrm{R}_{8}=\mathrm{H}$

48. $\mathrm{R}_{1}=\mathrm{H} ; \mathrm{R}_{2}=\mathrm{R}_{3}=\mathrm{CH}_{3} ; \mathrm{R}_{4}=\mathrm{H} ; \mathrm{R}_{5}=\mathrm{OAc} ; \mathrm{R}_{6}=\mathrm{H} ; \mathrm{R}_{7}=\mathrm{h} ; \mathrm{R}_{8}=\mathrm{H}$

49. $\mathrm{R}_{1}=\mathrm{H} ; \mathrm{R}_{2}=\mathrm{R}_{3}=\mathrm{CH}_{3} ; \mathrm{R}_{4}=\mathrm{H} ; \mathrm{R}_{5}=\mathrm{OAc} ; \mathrm{R}_{6}=\mathrm{H} ; \mathrm{R}_{7}=3^{\prime}, 4^{\prime}$-di-O-Ang-Fuc; $\mathrm{R}_{8}=\mathrm{H}$

50. $\mathrm{R}_{1}=\mathrm{H} ; \mathrm{R}_{2}=\mathrm{R}_{3}=\mathrm{CH}_{3} ; \mathrm{R}_{4}=\mathrm{R}_{5}=\mathrm{H} ; \mathrm{R}_{6}=\mathrm{Glc} ; \mathrm{R}_{7}=\mathrm{R}_{8}=\mathrm{H}$

51. $\mathrm{R}_{1}=\mathrm{Glc} ; \mathrm{R}_{2}=\mathrm{R}_{3}=\mathrm{CH}_{3} ; \mathrm{R}_{4}=\mathrm{R}_{5}=\mathrm{H} ; \mathrm{R}_{6}=\mathrm{Glc}(1 \rightarrow 6) \mathrm{Glc} ; \mathrm{R}_{7}=\mathrm{R}_{8}=\mathrm{H}$

52. $\mathrm{R}_{1}=\mathrm{Glc} ; \mathrm{R}_{2}=\mathrm{R}_{3}=\mathrm{R}_{4}=\mathrm{R}_{5}=\mathrm{H} ; \mathrm{R}_{6}=\mathrm{Glc}(1 \rightarrow 2) \mathrm{Glc} ; \mathrm{R}_{7}=\mathrm{R}_{8}=\mathrm{H}$

53. $\mathrm{R}_{1}=\mathrm{Glc} ; \mathrm{R}_{2}=\mathrm{R}_{3}=\mathrm{R}_{4}=\mathrm{R}_{5}=\mathrm{H} ; \mathrm{R}_{6}=\mathrm{Rha}(1 \rightarrow 2)-\mathrm{Glc} ; \mathrm{R}_{7}=\mathrm{R}_{8}=\mathrm{H}$

54. $\mathrm{R}_{1}=\mathrm{b} ; \mathrm{R}_{2}=\mathrm{R}_{3}=\mathrm{R}_{4}=\mathrm{R}_{5}=\mathrm{H} ; \mathrm{R}_{6}=\mathrm{i} ; \mathrm{R}_{7}=\mathrm{R}_{8}=\mathrm{H}$

55. $\mathrm{R}_{1}=$ Glc $(1 \rightarrow 6)$-Glc $\left(2^{\prime}-\mathrm{Ang}\right) ; \mathrm{R}_{2}=\mathrm{R}_{3}=\mathrm{CH}_{3} ; \mathrm{R}_{4}=\mathrm{R}_{5}=\mathrm{H} ; \mathrm{R}_{6}=\mathrm{Glc}(1 \rightarrow 6)[\mathrm{Rha}(1 \rightarrow 2)-\mathrm{Glc}] ; \mathrm{R}_{7}=\mathrm{R}_{8}=\mathrm{H}$

56. $\mathrm{R}_{1}=\mathrm{Glc}(1 \rightarrow 6)-\mathrm{Glc} ; \mathrm{R}_{2}=\mathrm{R}_{3}=\mathrm{CH}_{3} ; \mathrm{R}_{4}=\mathrm{R}_{5}=\mathrm{H} ; \mathrm{R}_{6}=\mathrm{Rha}(1 \rightarrow 2)-\mathrm{Glc} ; \mathrm{R}_{7}=\mathrm{R}_{8}=\mathrm{H}$

57. $\mathrm{R}_{1}=\mathrm{Glc}(1 \rightarrow 6)$-Glc $\left(3^{\prime}-\mathrm{Ang}\right) ; \mathrm{R}_{2}=\mathrm{R}_{3}=\mathrm{CH}_{3} ; \mathrm{R}_{4}=\mathrm{R}_{5}=\mathrm{H} ; \mathrm{R}_{6}=\mathrm{Glc}(1 \rightarrow 6)[\mathrm{Rha}(1 \rightarrow 2)]-\mathrm{Glc} ; \mathrm{R}_{7}=\mathrm{R}_{8}=\mathrm{H}$

108. $\mathrm{R}_{1}=\mathrm{e} ; \mathrm{R}_{2}=\mathrm{R}_{3}=\mathrm{CH}_{3} ; \mathrm{R}_{4}=\mathrm{R}_{5}=\mathrm{OH} ; \mathrm{R}_{6}=\mathrm{H} ; \mathrm{R}_{7}=\mathrm{Ang} ; \mathrm{R}_{8}=\mathrm{q}$

109. $\mathrm{R}_{1}=\mathrm{Glc} ; \mathrm{R}_{2}=\mathrm{R}_{3}=\mathrm{CH}_{3} ; \mathrm{R}_{4}=\mathrm{R}_{5}=\mathrm{OH} ; \mathrm{R}_{6}=\mathrm{H} ; \mathrm{R}_{7}=\mathrm{R}_{8}=$ Ang

110. $\mathrm{R}_{1}=6$-O-methyl-GluA; $\mathrm{R}_{2}=\mathrm{R}_{3}=\mathrm{CH}_{3} ; \mathrm{R}_{4}=\mathrm{R}_{5}=\mathrm{OH} ; \mathrm{R}_{6}=\mathrm{H} ; \mathrm{R}_{7}=\mathrm{Ang} ; \mathrm{R}_{8}=$ isobutyryl

115. $\mathrm{R}_{1}=\mathrm{H} ; \mathrm{R}_{2}=\mathrm{R}_{3}=\mathrm{CH}_{3} ; \mathrm{R}_{4}=\mathrm{R}_{5}=\mathrm{OH} ; \mathrm{R}_{6}=\mathrm{H} ; \mathrm{R}_{7}=$ Fuc-Ang; $\mathrm{R}_{8}=\mathrm{H}$

116. $\mathrm{R}_{\mathrm{l}}=\mathrm{GluA} ; \mathrm{R}_{2}=\mathrm{R}_{3}=\mathrm{CH}_{3} \cdot \mathrm{R}_{4}=\mathrm{R}_{5}=\mathrm{OH} ; \mathrm{R}_{6}=\mathrm{H} ; \mathrm{R}_{7}=\mathrm{R}_{8}=\mathrm{Ang}$

117. $\mathrm{R}_{1}=\mathrm{H} ; \mathrm{R}_{2}=\mathrm{R}_{3}=\mathrm{CH}_{3} ; \mathrm{R}_{4}=\mathrm{R}_{5}=\mathrm{OH} ; \mathrm{R}_{6}=\mathrm{H} ; \mathrm{R}_{7}=$ epoxyangeloyl $; \mathrm{R}_{8}=\mathrm{Ang}$

118. $\mathrm{R}_{1}=\mathrm{H} ; \mathrm{R}_{2}=\mathrm{R}_{3}=\mathrm{CH}_{3} ; \mathrm{R}_{4}=\mathrm{R}_{5}=\mathrm{OH} ; \mathrm{R}_{6}=\mathrm{H} ; \mathrm{R}_{7}=2$, 3-dihydroxy-2-methylbutyryl; $\mathrm{R}_{8}=A n$

119. $\mathrm{R}_{1}=\mathrm{H} ; \mathrm{R}_{2}=\mathrm{R}_{3}=\mathrm{CH}_{3} ; \mathrm{R}_{4}=\mathrm{R}_{5}=\mathrm{OH} ; \mathrm{R}_{6}=$ isobutyryl; $\mathrm{R}_{7}=\mathrm{Ang} ; \mathrm{R}_{8}=\mathrm{H}$

120. $\mathrm{R}_{1}=6$-O-methyl-GluA; $\mathrm{R}_{2}=\mathrm{R}_{3}=\mathrm{CH}_{3} \cdot \mathrm{R}_{4}=\mathrm{R}_{5}=\mathrm{OH} ; \mathrm{R}_{6}=\mathrm{H} ; \mathrm{R}_{7}=\mathrm{Ang} ; \mathrm{R}_{8}=\mathrm{H}$

121. $\mathrm{R}_{1}=6$-O-methyl-GluA; $\mathrm{R}_{2}=\mathrm{R}_{3}=\mathrm{CH}_{3} \cdot \mathrm{R}_{4}=\mathrm{R}_{5}=\mathrm{OH} ; \mathrm{R}_{6}=\mathrm{H} ; \mathrm{R}_{7}=$ Ang; $\mathrm{R}_{8}=$ isobutyryl

122. $\mathrm{R}_{1}=6$-O-methyl-GluA; $\mathrm{R}_{2}=\mathrm{R}_{3}=\mathrm{CH}_{3} ; \mathrm{R}_{4}=\mathrm{R}_{5}=\mathrm{OH} ; \mathrm{R}_{6}=\mathrm{H} ; \mathrm{R}_{7}=\mathrm{R}_{8}=$ Ang



(n)



isobutyryl=

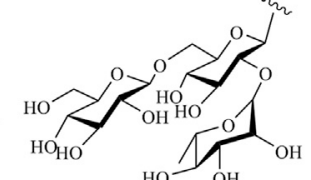

$\mathrm{HO} \mathrm{OH}$


$\mathrm{OH}$

FIGURE 2 | Structures of triterpenoids in X. sorbifolium.

chromatography (TLC), ${ }^{1} \mathrm{H}-\mathrm{NMR},{ }^{13} \mathrm{C}-\mathrm{NMR}$, and MS (Wu, 2017). The chemical structures of flavonoids are provided in Figure 3.

\section{Phenylpropanoids}

Phenylpropanoids are natural compounds with benzene rings. Phenylpropanoids generally contain a phenol structure and are a 




58. $\mathrm{R}_{1}=\mathrm{H} ; \mathrm{R}_{2}=\mathrm{R}_{3}=\mathrm{CH}_{3} ; \mathrm{R}_{4}=\mathrm{Glc} ; \mathrm{R}_{5}=\mathrm{R}_{6}=\mathrm{H}$ 59. $\mathrm{R}_{1}=\mathrm{Glc}(1 \rightarrow 6)$-Glc $\left(3^{\prime}-\mathrm{Ang}\right) ; \mathrm{R}_{2}=\mathrm{R}_{3}=\mathrm{CH}_{3} ; \mathrm{R}_{4}=\mathrm{Rha}(1 \rightarrow 2)-\mathrm{Glc} ; \mathrm{R}_{5}=\mathrm{R}_{6}=\mathrm{H}$ 60. $\mathrm{R}_{1}=\mathrm{Glc}(1 \rightarrow 6)[\mathrm{Glc}(1 \rightarrow 2)]-\mathrm{Glc} ; \mathrm{R}_{2}=\mathrm{R}_{3}=\mathrm{CH}_{3} ; \mathrm{R}_{4}=\mathrm{Glc}(1 \rightarrow 6)[\mathrm{Rha}(1 \rightarrow 2)]-\mathrm{Glc} ; \mathrm{R}_{5}=\mathrm{R}_{6}=\mathrm{H}$ 61. $\mathrm{R}_{1}=\mathrm{Glc}(1 \rightarrow 6)[\mathrm{Glc}(1 \rightarrow 2)]-\mathrm{Glc} ; \mathrm{R}_{2}=\mathrm{R}_{3}=\mathrm{CH}_{3} ; \mathrm{R}_{4}=\mathrm{Glc}(1 \rightarrow 6) \mathrm{Glc} ; \mathrm{R}_{5}=\mathrm{R}_{6}=\mathrm{H}$ 62. $\mathrm{R}_{1}=\mathrm{d} ; \mathrm{R}_{2}=\mathrm{R}_{3}=\mathrm{CH}_{3} ; \mathrm{R}_{4}=\mathrm{i} ; \mathrm{R}_{5}=\mathrm{OAc} ; \mathrm{R}_{6}=\mathrm{H}$ 63. $\mathrm{R}_{1}=\mathrm{Glc} ; \mathrm{R}_{2}=\mathrm{R}_{3}=\mathrm{CH}_{3} ; \mathrm{R}_{4}=\mathrm{k} ; \mathrm{R}_{5}=\mathrm{R}_{6}=\mathrm{H}$ 64. $\mathrm{R}_{1}=$ Glc-Ang; $\mathrm{R}_{2}=\mathrm{R}_{3}=\mathrm{CH}_{3} ; \mathrm{R}_{4}=\mathrm{i} ; \mathrm{R}_{5}=\mathrm{R}_{6}=\mathrm{H}$ 65. $\mathrm{R}_{1}=$ Glc-Ang; $\mathrm{R}_{2}=\mathrm{R}_{3}=\mathrm{CH}_{3} ; \mathrm{R}_{4}=\mathrm{k} ; \mathrm{R}_{5}=\mathrm{R}_{6}=\mathrm{H}$ 66. $\mathrm{R}_{1}=\mathrm{b} ; \mathrm{R}_{2}=\mathrm{R}_{3}=\mathrm{CH}_{3} ; \mathrm{R}_{4}=\mathrm{Rha}(1 \rightarrow 2) \mathrm{Glc} ; \mathrm{R}_{5}=\mathrm{R}_{6}=\mathrm{H}$ 67. $\mathrm{R}_{1}=\mathrm{Glc}(1 \rightarrow 6)-\mathrm{Glc} ; \mathrm{R}_{2}=\mathrm{R}_{3}=\mathrm{CH}_{3} ; \mathrm{R}_{4}=\mathrm{i} ; \mathrm{R}_{5}=\mathrm{R}_{6}=\mathrm{H}$ 68. $\mathrm{R}_{1}=\mathrm{m} ; \mathrm{R}_{2}=\mathrm{R}_{3}=\mathrm{CH}_{3} ; \mathrm{R}_{4}=\mathrm{i} ; \mathrm{R}_{5}=\mathrm{R}_{6}=\mathrm{H}$ 69. $\mathrm{R}_{\mathbf{1}}=\mathrm{n} ; \mathrm{R}_{2}=\mathrm{R}_{3}=\mathrm{CH}_{3} ; \mathrm{R}_{4}=\mathrm{i} ; \mathrm{R}_{5}=\mathrm{R}_{6}=\mathrm{H}$ 111. $\mathrm{R}_{1}=\mathrm{c} ; \mathrm{R}_{2}=\mathrm{R}_{3}=\mathrm{CH}_{3} ; \mathrm{R}_{4}=\mathrm{k} ; \mathrm{R}_{5}=\mathrm{H} ; \mathrm{R}_{6}=\mathrm{Ac}$ 112. $\mathrm{R}_{1}=\mathrm{j} ; \mathrm{R}_{2}=\mathrm{R}_{3}=\mathrm{CH}_{3} ; \mathrm{R}_{4}=\mathrm{k} ; \mathrm{R}_{5}=\mathrm{H} ; \mathrm{R}_{6}=\mathrm{Ac}$ 113. $\mathrm{R}_{1}=\mathrm{l} ; \mathrm{R}_{2}=\mathrm{R}_{3}=\mathrm{CH}_{3} ; \mathrm{R}_{4}=\mathrm{k} ; \mathrm{R}_{5}=\mathrm{H} ; \mathrm{R}_{6}=\mathrm{Ac}$ 124. $\mathrm{R}_{1}=\mathrm{b} ; \mathrm{R}_{2}=\mathrm{R}_{3}=\mathrm{CH}_{3} ; \mathrm{R}_{4}=\mathrm{i} ; \mathrm{R}_{5}=\mathrm{H} ; \mathrm{R}_{6}=\mathrm{Ac}$

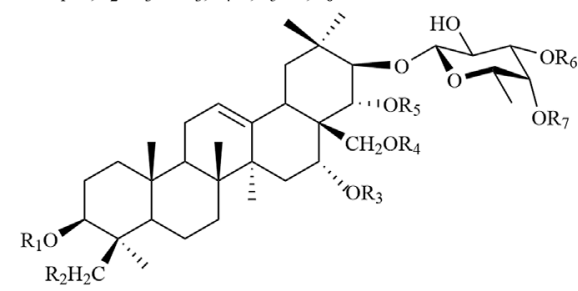

76. $\mathrm{R}_{1}=\mathrm{H} ; \mathrm{R}_{2}=\mathrm{OH} ; \mathrm{R}_{3}=\mathrm{R}_{4}=\mathrm{R}_{5}=\mathrm{H} ; \mathrm{R}_{6}=\mathrm{R}_{7}=\mathrm{Ang}$ 77. $\mathrm{R}_{1}=\mathrm{GlcU} A ; \mathrm{R}_{2}=\mathrm{OH} ; \mathrm{R}_{3}=\mathrm{R}_{4}=\mathrm{H} ; \mathrm{R}_{5}=\mathrm{Ac} ; \mathrm{R}_{6}=\mathrm{R}_{7}=$ Ang 78. $\mathrm{R}_{1}=\mathrm{R}_{2}=\mathrm{R}_{3}=\mathrm{R}_{4}=\mathrm{R}_{5}=\mathrm{H} ; \mathrm{R}_{6}=\mathrm{R}_{7}=$ Ang

79. $\mathrm{R}_{1}=\mathrm{R}_{2}=\mathrm{R}_{3}=\mathrm{R}_{4}=\mathrm{R}_{5}=\mathrm{H} ; \mathrm{R}_{6}=\mathrm{Ang} ; \mathrm{R}_{7}=\mathrm{Ac}$ 80. $\mathrm{R}_{1}=\mathrm{H} ; \mathrm{R}_{2}=\mathrm{OH} ; \mathrm{R}_{3}=\mathrm{R}_{4}=\mathrm{H} ; \mathrm{R}_{5}=\mathrm{Ac} ; \mathrm{R}_{6}=\mathrm{Ang} ; \mathrm{R}_{7}=\mathrm{Ac}$ 85. $\mathrm{R}_{1}=\mathrm{Glc}(1 \rightarrow 2) \mathrm{GlcUA} ; \mathrm{R}_{2}=\mathrm{OH} ; \mathrm{R}_{3}=\mathrm{R}_{4}=\mathrm{H} ; \mathrm{R}_{5}=\mathrm{Ac} ; \mathrm{R}_{6}=\mathrm{Ang} ; \mathrm{R}_{7}=\mathrm{Ac}$ 86. $\mathrm{R}_{1}=\mathrm{Glc}(1 \rightarrow 2) \mathrm{GlcUA} ; \mathrm{R}_{2}=\mathrm{OH} ; \mathrm{R}_{3}=\mathrm{R}_{4}=\mathrm{H} ; \mathrm{R}_{5}=A c ; \mathrm{R}_{6}=A n g ; \mathrm{R}_{7}=$ Ang 87. $\mathrm{R}_{1}=\mathrm{Glc}(1 \rightarrow 2)$ GlcUA; $\mathrm{R}_{2}=\mathrm{OH} ; \mathrm{R}_{3}=\mathrm{H} ; \mathrm{R}_{4}=\mathrm{Ac} ; \mathrm{R}_{5}=\mathrm{H} ; \mathrm{R}_{6}=\mathrm{Ang} ; \mathrm{R}_{7}=\mathrm{Ac}$ 88. $\mathrm{R}_{1}=\mathrm{Glc}(1 \rightarrow 2) \mathrm{GlcUA} ; \mathrm{R}_{2}=\mathrm{OH} ; \mathrm{R}_{3}=\mathrm{H} ; \mathrm{R}_{4}=\mathrm{Ac} ; \mathrm{R}_{5}=\mathrm{H} ; \mathrm{R}_{6}=\mathrm{Ang} ; \mathrm{R}_{7}=\mathrm{Ang}$ 89. $\mathrm{R}_{1}=\mathrm{Glc}(1 \rightarrow 2) \mathrm{GlcUA} ; \mathrm{R}_{2}=\mathrm{R}_{3}=\mathrm{R}_{4}=\mathrm{H} ; \mathrm{R}_{5}=\mathrm{Ac} ; \mathrm{R}_{6}=A n ; ; \mathrm{R}_{7}=A$ ng 90. $\mathrm{R}_{1}=\mathrm{Glc}(1 \rightarrow 2) \mathrm{GlcUA} ; \mathrm{R}_{2}=\mathrm{OH} ; \mathrm{R}_{3}=\mathrm{H} ; \mathrm{R}_{4}=\mathrm{Ac} ; \mathrm{R}_{5}=\mathrm{H} ; \mathrm{R}_{6}=\mathrm{Ang} ; \mathrm{R}_{7}=$ Ang 91. $\mathrm{R}_{1}=\mathrm{H} ; \mathrm{R}_{2}=\mathrm{OH} ; \mathrm{R}_{3}=\mathrm{Ac} ; \mathrm{R}_{4}=\mathrm{R}_{5}=\mathrm{H} ; \mathrm{R}_{6}=\mathrm{R}_{7}=$ Ang 114. $\mathrm{R}_{1}=\mathrm{R}_{2}=\mathrm{R}_{3}=\mathrm{H} ; \mathrm{R}_{4}=\mathrm{Ac} ; \mathrm{R}_{5}=\mathrm{H} ; \mathrm{R}_{6}=\mathrm{R}_{7}=\mathrm{H}$ 123. $\mathrm{R}_{1}=6$-O-methyl-GluA; $\mathrm{R}_{2}=\mathrm{R}_{3}=\mathrm{R}_{4}=\mathrm{R}_{5}=\mathrm{H} ; \mathrm{R}_{6}=\mathrm{R}_{7}=$ Ang

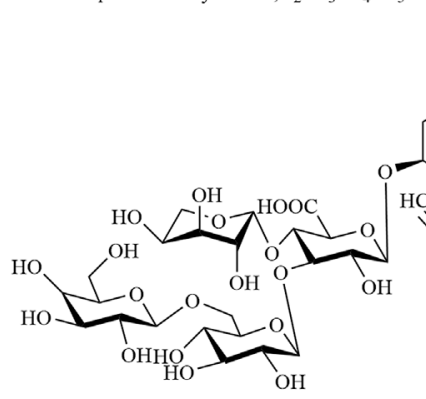
94

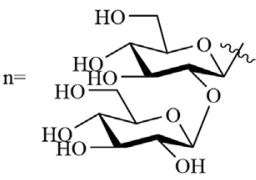
$\mathrm{HOH}_{2} \mathrm{C}$

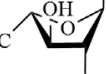
$\mathrm{o}=$



$\mathrm{OH}$

70. $\mathrm{R}_{1}=\mathrm{R}_{2}=\mathrm{R}_{3}=\mathrm{H} ; \mathrm{R}_{4}=\mathrm{Ac} ; \mathrm{R}_{5}=$ Fuc-Ang; $\mathrm{R}_{6}=\mathrm{Gal}$ 71. $\mathrm{R}_{1}=\mathrm{R}_{2}=\mathrm{H} ; \mathrm{R}_{3}=\mathrm{Ac} ; \mathrm{R}_{4}=\mathrm{H} ; \mathrm{R}_{5}=$ Fuc-Ang; $\mathrm{R}_{6}=\mathrm{Gal}$ 72. $\mathrm{R}_{1}=\mathrm{H} ; \mathrm{R}_{2}=\mathrm{OH} ; \mathrm{R}_{3}=\mathrm{H} ; \mathrm{R}_{4}=\mathrm{R}_{5}=\mathrm{Ang} ; \mathrm{R}_{6}=\mathrm{Gal}$ 73. $\mathrm{R}_{1}=\mathrm{H} ; \mathrm{R}_{2}=\mathrm{OH} ; \mathrm{R}_{3}=\mathrm{H} ; \mathrm{R}_{4}=\mathrm{q} ; \mathrm{R}_{5}=A n g ; \mathrm{R}_{6}=\mathrm{Gal}$ 74. $\mathrm{R}_{1}=\mathrm{OH} ; \mathrm{R}_{2}=\mathrm{OH} ; \mathrm{R}_{3}=\mathrm{H} ; \mathrm{R}_{4}=\mathrm{Ang} ; \mathrm{R}_{5}=\mathrm{Ang} ; \mathrm{R}_{6}=\mathrm{Glc}$ 75. $\mathrm{R}_{1}=\mathrm{R}_{2}=\mathrm{R}_{3}=\mathrm{H} ; \mathrm{R}_{4}=\mathrm{R}_{5}=\mathrm{Ang} ; \mathrm{R}_{6}=\mathrm{Gal}$



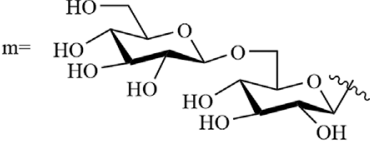<smiles>O</smiles>

$\mathrm{OOC}_{1}$<smiles>CCC(C)C(=O)[I-]</smiles><smiles>CCC</smiles>

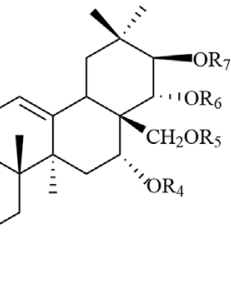

$\mathrm{OH}$

81. $\mathrm{R}_{\mathrm{l}}=\mathrm{n}-\mathrm{Bu} ; \mathrm{R}_{2}=\mathrm{Gal} ; \mathrm{R}_{3}=\mathrm{R}_{4}=\mathrm{R}_{5}=\mathrm{H} ; \mathrm{R}_{6}=\mathrm{Ang} ; \mathrm{R}_{7}=$ epoxyangeloyl 82. $\mathrm{R}_{1}=\mathrm{CH}_{3} ; \mathrm{R}_{2}=\mathrm{Gal} ; \mathrm{R}_{3}=\mathrm{H} ; \mathrm{R}_{4}=\mathrm{Ac} ; \mathrm{R}_{5}=\mathrm{H} ; \mathrm{R}_{6}=\mathrm{R}_{7}=A n g$ 83. $\mathrm{R}_{1}=\mathrm{CH}_{3} ; \mathrm{R}_{2}=\mathrm{Gal} ; \mathrm{R}_{3}=\mathrm{H} ; \mathrm{R}_{4}=\mathrm{H} ; \mathrm{R}_{5}=\mathrm{Ac} ; \mathrm{R}_{6}=\mathrm{H} ; \mathrm{R}_{7}=$ Fuc-Ang 84. $\mathrm{R}_{1}=\mathrm{CH}_{3} ; \mathrm{R}_{2}=\mathrm{Glc} ; \mathrm{R}_{3}=\mathrm{OH} ; \mathrm{R}_{4}=\mathrm{H} ; \mathrm{R}_{5}=\mathrm{H} ; \mathrm{R}_{6}=\mathrm{R}_{7}=$ Ang<smiles>C=CC=CC</smiles>

<smiles>CC(=O)/C=C/c1ccc(C)c(C)c1</smiles>

96. $\mathrm{R}_{1}=\mathrm{H} ; \mathrm{R}_{2}=\mathrm{O} ; \mathrm{R}_{3}=\mathrm{H} ; \mathrm{R}_{4}=\mathrm{COOH}$<smiles>CC(=O)/C=C/c1ccc(O)c(O)c1</smiles>
97. $\mathrm{R}_{1}=\mathrm{p} ; \mathrm{R}_{2}=\mathrm{OH} ; \mathrm{R}_{3}=\mathrm{H} ; \mathrm{R}_{4}=\mathrm{COOH}$ 98. $\mathrm{R}_{1}=\mathrm{R}_{2}=\mathrm{R}_{3}=\mathrm{H} ; \mathrm{R}_{4}=\mathrm{CH}_{2} \mathrm{OH}$

99. $\mathrm{R}_{1}=\mathrm{H} \cdot \mathrm{R}_{2}=\mathrm{H} \cdot \mathrm{R}_{3}=\mathrm{OH} \cdot \mathrm{R}_{4}=\mathrm{COOH}$

FIGURE 2 | (Continued).

phenolic substance. Fourteen simple phenylpropanoids have been extracted from $X$. sorbifolium, with their main components being coumarins (compounds

173-181,

185-186) and lignans (compounds 182-184). Zhu et al. (2018) isolated and purified the chemical composition of seed oil residue of $X$. sorbifolium by silicone, macroporous, Sephadex LH-20, and ODS column 


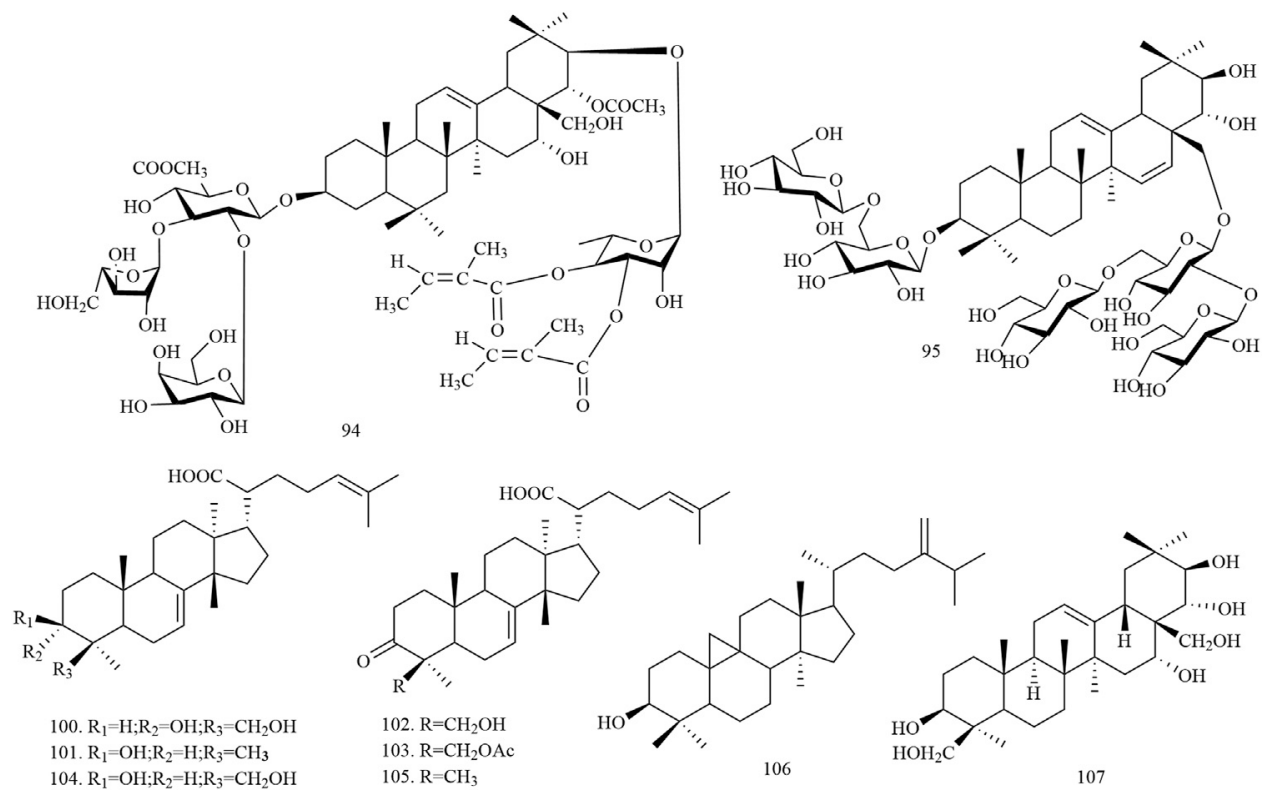

FIGURE 2 | (Continued).

chromatography. Four phenylpropanoid compounds, namely fraxin (173), fraxetin-7-O- $\beta$-D-[6'-( $3^{\prime \prime}$-hydroxyl- $3^{\prime \prime \prime}$ - methylglutaryl $\left.)\right]$ glucopyranoside (177), scopoletin (178), and esculetin (180) were identified by spectral and chemical methods (Zhu et al., 2018). The chemical structures of the phenylpropanoids are provided in Figure 4.

\section{Steroids}

Steroids are present in almost all plants and exhibit significant biological activity. Phytosterol is a steroid derivative of the $\mathrm{C}_{17}$ side chain with 8-10 carbon atoms in the side chain. At present, 17 steroids (compounds 187-203) have been reported from the wood, husks, carpophores, seed oil residue, and kernel oil of $X$. sorbifolium. Yan et al. (1984) used TLC, impregnated silica gel G with $18 \%$ silver nitrate, and separated kernel oil of $X$. sorbifolium with petroleum ether $(7: 3, \mathrm{~V} / \mathrm{V})$ as the developing agent. The steroid compounds $\beta$-sitosterol acetate (200), campesterol (201), campesterol acetate (202), and cholesterol (203) were identified by TLC, MS, FT-IR, and GC-MS (Yan et al., 1984). Cheng et al. (2001) separated the husk of $X$. sorbifolium by column chromatography and spectroscopy to obtain two steroids $(3 \beta, 5 \alpha, 20 R, 24 S)$-stigmasta-7,trans-22-dien-3-ol (189) and $(3 \beta, 5 \alpha, 20 R, 24 S)$-stigmasta-7-en-3-ol (190) (Cheng et al., 2001). The chemical structures of the steroids are provided in Figure 5.

\section{Phenols}

Through this review, 17 phenolics (compounds 204-220) were found in X. sorbifolium. Wan et al. (2015) studied the chemical constituents of the husk of $X$. sorbifolium. They were isolated and purified by TLC, Sephadex LH-20 column, ODS column, and preparative HPLC. Two phenolic compounds, hydroquinone (216) and 4-hydroxybenzylcyanide (217) were identified based on physicochemical properties and spectral data (Wan et al.,
2015). Wu (2017) separated and purified the acetone extract of lignum xanthocerais by ODS, Sephadex LH-20, and preparative HPLC. After that, two phenolic compounds, protocatechuic acid (209) and isochlorogenic acid B (210), were identified by TLC, ${ }^{1} \mathrm{H}-\mathrm{NMR},{ }^{13} \mathrm{C}-\mathrm{NMR}$, and MS (Wu, 2017). The chemical structures of the phenolic compounds are provided in Figure 6.

\section{Fatty Acids}

The fatty acid components are concentrated in the kernels and husks of $X$. sorbifolium. At present, 29 kinds of fatty acids (compounds 221-249) have been identified. Cheng et al. (2002) used GC-MS to separate and identify seven fatty acid compounds from the husk of $X$. sorbifolium, which were hexanoic acid (239), heptanoic acid (240), nonanoic acid (241), decanoic acid (242), 10methylundecanoic acid (243), 12-methyltetradecanoic acid (244) and heptadecanoic acid (245) (Cheng et al., 2002). The chemical structures of fatty acids are provided in Figure 7.

\section{Alkaloids}

Nine alkaloids (compounds 250-258) were obtained from the methanol extract of the seed and husks. Among these compounds, $\mathrm{Yu}$ et al. (2018) identified the chemical constituents of lignum xanthocerais by $1 \mathrm{D}$ - and 2D-NMR, and ESI-MS and obtained three alkaloid compounds, indole-3carboxaldehyde (251), allantoin (252), indole-3-acetylaspartic acid (253) ( $Y u$ et al., 2018). The chemical structures of alkaloids are provided in Figure 8.

\section{Quinones}

Four quinones (compounds 259-262) were also found in the fruits and wood of X. sorbifolium. Dong et al. (2008) used silica gel column, preparative TLC, and pharmadex LH-20 column chromatography to isolate compounds from the fruits of $X$. 
<smiles>[R3]c1cc(-c2oc3cc(Br)cc([R])c3c(=O)c2[R])cc([R])c1[R]</smiles>

125. $\mathrm{R}_{1}=\mathrm{H} ; \mathrm{R}_{2}=\mathrm{R}_{3}=\mathrm{R}_{4}=\mathrm{R}_{5}=\mathrm{OH} ; \mathrm{R}_{6}=\mathrm{H}$ 126. $\mathrm{R}_{1}=\mathrm{R}_{2}=\mathrm{R}_{3}=\mathrm{R}_{4}=\mathrm{R}_{5}=\mathrm{R}_{6}=\mathrm{OH}$ 127. $\mathrm{R}_{1}=\mathrm{R}_{2}=\mathrm{R}_{3}=\mathrm{OH}: \mathrm{R}_{4}=\mathrm{H}: \mathrm{R}_{5}=\mathrm{OH}: \mathrm{R}_{6}=\mathrm{H}$ 128. $\mathrm{R}_{1}=\mathrm{OH} ; \mathrm{R}_{2}=\mathrm{OH} ; \mathrm{R}_{3}=\mathrm{OCH}_{3} ; \mathrm{R}_{4}=\mathrm{H} ; \mathrm{R}_{5} \mathrm{OH} ; \mathrm{R}_{6}=\mathrm{H}$ 29. $\mathrm{R}_{1}=\mathrm{R}_{2}=\mathrm{R}_{3}=\mathrm{R}_{4}=\mathrm{OH} \cdot \mathrm{R}_{5}=\mathrm{OCH}_{3} ; \mathrm{R}_{6}=\mathrm{OH}$ 130. $\mathrm{R}_{1}=\mathrm{R}_{2}=\mathrm{OH} ; \mathrm{R}_{3}=\mathrm{OGlc} ; \mathrm{R}_{4}=\mathrm{R}_{5}=\mathrm{OH} ; \mathrm{R}_{6}=\mathrm{H}$ 131. $\mathrm{R}_{1}=\mathrm{ORha} ; \mathrm{R}_{2}=\mathrm{R}_{3}=\mathrm{R}_{4}=\mathrm{R}_{5}=\mathrm{OH} ; \mathrm{R}_{6}=\mathrm{H}$ 132. $\mathrm{R}_{1}=\mathrm{OGlc} ; \mathrm{R}_{2}=\mathrm{R}_{3}=\mathrm{R}_{4}=\mathrm{R}_{5}=\mathrm{R}_{6}=\mathrm{OH}$ 133. $\mathrm{R}_{1}=\mathrm{OCH}_{3}: \mathrm{R}_{2}=\mathrm{R}_{3}=\mathrm{R}_{4}=\mathrm{R}_{5}=\mathrm{OH} ; \mathrm{R}_{6}=\mathrm{H}$ 134. $\mathrm{R}_{1}=\mathrm{ORha} ; \mathrm{R}_{2}=\mathrm{R}_{3}=\mathrm{R}_{4}=\mathrm{R}_{5}=\mathrm{R}_{6}=\mathrm{OH}$ 135. $\mathrm{R}_{1}=\mathrm{OGlc}: \mathrm{R}_{2}=\mathrm{R}_{3}=\mathrm{R}_{4}=\mathrm{R}_{5}=\mathrm{R}_{6}=\mathrm{OH}$ 136. $\mathrm{R}_{1}=\mathrm{ORha} ; \mathrm{R}_{2}=\mathrm{R}_{3}=\mathrm{OH} ; \mathrm{R}_{4}=\mathrm{H} ; \mathrm{R}_{5}=\mathrm{OH} ; \mathrm{R}_{6}=\mathrm{OH}$ 137. $\mathrm{R}_{2}=\mathrm{OGlc} \cdot \mathrm{R}_{2}=\mathrm{R}_{3}=\mathrm{OH} \cdot \mathrm{R}_{\mathrm{R}}-\mathrm{H} \cdot \mathrm{R}_{5}=\mathrm{OH} \cdot \mathrm{R}_{6}=\mathrm{H}$ 138. $\mathrm{R}_{1}=\mathrm{Glc}(2 \rightarrow 1) \mathrm{Rha} ; \mathrm{R}_{2}=\mathrm{R}_{3}=\mathrm{OH} ; \mathrm{R}_{4}=\mathrm{H} ; \mathrm{R}_{5}=\mathrm{OH} ; \mathrm{R}_{6}=\mathrm{H}$ 139. $\mathrm{R}_{1}=\mathrm{Rha}(1 \rightarrow 6) \mathrm{GlcO} ; \mathrm{R}_{2}=\mathrm{R}_{3}=\mathrm{OH} ; \mathrm{R}_{4}=\mathrm{H} ; \mathrm{R}_{5}=\mathrm{OH} ; \mathrm{R}_{6}=\mathrm{H}$ 140. $\mathrm{R}_{1}=\mathrm{O}$-rutinose $; \mathrm{R}_{2}=\mathrm{R}_{3}=\mathrm{R}_{4}=\mathrm{R}_{5}=\mathrm{OH} ; \mathrm{R}_{6}=\mathrm{H}$ 141. $\mathrm{R}_{1}=\mathrm{H} ; \mathrm{R}_{2}=\mathrm{R}_{3}=\mathrm{OH} ; \mathrm{R}_{4}=\mathrm{OCH}_{3} ; \mathrm{R}_{5}=\mathrm{OH} ; \mathrm{R}_{6}=\mathrm{H}$ 142. $\mathrm{R}_{1}=\mathrm{H} ; \mathrm{R}_{2}=\mathrm{R}_{3}=\mathrm{R}_{4}=\mathrm{R}_{5}=\mathrm{OH} ; \mathrm{R}_{6}=\mathrm{H}$ 143. $\mathrm{R}_{1}=\mathrm{Rha}(1 \rightarrow 6) \mathrm{GlcO} ; \mathrm{R}_{2}=\mathrm{R}_{3}=\mathrm{R}_{4}=\mathrm{R}_{5}=\mathrm{R}_{6}=\mathrm{OH}$ 144. $\mathrm{R}_{1}=\mathrm{Rha}(1 \rightarrow 6) \mathrm{GlcO} ; \mathrm{R}_{2}=\mathrm{R}_{3}=\mathrm{OH} ; \mathrm{R}_{4}=\mathrm{OCH}_{3} ; \mathrm{R}_{5}=\mathrm{OH} ; \mathrm{R}_{6}=\mathrm{H}$ 145. $\mathrm{R}_{1}=\mathrm{H} ; \mathrm{R}_{2}=\mathrm{R}_{3}=\mathrm{R}_{4}=\mathrm{R}_{5}=\mathrm{OH} ; \mathrm{R}_{6}=\mathrm{H}$<smiles>[R3]c1cc(C2Oc3cc(O)cc(O)c3CC2O)cc(Br)c1O</smiles><smiles>[R9]c1cc([C@@H]2Oc3cc(O)cc(O)c3C[C@H]2O)cc(Br)c1O</smiles>

162. $\mathrm{R}_{1}=\mathrm{OH} ; \mathrm{R}_{2}=\mathrm{H}$ 163. $\mathrm{R}_{1}=\mathrm{OH} ; \mathrm{R}_{2}=\mathrm{OH}$ 164. $\mathrm{R}_{1}=\mathrm{OH} ; \mathrm{R}_{2}=\mathrm{R}_{3}=\mathrm{H}$ 165. $\mathrm{R}_{1}=\mathrm{R}_{2}=\mathrm{OH} ; \mathrm{R}_{3}=$ 166. $\mathrm{R}_{1}=\mathrm{R}_{2}=\mathrm{R}_{3}=\mathrm{H}$ 167. $\mathrm{R}_{1}=\mathrm{OH} ; \mathrm{R}_{2}=\mathrm{H} ; \mathrm{R}_{3}=\mathrm{Glc}$
146. $\mathrm{R}_{1}=\beta \mathrm{H} ; \mathrm{R}_{2}=\mathrm{R}_{3}=\mathrm{OH} ; \mathrm{R}_{4}=\mathrm{H} ; \mathrm{R}_{5}=\mathrm{OH}$ 147. $\mathrm{R}_{1}=\beta \mathrm{H} ; \mathrm{R}_{2}=\mathrm{R}_{3}=\mathrm{R}_{4}=\mathrm{R}_{5}=\mathrm{OH}$ 148. $\mathrm{R}_{1}=\beta \mathrm{H} ; \mathrm{R}_{2}=\mathrm{R}_{3}=\mathrm{R}_{4}=\mathrm{OH} ; \mathrm{R}_{5}=\mathrm{OGlc}$ 149. $\mathrm{R}_{1}=\alpha \mathrm{H} ; \mathrm{R}_{2}=\mathrm{OH} ; \mathrm{R}_{3}=\mathrm{OGlc} ; \mathrm{R}_{4}=\mathrm{R}_{5}=\mathrm{OH}$ 150. $\mathrm{R}_{1}=\beta \mathrm{H} ; \mathrm{R}_{2}=\mathrm{OH} ; \mathrm{R}_{3}=\mathrm{OGlc} ; \mathrm{R}_{4}=\mathrm{R}_{5}=\mathrm{OH}$ 151. $\mathrm{R}_{1}=\alpha \mathrm{H} ; \mathrm{R}_{2}=\mathrm{OGlc} ; \mathrm{R}_{3}=\mathrm{OH} ; \mathrm{R}_{4}=\mathrm{H} ; \mathrm{R}_{5}=\mathrm{OH}$ 152. $\mathrm{R}_{1}=\beta \mathrm{H} ; \mathrm{R}_{2}=\mathrm{OH} ; \mathrm{R}_{3}=\mathrm{OH} ; \mathrm{R}_{4}=\mathrm{H} ; \mathrm{R}_{5}=\mathrm{OGlc}$ 153. $\mathrm{R}_{1}=\beta \mathrm{H} ; \mathrm{R}_{2}=\mathrm{OGlc} ; \mathrm{R}_{3}=\mathrm{OH} ; \mathrm{R}_{4}=\mathrm{H} ; \mathrm{R}_{5}=\mathrm{OH}$<smiles>O=C1c2c(O)cc(O)cc2O[C@@H](c2ccc(O)c(O)c2)[C@@H]1O</smiles>
161<smiles>[R3]c1c(Br)cc(C2Oc3cc(OC)cc(O)c3C(=O)C2[R9])cc1Br</smiles>

154. $\mathrm{R}_{1}=\mathrm{H} ; \mathrm{R}_{2}=\mathrm{OH} ; \mathrm{R}_{3}=\mathrm{R}_{4}=\mathrm{H}$ 155. $\mathrm{R}_{1}=\mathrm{R}_{2}=\mathrm{R}_{3}=\mathrm{OH} ; \mathrm{R}_{4}=\mathrm{H}$ 156. $\mathrm{R}_{1}=\mathrm{R}_{2}=\mathrm{OH} ; \mathrm{R}_{3}=\mathrm{H} ; \mathrm{R}_{4}=\mathrm{OH}$ 157. $\mathrm{R}_{1}=\mathrm{OH} ; \mathrm{R}_{2}=\mathrm{H} ; \mathrm{R}_{3}=\mathrm{R}_{4}=\mathrm{OH}$ 158. $\mathrm{R}_{1}=\mathrm{H} ; \mathrm{R}_{2}=\mathrm{OH} ; \mathrm{R}_{3}=\mathrm{R}_{4}=\mathrm{OH}$ 159. $\mathrm{R}_{1}=\mathrm{OH} ; \mathrm{R}_{2}=\mathrm{OH} ; \mathrm{R}_{3}=\mathrm{R}_{4}=\mathrm{OH}$ 160. $\mathrm{R}_{1}=\mathrm{OH} ; \mathrm{R}_{2}=\mathrm{OH} ; \mathrm{R}_{3}=\mathrm{H} ; \mathrm{R}_{4}=\mathrm{OH}$

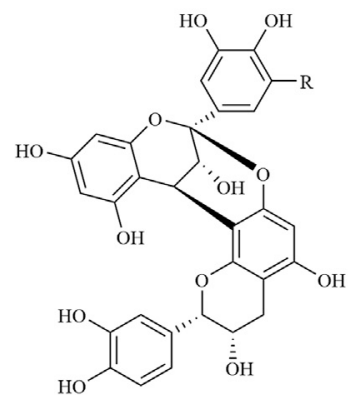

168. $\mathrm{R}=\mathrm{OH}$ 169. $\mathrm{R}=\mathrm{H}$<smiles></smiles>

170

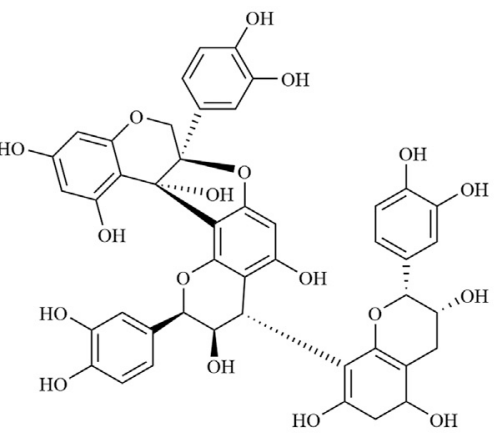

171<smiles>Oc1cc(O)c2c(c1)O[C@@]1(c3ccc(O)c(O)c3)O[C@@]1(O)[C@H](c1c(O)cc(O)c3c1O[C@H](c1ccc(O)c(O)c1)[C@H](O)C3)c1c(O)cc(O)cc1-2</smiles>

172

FIGURE 3 | Structures of flavonoids in X. sorbifolium.

sorbifolium and identified their structure by a spectral method. As a result, four quinone compounds were isolated: 2,5-dimethoxyp-benzoquinone (259), physicone (260), chrysophanol (261), and emodin (262) (Dong et al., 2008). The chemical structures of quinones are provided in Figure 9.

\section{Others}

In addition to the constituents mentioned previously, an additional sixteen compounds (263-278) were identified. Moreover, some nutritional elements were also found to be abundant in the herb. More than ten amino acids were found in the seeds of $X$. sorbifolium.
It is worth noting that the predominant amino acids present are glutamic plus glutamine, aspartic plus asparagine, and arginine. These amino acids account for up to $43 \%$ of the total amino acids present in the species (Fan et al., 2009; Mónica et al., 2017). The chemical structures of other compounds are provided in Figure 10.

\section{PHARMACOLOGICAL ACTIVITIES}

The pharmacological properties of $X$. sorbifolium have attracted a great deal of attention in recent years. The main pharmacological 
<smiles>[R20]c1cc2ccc(=O)oc2c([R20])c1[R6]</smiles><smiles>COc1c2occc2cc2ccc(=O)oc12</smiles>

181

173. $\mathrm{R}_{1}=\mathrm{CH}_{3} ; \mathrm{R}_{2}=\mathrm{OGlc} ; \mathrm{R}_{3}=\mathrm{H}$ 174. $\mathrm{R}_{1}=\mathrm{CH}_{3} \cdot \mathrm{R}_{2}=\mathrm{OH} \cdot \mathrm{R}_{3}=\mathrm{H}$ 175. $\mathrm{R}_{1}=\mathrm{CH}_{3} ; \mathrm{R}_{2}=\mathrm{CH}_{3} ; \mathrm{R}_{3}=\mathrm{H}$ 176. $\mathrm{R}_{1}=\mathrm{Glc} ; \mathrm{R}_{2}=\mathrm{H} ; \mathrm{R}_{3}=\mathrm{CH}_{3}$ 177. $\mathrm{R}_{1}=\mathrm{CH}_{3} ; \mathrm{R}_{2}=\mathrm{OH} ; \mathrm{R}_{3}=\mathrm{q}$ 178. $\mathrm{R}_{1}=\mathrm{CH}_{3} ; \mathrm{R}_{2}=\mathrm{H} ; \mathrm{R}_{3}=\mathrm{H}$ 179. $\mathrm{R}_{1}=\mathrm{H} ; \mathrm{R}_{2}=\mathrm{CH}_{3} ; \mathrm{R}_{3}=\mathrm{H}$ 180. $\mathrm{R}_{1}=\mathrm{R}_{2}=\mathrm{R}_{3}=\mathrm{H}$<smiles>O=c1ccc2ccc(O)cc2o1</smiles>

185<smiles>[R]c1cc([C@H]2Oc3c(c(OC)cc4ccc(=O)oc34)O[C@@H]2CO)cc(OC)c1O</smiles><smiles>OCC(CO)[C@@H](CO)Cc1ccc2c(c1)OCO2</smiles>

184

182. $\mathrm{R}=\mathrm{OCH}_{3}$ 183. $\mathrm{R}=\mathrm{H}$<smiles>COc1cc2cc(-c3cc4cc(OC)c(O)cc4oc3=O)c(=O)oc2cc1O</smiles>

186

FIGURE 4 | Structures of phenylpropanoids in X. sorbifolium.

activities of $X$. sorbifolium include improving learning and memory impairments, anti-inflammatory, anti-tumor, and anti-oxidation. In particular, the triterpene saponin xanthoceraside, a characteristic compound of $X$. sorbifolium, shows excellent learning and memory improvement, antiinflammatory, and anti-tumor activities. Table 2 lists some in vitro and in vivo pharmacological models and related dosage information to clarify the pharmacological activities of X. sorbifolium.

\section{Improving Learning and Memory Impairments}

Improving learning and memory impairments is mainly demonstrated through the regression of Alzheimer's disease $(\mathrm{AD}) . \mathrm{AD}$ is a neurodegenerative disease that exhibits relentless progression in cognition impairment and memory dysfunction. Its formation and development are closely associated with the neurotoxicity of extracellular amyloid-beta $(A \beta)$ deposits (Li et al., 2020). The specific mechanisms include the induction of apoptosis (Qu et al., 2000), activation of glial cells to induce inflammatory cascades (Li et al., 1998), triggering of oxidative stress (Huang et al., 1999), increase in intracellular $\mathrm{Ca}^{2+}$, and reduction of cell membrane fluidity (Tian et al., 2001). Among these, $\mathrm{A} \beta$-associated oxidative stress and related antioxidant defense system deficits are fundamental mechanisms in AD etiopathogenesis (Ma and Klann, 2012).

Previous studies indicate that barrigenol-type triterpenoids exhibit remarkable protective effects against spatial memory impairments. As such, they have the potential to be used in $\mathrm{AD}$ therapy and other neurodegenerative diseases. For instance, Qi et al. (2017) used an intracerebroventricular injection of amyloid 1-42 (A $\beta 1-42)$ to establish a mouse model to test the effect of xanthoceraside on $\mathrm{A} \beta$-induced cognitive dysfunction and the influence of the TLR2/NF- $\mathrm{B}$ and MAPK pathway. The results showed that xanthoceraside at doses of 0.08 and $0.32 \mathrm{mg} \mathrm{kg}^{-1}$ significantly improved learning and memory impairments in mice and significantly inhibited $A \beta 1-42$ induced overexpression of GFAP and CD11b. The results suggested that xanthoceraside inhibited the TLR2 pathway and downregulated MAPK and NF- $\mathrm{BB}$ activity, which may be associated with improved learning and memory impairment (Qi et al., 2017). Li et al. (2020) isolated 8 kinds of barrigenoltype triterpenoids, all of which firstly detected the oxidative stress effect of hydrogen peroxide on human SH-SY5Y cells. Then Y-maze, Morris water maze, new object recognition, and passive avoidance tests were used to evaluate the improvement effect of the selected compounds on ICV A $\beta 1-42$ mice. The compounds, $\quad\left(3-O-[\beta\right.$-D-glucopyranosyl $\quad(1 \rightarrow 6)] \quad\left(3^{\prime}\right.$ $O$-angeloyl)- $\beta$-D-glucopyranosyl and $28-O-[\beta-\mathrm{D}$ glucopyranosyl $(1 \rightarrow 6)]$-[ $\alpha$-L-rhamnopyranosyl $(1 \rightarrow 2)]-\beta$-Dglucopyranosyl 16-deoxybarring-togenol $\mathrm{C} \quad\left(0.32 \mathrm{mg} \mathrm{kg}^{-1}\right)$ showed significant improvements in enhancing memory disorders, object recognition defects, learning and memory impairments, and spatial memory disorders induced by $A \beta_{1-42}$ $(410 \mathrm{pmol}$ in $3 \mu \mathrm{L})$ in intracerebroventricular (ICV)-injected mice (Li et al., 2020).

Ji et al. (2017) reported that total triterpenoid saponins from $X$. sorbifolium husks significantly improves learning and memory impairments. Specifically, it significantly increased spontaneous alternation in the $\mathrm{Y}$ maze test and prolonged swimming duration in the fourth quadrant of the Morris water maze probe test at a dosage of $8.4 \mathrm{mg} \mathrm{kg}^{-1}$. This substance also improved escape latency and passive avoidance test results in a dose-dependent manner. The primary mechanism might be associated with its protective effects against oxidative stress damage, cholinergic system deficiency, and synaptic damage (Ji et al., 2017). A study conducted using a rat AD model with ICV injection of $\mathrm{A} \beta_{25-35}$ revealed that rats receiving $70 \%$ aqueous ethanol extracts containing husks of $X$. sorbifolium (5 and $10 \mathrm{mg} \mathrm{kg}^{-1}$ ) 
<smiles>CC(C)C(C)(C)CCC1CCC2C3=CCC4CC(=O)CCC4(C)C3CCC12C</smiles>

187<smiles>CCC(CC[C@@H](C)[C@H]1CC[C@H]2C3=CCC4CC(O)CC[C@]4(C)[C@H]3CC[C@]21C)C(C)C</smiles>

190

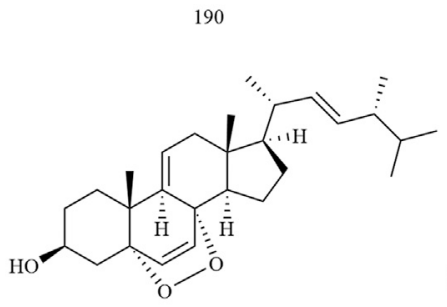

193<smiles>CCC(/C=C/[C@@H](C)[C@H]1CC[C@H]2[C@@H]3CCC4C=C(OC(C)=O)CC[C@]4(C)[C@H]3CC[C@@]21C)C(C)C</smiles>

188<smiles>CCC(/C=C/[C@@H](C)[C@H]1CCC2C3CC[C@H]4C[C@@H](O)CC[C@]4(C)[C@H]3CC[C@]2(C)[C@H]1C)C(C)C</smiles>

191

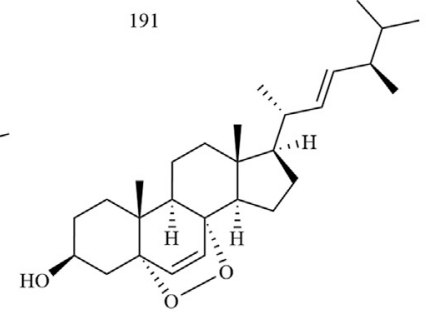

194



192<smiles>CCC(CC[C@@H](C)[C@H]1CC[C@H]2C3=CCC4CCCC(O)[C@]4(C)[C@@H]3CC[C@@]21C)C(C)C</smiles>

195

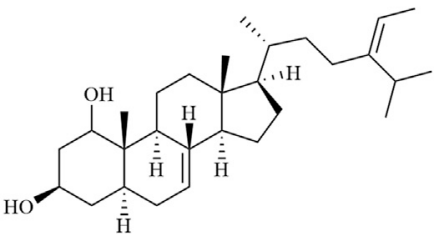

196

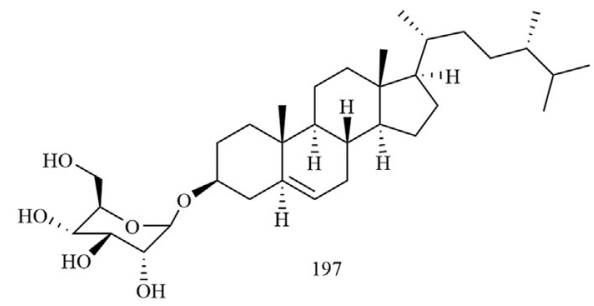<smiles>CCC(/C=C/[C@H](C)[C@H]1CC[C@H]2C3CC=C4C[C@@H](O)CC[C@]4(C)[C@H]3CC[C@]21C)C(C)C</smiles>

198

199<smiles>CC[C@H](CC[C@H](C)[C@H]1CC[C@H]2[C@@H]3CCC4C[C@@H](OC(C)=O)CC[C@]4(C)[C@H]3CC[C@]21C)C(C)C</smiles>

200<smiles>CC(C)C(C)CC[C@@H](C)[C@H]1CC[C@H]2[C@H]3CC=C4C[C@@H](O)CC[C@]4(C)[C@H]3CC[C@@]21C</smiles>

201



202

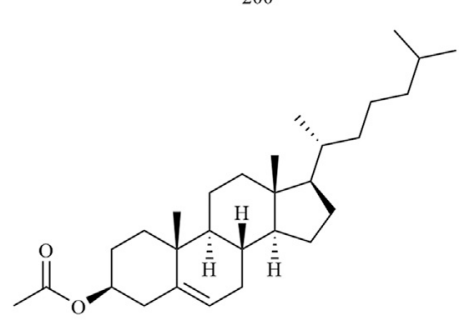

203

FIGURE 5 | Structures of steroids in X. sorbifolium.

demonstrated an upregulation of brain-derived neurotrophic factor (BDNF) expression, which protects the dendritic spine and achieves cognition-improving effects. The primary mechanism was a decrease in the dendritic spine density via activation of the BDNF/TrkB signaling pathway and inhibition of the RhoA/ROCK2 signaling pathway (Li Y. et al., 2016). In mice 
<smiles>Cc1cccc(O)c1C(=O)O</smiles><smiles>COc1cc(C(=O)O)ccc1O</smiles>
205<smiles>OC/C=C/C=C/c1ccc(O)c(O)c1</smiles><smiles>C1CCOCC1</smiles><smiles>O=C(O)c1cc(O)c(O)c(O)c1</smiles>

206



207<smiles>O=C(O)Cc1ccc(O)cc1</smiles>

208<smiles>O=C(O)c1ccc(O)c(O)c1</smiles><smiles>Cc1cc(O)cc(O)c1C(=O)OC[C@H](O)[C@@H](O)[C@H](O)[C@H](O)CO</smiles>

213

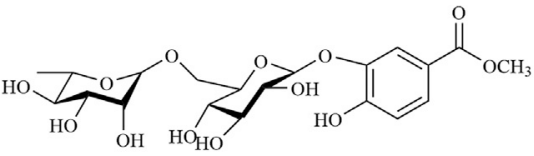

212<smiles>O=c1ccoc2cccc(O)c12</smiles>

218

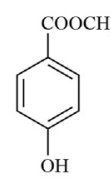

219
214<smiles>COC(=O)/C=C/c1ccc(O)c(O)c1</smiles>

220

FIGURE 6 | Structures of phenolic compounds in X. sorbifolium.

models impaired by scopolamine and sodium nitrite, ethanol extracts from the pericarp of X. sorbifolium $\left(89.80,44.90 \mathrm{mg} \mathrm{kg}^{-1}\right.$, i g), bunkanka saponins (1.51, $0.76 \mathrm{mg} \cdot \mathrm{kg}^{-1}, \mathrm{ig}$ ), and ST-n-2 (a saponin, $0.32,0.16 \mathrm{mg} \cdot \mathrm{kg}^{-1}$, i g) were found to notably improve memory acquisition after impairment induced by scopolamine and memory consolidation impairment induced by sodium nitrite. The mechanism may involve central cholinergic and glutamatergic nervous system functions and protection against damage caused by reactive oxygen species (ROS) in brain tissue.

In summary, the ability of $X$. sorbifolium to improve learning and memory impairment has been thoroughly studied, and the related active compounds and mechanisms have been revealed. Several studies reported on the signaling pathways that regulate and improve learning and memory impairment, indicating that this is an important pharmacological activity of $X$. sorbifolium. However, this pharmacological activity has not been widely applied in clinical research. Therefore, future research should focus on the practical application of this pharmacological activity to achieve a wide range of clinical applications and maximize the pharmacological value of this plant.

\section{Anti-Inflammatory Activity}

Anti-inflammatories are the second-largest class of drugs after antibacterial agents; thus, the anti-inflammatory effects of the active ingredients of Chinese herbal medicines have become a hot research topic (Li and Zhu, 2012; Rajendiran et al., 2018). The anti-inflammatory effect of $X$. sorbifolium has also been extensively studied, including the anti-inflammatory mechanism behind its traditional uses for rheumatism and scabies.
Current research has found that the extracts and compounds from $X$. sorbifolium mainly affect neuroinflammation, vascular inflammation, and rheumatoid arthritis. The flavonoids and phenylpropanoids isolated from the leaves of X. sorbifolium decreased nitric oxide (NO) production in the lipopolysaccharide-induced BV2 microglial cells. Among them, the inhibitory effect of 4-O- $\beta$-D-glucopyranosyl-trans$p$-coumaric acid $\left(\mathrm{IC}_{50}=9.08 \pm 1.23 \mu \mathrm{M}\right)$ on $\mathrm{NO}$ was significantly stronger than that of the positive control minocycline $\left(\mathrm{IC}_{50}=37.04 \pm 2.09 \mu \mathrm{M}\right)$ ( Li N. et al., 2016). Another report also indicated that a 70\% ethanol extract of $X$. sorbifolium husk is rich in effective anti-neuro-inflammatory active ingredients. Among them, the two triterpenoids $\left(\mathrm{IC}_{50}\right.$ values of $5.01 \pm 0.22$ and $3.05 \pm 1.21 \mu \mathrm{M})$ and the two alkaloids $\left(\mathrm{IC}_{50}\right.$ values of $9.61 \pm 0.21$ and $\left.4.72 \pm 0.52 \mu \mathrm{M}\right)$ were significantly stronger than the positive drug minocycline $\left(\mathrm{IC}_{50}=\right.$ $30.31 \pm 3.01 \mu \mathrm{M})$ (Chen et al., 2020a). The ethanol extract from $X$. sorbifolium seeds $\left(1-50 \mu \mathrm{g} \mathrm{m}^{-1}\right)$ has significant implications for the prevention of vascular complications, which is linked to inhibition of the NF- $\mathrm{kB} /$ reactive oxygen species (ROS) pathway and activation of the Nrf-2/HO-1 pathway (Jung Joo et al., 2018). Xanthoceraside (extracted from the husk of $X$. sorbifolium) significantly inhibits the release of NO, IL- $1 \beta$, and TNF- $\alpha$ in a concentration ( 0.01 and $0.1 \mu \mathrm{M})$-dependent manner (Qi et al., 2013). In addition, gavage with n-butanol extract (2,000 $\mathrm{mg} \mathrm{kg}^{-1}$; from $X$. sorbifolium wood) has shown a significant inhibitory effect on ear swelling induced by xylene $\left(25 \mu \mathrm{L} \cdot \mathrm{ear}^{-1}\right)$ in Chinese Kunming (KM) mice, indicating that n-butanol extracts in $X$. sorbifolium wood can inhibit the early exudation and edema caused by inflammation (Kuang et al., 2001). Similarly, 7 days of gavage with the 


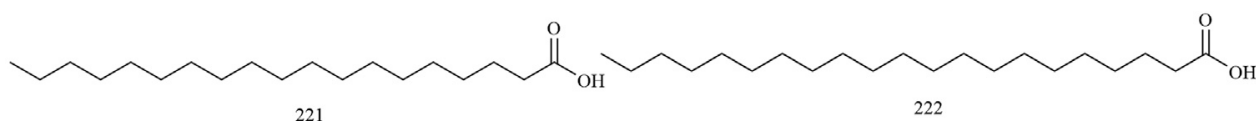

22

222<smiles>CCCCCCCCCCCCCCCCCCCCCCC(C)=O</smiles>

223<smiles>CCCCCC/C=C/CCCCCCCC(=O)O</smiles>

225<smiles>CCCCC=CCCC=CCCCCCCCCCCCC(=O)O</smiles>

227<smiles>CCCCCCCC/C=C/CCCCCCCCCCCCCC(=O)O</smiles>

229<smiles>CCCCCCCC/C=C/CCCCCCCC(=O)O</smiles><smiles>CCCCCCCC/C=C/CCCCCCCCCCCC(=O)O</smiles>

231<smiles>CCCCCCCCCCCCCCC/C=C/C=C/C(=O)O</smiles>

233<smiles>CCCCCCCCCCCCCCCCCCCC(=O)O</smiles>

235<smiles>CCCCCCCCCCCCCCCCCCCCCCCC(=O)O</smiles>

236<smiles>CCCCCCCCCCCCCCCCCCCCCC(=O)O</smiles>

237<smiles>CCCCCCCCCCCC(=O)O</smiles>

238

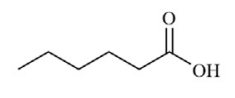

239<smiles>CCCCCCC(=O)O</smiles><smiles>CCCCCCCCC(=O)O</smiles>

241<smiles>CC(C)CCCCCCCCC(=O)O</smiles>

243

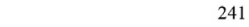<smiles>CCC(C)CCCCCCCCCCC(=O)O</smiles>

244<smiles>CCCCCCCCCCCCCCCCC(=O)O</smiles>

245<smiles>CCCCC/C=C/C/C=C/CCCCCCCC(=O)O</smiles><smiles>CCCCCCCC/C=C/CCCCCCCC(=O)O</smiles>

247<smiles>CCCCCCCC/C=C/CCCCCCCCCC(=O)O</smiles>

249

FIGURE 7 | Structures of fatty acid compounds in X. sorbifolium. 
<smiles>Cc1cncc(CC(O)C(O)CO)n1</smiles><smiles>O=Cc1c[nH]c2ccccc12</smiles>

250

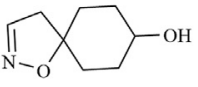

254

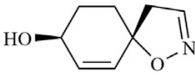<smiles>NC(=O)NC1NC(=O)NC1=O</smiles>

252

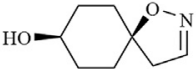

256

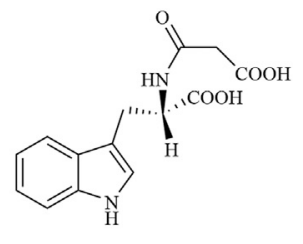

253<smiles>[AlH2]C1C=CC2(C=C1)CC=NO2</smiles>

25<smiles>COC1=CC(=O)C(OC)=CC1=O</smiles>

259<smiles>[R1]c1cc(O)c2c(c1)C(=O)c1cc([R2])cc(O)c1C2=O</smiles>

260. $\mathrm{R}_{1}=\mathrm{CH}_{3} ; \mathrm{R}_{2}=\mathrm{OCH}_{3}$

261. $\mathrm{R}_{1}=\mathrm{H} ; \mathrm{R}_{2}=\mathrm{CH}_{3}$

262. $\mathrm{R}_{1}=\mathrm{CH}_{3} ; \mathrm{R}_{2}=\mathrm{OH}$

FIGURE 9 | Structures of quinone compounds in $X$. sorbifolium.

n-butanol extracts of $X$. sorbifolium wood $\left(1.5 \mathrm{~g} \mathrm{~kg}^{-1}\right)$ significantly inhibited the swellings in inflamed feet, noninflamed feet, and forelimbs of Wistar male rats induced by the intradermal injection of Freund's complete adjuvant $(0.1 \mathrm{ml})$ in the plantar region of the foot. These results indicated that n-butanol extracts from lignum xanthocerais had an inhibitory effect on primary and secondary joint swelling in rats with adjuvant arthritis and improved the systemic symptoms of adjuvant arthritis in rats (Kuang and Liu, 2002).

At present, most reports only used the crude extract to verify the anti-inflammatory activity of $X$. sorbifolium. Although it has been verified in vivo and in vitro, there are still great shortcomings in the research of $X$. sorbifolium. Therefore, more extensive pharmacological studies should be carried out to clarify the mechanism underlying the anti-inflammatory effect of $X$. sorbifolium and determine its active compounds to provide reliable data to support the development and utilization of $X$. sorbifolium.

\section{Anti-Tumor Activity}

In general, the anti-tumor activities of natural products are often evaluated by their ability to inhibit the proliferation of tumor cells and induce immune cells to secrete cytokines that act on tumor cells (Keawsard et al., 2012). The functional constituents of natural plant resources as anti-cancer agents have become increasingly popular, with many focusing on barrigenol triterpenes.

In one study, xanthoceraside $(10 \mu \mathrm{M})$ significantly inhibited the proliferation of human melanoma A375. S2 cells through the mitochondrial pathway in a concentration- and time-dependent manner without impairing the viability of normal cells and increased the percentage of cells in the sub- $G_{1}$ phase (Jiao 
<smiles>COc1cc(C(=O)O)cc(OC)c1OC</smiles>

263<smiles>O=C(O)CCC(=O)O</smiles>

264<smiles>CC(O)C1CCC(C(=O)O)CC1</smiles>

265

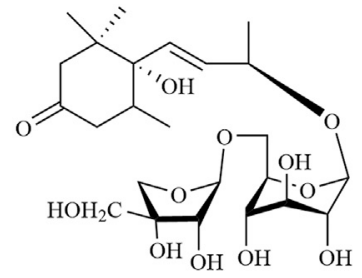

266<smiles>C/C(=C\c1ccccc1/C(C)=C/c1cc(/C=C/c2ccccc2C#N)ccc1/C(C)=C/c1ccccc1C#N)C(=O)O</smiles>

267

268<smiles>CO[C@H]1[C@@H](O)[C@@H](O)[C@H](O)[C@H](O)[C@H]1O</smiles><smiles>CCCCCCCCC(=O)OCC</smiles>

271<smiles>CCCCCCC[C@H](C)C/C=C/C(=O)OC</smiles>

272<smiles>CCCCCCCCCCCCCCCCCO</smiles>

273

270<smiles>CCCCCCCCCCCCCCCCCOC(=O)CCCCCCCCCCCCCC</smiles>

274<smiles>OCCc1ccc(OOc2ccc(CCO)cc2)cc1</smiles><smiles>Cc1c(O)cc2c(c1C)OC(C)(CCCC(C)CCCC(C)CCCC(C)C)CC2</smiles>

275<smiles>O=C1O[C@H]([C@@H](O)CO)C(O)=C1O</smiles>

FIGURE 10 | Structures of other compounds in X. sorbifolium.

et al., 2014). Moreover, Wang et al. (2016b) adopted the CCK-8 method to test the $\mathrm{n}-\mathrm{BuOH}$ layer of a $70 \%$ X. sorbifolium husk extract and 10 barrigenol-like triterpenoids against cancer cells of the human hepatoma cell line (HepG2), human colorectal cancer cell line (HCT-116), and human glioma cell line (U87-MG). The results showed that the $\mathrm{n}-\mathrm{BuOH}$ layer of a $70 \% X$. sorbifolium husk extract exhibited many anti-tumor activities against HepG2, HCT-116, and U87-MG cell lines, with $\mathrm{IC}_{50}$ values of 15.3, 6.7, and $16.3 \mu \mathrm{g} \mathrm{mL}^{-1}$, respectively (Wang et al., 2016b). Furthermore, Chan (2007) isolated xanthoceraside from an $80 \%$ ethanol extract of $X$. sorbifolium husk, and determined its effect on the growth of various human cancer cell lines, including OVCAR3 (ovary), HTB-9 (bladder), U2OS (bone), DU145 (prostate), K562 (leukocyte), HepG2 (liver), MCF-7 (breast), T98G (brain), HCT116 (colon), H460 (lung), SKMel-5 (skin), and HeLa-S3 (cervix) cell lines, using the MTT assay with $\mathrm{IC}_{50}$ values of $14.5 \pm 1,48.3 \pm 3,46.7 \pm 8,41.7 \pm 8$, $44.3 \pm 6,57 \pm 11,65 \pm 0,77.5 \pm 11,103.3 \pm 3,112.5 \pm 4,115 \pm 7$, and $130 \pm 14 \mu \mathrm{g} \mathrm{mL}^{-1}$, respectively.

Xanthoceras sorbifolium has an inhibitory effect on a variety of cancer cells. However, CCK-8 and MTT methods can only verify its inhibitory effect but fail to reveal the exact molecular 
TABLE 1 | The compounds isolated from $X$. sorbifolium.

NO. Compounds classification and name

Plant parts

References

Triterpenoids

\begin{tabular}{|c|c|c|}
\hline 01 & $\mathrm{R}_{1}$-barrigenol & Husks/Carpophores \\
\hline 02 & 21-O-angeloyl- $\mathrm{R}_{1}$-barrigenol & Husks/Carpophores \\
\hline 03 & 22-O-angeloyl- $\mathrm{R}_{1}$-barrigenol & Husks/Carpophores \\
\hline 04 & 21,22-di-O-angeloyl - $R_{1}$-barrigenol & Husks/Carpophores \\
\hline 05 & 21,22-di-O-angeloyl-24-hydroxy- $\mathrm{R}_{1}$-barrigenol & Husks/Carpophores \\
\hline 06 & 28-O- $\beta$-D-glucopyranosyl-21-O-angeloyl- $\mathrm{R}_{1}$-barrigenol & Husks/Carpophores \\
\hline 07 & 21-O-angeloyl-24-hydroxy- $R_{1}$-barrigenol & Husks/Carpophores \\
\hline 08 & xanifolia $Y_{0}$ & Husks \\
\hline 09 & xanifolia $Y_{2}$ & Husks \\
\hline 10 & xanifolia $Y_{3}$ & Husks \\
\hline 11 & xanifolia $Y_{7}$ & Husks \\
\hline 12 & $\begin{array}{l}\text { 3-O-(3-O- } \alpha \text {-L-arabinofuranosyl-2-O- } \beta \text {-D-galactopyranosyl)-(6-O-methyl)- } \beta \text {-D- } \\
\text { glucuronopyranosyl-21,22-di-O-angeloyl- } \mathrm{R}_{1} \text {-barrigenol }\end{array}$ & Husks/Carpophores \\
\hline
\end{tabular}

13 3-O- $\beta$-D-galactopyranosyl-( $1 \rightarrow 6)-(2-O$-angeloyl)- $\beta$-D-glucopyranosyl saniculagenic C- Husks 28-O- $\alpha$-L-rhamnopytanosyl- $(1 \rightarrow 2)-\beta$-D-glucopyranoside

14 3-O-[ $\beta$-D-galactopyranosyl $(1 \rightarrow 2)]-\alpha$-L-arabinofuranosyl $(1 \rightarrow 3)-\beta$-D-methyl glucuronic acid-21, 22-O-diangeloyl-3 $\beta, 15 \alpha, 16 \alpha, 21 \beta, 22 \alpha, 28 \beta$-hexahydroxyl-olean-12-ene

15 3-O-(2-O- $\beta$-D-glucopyranosyl)-(6-O-methyl)- $\beta$-D-glucuronopyranosyl-21,22-di$\mathrm{O}$-angeloy- $\mathrm{R}_{1}$-barrigenol

16 3-O-(2-O- $\beta$-D-glucopyranosyl)-(6-O-methyl)- $\beta$-D-glucuronopyranosyl-21-O-(3', $4^{\prime}$-diO-angeloyl)- $\beta$-D-fucopyranosyl-22-O-acetyl- $\mathrm{R}_{1}$-barrigenol

17 xanthoceraside

$18 \quad 6^{\prime}$-methylether-O-xanifolia- $Y_{5}$

$19 \quad 6^{\prime}$-methylester-O-xanifolia- $Y_{2}$

20 xanifolia $Y$

21 xanifolia $\mathrm{ACH}-\mathrm{Y}$

22 barringtogenol $\mathrm{C}$

23 22-O-angeloyl-21-O-epoxyangeloyl-barringtogenol C

24 22-O-acetyl-21-O-(4'-O-angeloyl)- $\beta$-D-fucopyranosyl theasapogenol B

21,22-di-O-angeloyl-barringtogenol $\mathrm{C}$

xanifolia $Y_{8}$

xanifolia $Y_{10}$

Husks

Leaves

Leaves

Trunks and branches

Husks

Husks

Husks

Husks

Husks

Husks

Carpophores

Husks

Husks

Husks

3- O-[ $\beta$-D-galactopyranosyl $(1 \rightarrow 2)]-\alpha$-L-arabinofuranosyl $(1 \rightarrow 3)-\beta$-D-methyl glucuronic Husks acid-21-O-(3,4-diangeloyl)- $\alpha$-L-rhamnose-3 $\beta, 16 \alpha, 21 \beta, 22 \alpha, 28 \beta$-pentahydroxyl-22acetoxy-olean-12-ene

29 21,22-diangeloyl- $R_{1}$-barrigenol

30 21,22-diangeloyl-24-hydroxy- $\mathrm{R}_{1}$-barrigenol

$313-O-\beta$-D-glucopyranosyl $(1 \rightarrow 6)[\alpha$-L- $\alpha$-rabinofuranosy $(1 \rightarrow 2)]-\beta$-D-glucopyranosyl21,22-di-O-angeloyl- $R_{1}$-barringenol

32 16-deoxybarringtogenol $\mathrm{C}$

33 16-O-acetyl-21-O-(4-O-angeloyl- $\alpha$-L-rhamnopytanosyl)-barringtogenol C

34 3-O- $\beta$-D-glucopyranosyl $(1 \rightarrow 6)-\beta$-D-glucopyranosyl- 28-O- $\beta$-D-glucopyranosyl $(1 \rightarrow 6)$ $[\alpha$-L-rhamnopyranosyl $(1 \rightarrow 2)]-\beta$-D-glucopyranosyl-16-deoxybarringtogenol $\mathrm{C}$

35 sorbifoliaside $A$

36 sorbifoliaside B

37 sorbifoliaside $C$

38 sorbifoliaside D

39 sorbifoliaside E

40 sorbifoliaside F

41 sorbifoliaside $\mathrm{G}$

42 sorbifoliaside $\mathrm{H}$

43 sorbifoliaside I

44 sorbifoliaside

45 3-O-[ $\beta$-D-glucopyranosyl $(1 \rightarrow 6)]\left(3^{\prime}-O\right.$-angeloyl)- $\beta$ - $D$-glucopyranosyl-28-O- $\alpha$ - Lrhamnopytanosyl $(1 \rightarrow 2)]-\beta$-D-glucopyranosyl-16-deoxybarringtogenol $\mathrm{C}$

46 3- O- $\beta$-D-glucopyranosyl $(1 \rightarrow 6)$ - $\beta$-D-glucopyranosyl-28-O- $\beta$-D-glucopyranosyl $(1 \rightarrow 6)$ $[\alpha$-L-rhamnopytanosyl $(1 \rightarrow 2)]$ - $\beta$-D-glucopyranosyl-16-deoxybarringtogenol $\mathrm{C}$

47 3-O- $\beta$ - $D$-glucopyranosyl-16-deoxybarringtogenol $\mathrm{C}$

48 16-O-acetyl-21-O-(4-O-angeloyl- $\alpha$-L-rhamnopyranosyl)-barringtogenol $\mathrm{C}$



$50 \quad 28-O-\beta-D$-glucopyranosyl-16-deoxybarringtogenol C

Husks

Husks

Leaves

Husks/Carpophores Husks/Carpophores

Leaves

Husks/Carpophores Husks/Carpophores Husks/Carpophores Husks/Carpophores Husks/Carpophores Husks/Carpophores Seed oil residue Seed oil residue Seed oil residue Seed oil residue Carpophores

Husks/Carpophores

Husks/Carpophores Husks Husks/Carpophores Husks
Li (2006a)

Lin et al. (2004)

Li (2006a)

Li et al. (2005a)

Li (2006a)

Wang et al. (2011); Li and Li (2014)

Li and Li (2008)

Chan et al. (2008)

Chan et al. (2008)

Chan et al. (2008)

Chan et al. (2008)

Wang et al. (2011)

Wan et al. (2013)

Guo et al. (2009)

Xiao et al. (2013)

Xiao et al. (2013)

Liu et al. (2013)

Wang et al. (2016a)

Wang et al. (2016a)

Wang et al. (2016a)

Wang et al. (2016a)

Li (2006a)

Li (2006a)

Li et al. (2016a); Li et al. (2006c)

Li et al. (2005a)

Chan et al. (2008)

Chan et al. (2008)

Guo et al. (2009)

Li et al. (2005b)

Li et al. (2005b)

Xiao et al. (2013)

Li (2006a)

Li (2006a)

Xiao et al. (2013)

Yu et al. (2012a)

Yu et al. (2012a)

Yu et al. (2012a)

Yu et al. (2012a)

Yu et al. (2012a)

Yu et al. (2012a)

Yu et al. (2012b)

Yu et al. (2012b)

Yu et al. (2012b)

Yu et al. (2012b)

Li et al. (2008)

Li et al. (2016a)

Wang et al. (2011); Li and Li (2014)

Li (2006a)

Li et al. (2007d)

Li (2006a); Li et al. (2007c)

(Continued on following page) 
TABLE 1 | (Continued) The compounds isolated from $X$. sorbifolium.

NO.

Compounds classification and name

$51 \quad 3-O-\beta$ - $D$-glucopyranosyl,28-O-[ $\alpha$-L-rhamnosyl $(1 \rightarrow 2)]-\beta$ - $D$-glucopyranosyl-16deoxybarringtogenol $\mathrm{C}$

$523-O-\beta$-D-glucopyranosyl-28-O-[ $\beta$-D-glucopyranosyl $(1 \rightarrow 2)]-\beta$-D-glucopyranosyl$21 \beta, 22 \alpha$-dihydroxyl-olean-12-ene

53 3-O- $\beta$-D-glucopyranosyl-28-O-[ $\alpha$-L-rhamnopyranosyl $(1 \rightarrow 2)]-\beta$-D-glucopyranosyl$21 \beta, 22 \alpha$-dihydroxyl-olean-12-ene

$543-O-\beta$ - $D$-glucopyranosyl $(1 \rightarrow 6)$-[angeloyl $(1 \rightarrow 2)]-\beta$ - $D$-glucopyranosyl-28-O$\alpha$ - $L$-rhamnopyranosyl $(1 \rightarrow 2)$-[ $\beta$ - $D$-glucopyranosyl $(1 \rightarrow 6)]-\beta$ - $D$-glucopyranosyl$21 \beta, 22 \alpha$-dihydroxylolean-12-ene

553 - O- $\beta$ - $D$-glucopyranosyl $(1 \rightarrow 6)-\left(2^{\prime}\right.$-angeloyl)- $\beta$ - $D$-glucopyranosyl-28-O$\beta$-D-glucopyranosyl $(1 \rightarrow 6)[\alpha$-L-rhamnopytanosyl $(1 \rightarrow 2)]-\beta$-D-glucopyranosyl-16deoxybarringtogenol $\mathrm{C}$

56 3-O- $\beta$-D-glucopyranosyl $(1 \rightarrow 6)-\beta$-D-glucopyranosyl-28-O-[ $\alpha$-L-rhamnosyl $(1 \rightarrow 2)-\beta$-Dglucopyranosyl-16-deoxybarringtogenol $\mathrm{C}$

57 3-O-[ $\beta$-D-glucopyranosyl $(1 \rightarrow 6)-\left(3^{\prime}-O\right.$-angeloyl)- $\beta$-D-glucopyranosyl]-28-O- $\beta$-Dglucopyranosyl $(1 \rightarrow 6)[\alpha$-L-rhamnopyranosyl $(1 \rightarrow 2)-\beta$-D-glucopyranosyl] 16 deoxybarringtogenol $\mathrm{C}$

$58 \quad 28-O-\beta$ - $D$-glucopyranosyl-16-deoxybarringtogenol C

$593-O-[\beta$-D-glucopyranosyl $(1 \rightarrow 6)] 3^{\prime}$ - angeloyl)- $\beta$-D-glucopyranosyl-28-O- $[\alpha-\mathrm{L}$ rhamnosyl $(1 \rightarrow 2)$ ]- $\beta$-D-glucopyranosyl-16-deoxybarringtogenol $\mathrm{C}$

60 xanthohuskisides $A$

61 xanthohuskisides $B$

$62 \quad 21 \beta$-O-acetylxanthohuskiside A

63 3-O- $\beta$-D-glucopyranosyl-28-O-[ $\alpha$-L-rhamnopyranosyl $(1 \rightarrow 2)]-\beta$-D-glucopyranosyl-16deoxybarringtogenol $\mathrm{C}$

643 - O-[ $\beta$-D-glucopyranosyl $(1 \rightarrow 6)]$-[(3-O-angeloyl)- $\beta$-D-glucopyranosyl $(1 \rightarrow 2)]-\beta$-Dglucopyranosyl-28-O-[ $\beta$-D-glucopyranosyl $(1 \rightarrow 6)]$ - $\alpha$-L-rhamanopyranosyl $(1 \rightarrow 2)]-\beta$-Dglucopyranosyl-16-deoxybarringtogenol $\mathrm{C}$

65 3-O-[ $\beta$-D-glucopyranosyl $(1 \rightarrow 6)]$-(3-O-angeloyl) - $\beta$-D-glucopyranosyl-28-O- $\alpha-\mathrm{L}$ rhamanopyranosyl $(1 \rightarrow 2)]-\beta$-D-glucopyranosyl-16-deoxybarringtogenol $\mathrm{C}$

66 sorbifoliaside

$67 \quad$ xanifolia $\mathrm{O}_{54}$

68 3-O- $\beta$-D-glucopyranosyl (1 $\rightarrow 6)-\beta$-D-glucopyranosyl-28-O- $\alpha$-L-rhamnopyranosyl $(1 \rightarrow 2)[\beta$-D-glucopyranosyl $(1 \rightarrow 6)] \beta$-D-glucopyranosyl-21 $\beta, 22 \alpha$-dihydroxyl-olean12,15-diene

69 3-O- $\beta$-D-glucopyranosyl ( $1 \rightarrow 2)-\beta$-D-glucopyranosyl-28-O- $\alpha$-L-rhamnopyranosyl $(1 \rightarrow 2)[\beta$-D-glucopyranosyl $(1 \rightarrow 6)] \beta$-D-glucopyranosyl-21 $\beta, 22 \alpha$-dihydroxyl-olean12-ene

70 3-O-[a-L-arabinofuranosyl $(1 \rightarrow 3)]-[\beta$-D-galactopyranosyl $\rightarrow 2)]-\beta$-D- $(6-O-n-$ butyl)glucuronopyranosyl-21-O-(3,4-O-diangeloyl)- $\beta$-D-fucopyranosyl-22-O-acetylbarringtogenol

$713-O-[\alpha$-L-arabinofuranosyl $(1 \rightarrow 3)]-[\beta$-D-galactopyranosyl $(1 \rightarrow 2)]-\beta$-D-(6-O-n-butyl)glucuronopyranosyl-21-O-(3,4-O-diangeloyl)- $\beta$-D-fucopyranosyl-28-O-acetylbarringtogenol $\mathrm{C}$

72 3-O-[ $\alpha$-L-arabinofuranosyl $(1 \rightarrow 3)]$-[ $\beta$-D-galactopyranosyl $(1 \rightarrow 2)]-\beta$-D-(6-O-n-butyl)glucuronopyranosyl-21,22-O-diangeloyl- $\mathrm{R}_{1}$-barrigenol $\mathrm{C}$

73 3-O-[ $\alpha$-L-arabinofuranosyl $(1 \rightarrow 3)]-[\beta$-D-galactopyranosyl $(1 \rightarrow 2)]-\beta$-D-(6-O-n-butyl)glucuronopyranosyl-21-O-angeloyl-22-O-(2-methyl)butyryl- $\mathrm{R}_{1}$-barrigenol $\mathrm{C}$

74 3-O-[ $\alpha$-L-arabinofuranosyl $(1 \rightarrow 3)]-[\beta$-D-glucopyranosyl $(1 \rightarrow 2)]-\beta$-D-(6-O-n-butyl)glucuronopyranosyl-21,22-O-diangeloyl-24-hydroxy- $\mathrm{R}_{1}$-barrigenol

75 3- O-[ $\alpha$-L-arabinofuranosyl $(1 \rightarrow 3)]-[\beta$-D-galactopyranosyl $(1 \rightarrow 2)]-\beta$-D-(6-O-n-butyl)glucuronopyranosyl-21,22-O-diangeloyl- $\beta$ arringtogenol C

76 napoleogenin $\mathrm{B}$

77 22-O-acnapoleogenin B

$78 \quad 21-0$-(3,4-di-O-angeloyl)- $\beta$-D-fucopyranosyl theasapogenol B

79 21-O-(4-O-acetyl-3-O-angeloyl)- $\beta$-D-fucopyranosyl theasapogenol B

80 21-O-(4-O-acetyl-3-O-angeloyl)- $\beta$-D-fucopyranosyl-22-O-acetyl protoaescigenin

$813-O-[\alpha$-L-arabinofuranosyl $(1 \rightarrow 3)]-\beta$-D-galactopyranosyl $(1 \rightarrow 2)-\beta$-D-6'-n-butylglucuronic acid-21-O-epoxyangeloyl-22-O-angeloyl-3 $\beta, 16 \alpha, 21 \beta, 22 \alpha, 28$ pentahydroxyolean-12-ene

82 16-O-acetyl-aesculioside $\mathrm{G}_{12}$

83 3- O-[ $\alpha$-L-arabinofuranosyl $(1 \rightarrow 3)]-\beta$-D-galactopyranosyl $(1 \rightarrow 2)-\beta$-D-6' - methyl-

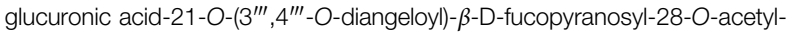
$3 \beta, 16 \alpha, 21 \beta, 22 \alpha, 28$-pentahydroxy-olean-12-ene

Plant parts

References

Carpophores

Husks

Husks

Husks/Carpophores

Leaves

Leaves

Leaves

Husks

Carpophores

Husks

Husks

Husks

Husks

Husks

Husks

Husks

Husks

Husks

Husks

Husks

Husks

Husks

Husks

Husks

Husks

Husks/Carpophores

Husks/Carpophores

Husks/Carpophores

Husks/Carpophores

Husks/Carpophores

Husks

Husks

Husks
Li et al. (2008)

Cui et al. (2012)

Cui et al. (2012)

Cui et al. (2012)

Xiao et al. (2013)

Xiao et al. (2013)

Xiao et al. (2013)

Li (2006a)

Li et al. (2008)

Li et al. (2013d)

Li et al. (2013d)

Wang et al. (2018)

Wang et al. (2016b)

Wang et al. (2016b)

Wang et al. (2016b)

Fu et al. (2010)

Fu et al. (2010)

Li et al. (2013c)

Li et al. (2013c)

Wang et al. (2016b)

Wang et al. (2016b)

Wang et al. (2016b)

Wang et al. (2016b)

Wang et al. (2016b)

Wang et al. (2016b)

Chen et al. (1985b)

Chen et al. (1985b)

Chen et al. (1985a)

Chen et al. (1985a)

Chen et al. (1985a)

Wang et al. (2016a)

Wang et al. (2016a) Wang et al. (2016a) 
TABLE 1 | (Continued) The compounds isolated from $X$. sorbifolium.

NO.

Compounds classification and name

$84 \quad 6^{\prime}$-methylester-O-xanifolia- $Y_{8}$

85 bunkankasaponin $\mathrm{A}$

86 bunkankasaponin $\mathrm{B}$

87 bunkankasaponin C

88 bunkankasaponin D

89 bunkankasaponin $\mathrm{F}$

$90 \quad 3-O-\beta$-D-glucuronopyranoside bunkanka saponin A

91 16-O-acetyl-21-O-(3,4-di-O-angeloyl)- $\beta$-D-fucopyranosyl protoaescigen

92 oleanolic acid

$93 \quad \beta$-arabinopyranosyl-( $1 \rightarrow 4)$-[O- $\beta$-D-galactopyranosyl-( $1 \rightarrow 6)-O-\beta$-D-glucopyranosyl-

$(1 \rightarrow 3)]-O-\beta$-D-glucopyranosyluronic acid- $(1 \rightarrow 3)$-gypsogenin

94 3-O-[ $\beta$-D-galactopyranosyl $(1 \rightarrow 2)-\alpha$-L-arabinofuranosyl- $(1 \rightarrow 3)-\beta$-D-methyl glucuronic acid 21-O-(3,4-diangeloyl)- $\alpha$-L-rhamnose-3 $\beta, 16 \alpha, 21 \beta, 22 \alpha, 28 \beta$-pentahydroxyl-22acetoxy-olean-12-ene

95 sorbifoliasides $\mathrm{K}$

96 3ß,23-dihydroxy-lup-20 (29)-en-28-oic acid-23-caffeate

$973 \beta, 23$-dihydroxy-lup-20 (29)-en-28-oic acid-3-caffeate

98 betulin

99 23-hydroxybetulinic acid

$1003 \alpha, 29$-dihydroxytirucalla-7, 24-dien-21-oic acid

$1013 \beta$-hydroxytirucalla-7, 24-dien-21-oic acid

102 29-hydroxy-3-oxotirucalla-7,24-dien-21-oic acid

103 29-O-acetyl-3-oxotirucalla-7,24-dien-21-oic acid

104 33,29-dihydroxytirucalla-7, 24-dien-21-oic acid

105 3-oxotriucalla-7, 24-dien-21-oic acid

106 24-methylenecycloartan-3-ol

107 protoaescigenin

108 3-O-[ $\alpha$-L-arabinofuranosyl $(1 \rightarrow 3)]$-[ $\beta$-D-galactopyranosyl $(1 \rightarrow 2)]-\beta$-D-6O-methylglucuronopyranosyl-21-O-angeloyl-22-O-(2-methyl) butyryl-R1-barrigeno

109 3-O- $\alpha$-D-glucopyranosyl-21,22-di-O-angeloyl-R1-barrigenol

110 3-O- $\beta$-D-6-O-methyl-glucuronopyranosyl-21-O-angeloy-22-O-isobutyryl-R1barrigenol

111 21-acetyl-3-O-[ $\beta$-D-glucopyranosyl $(1 \rightarrow 6)]$ - [angeloyl $(1 \rightarrow 3)]-\beta$-D-glucopyranosyl-28O-[ $\alpha$-L-rhamnopyranosyl $(1 \rightarrow 2)]$ - $\beta$-D-glucopyranosyl-16-deoxy-barringtogenol $\mathrm{C}$

112 21-O-acetyl-3-O- [ $\beta$-D-glucopyranosyl $(1 \rightarrow 6)]$-[angeloyl $(1 \rightarrow 3)]-\beta$-D-4-O-acetylglucopyranosyl-28-O-[ $\alpha$-L-rhamnopyranosyl $(1 \rightarrow 2)]-\beta$-D-glucopyranosyl-16deoxybarringtogenol $\mathrm{C}$

113 21-acetyl-3-O-[ $\beta$-D-glucopyranosyl $(1 \rightarrow 6)]$-[angeloyl $(1 \rightarrow 4)]-\beta$-D-glucopyranosyl-28O-[ $\alpha$-L-rhamnopyranosyl $(1 \rightarrow 2)]-\beta$-D-glucopyranosyl-16-deoxy-barringtogenol C

114 28-O-acetyl-21-O- $\beta$-D-fucopyranosyl barrigenol C

115 21-O-(3,4-di-O-angeloyl)- $\beta$-D-fucopyranosyl-R1-barrigenol

$1163-O-\alpha$-D-glucuronopyranosyl-21,22-di-O-angeloyl-R1-barrigenol

117 21-O-epoxyangeloyl-22-O-angeloyl-R1-barrigenol

118 21-O-(2, 3-di- hydroxy-2-methylbutyryl)-22-O-angeloyl-R1-barrigenol

119 28-O-isobutyryl-21-O-angeloyl-R1-barrigenol

120 3-O- $\beta$-D-6-O-methylglucuronopyranosyl-21-O-angeloyl-R1-barrigenol

$1213-O-\beta$-D-6-O-methylglucuronopyranosyl-21-O-angeloyl-22-O-isobutyryl-R1barrigenol

122 3-O- $\beta$-D-6-O-methylglucuronopyranosyl-21,22-di-O-angeloyl-R1-barrigenol

123 3-O- $\beta$-D-6-O-methylglucuronopyranosyl- 21-O-(3,4-di-O-angeloyl- $\beta$-D-fucopyranosyl) barrigenol $\mathrm{C}$

1243 3-O-[ $\beta$-D-glucopyranosyl $(1 \rightarrow 6)]$-(2-angeloyl)- $\beta$-D-glucopyranosyl-28-O- $\beta$-Dglucopyranosyl $(1 \rightarrow 6)[\alpha$-L-rhamnopyranosyl $(1 \rightarrow 2)$ - $\beta$-D-glucopyranosyl]-21-O-acetyl16-deoxybarringtogenol $\mathrm{C}$

125 quercetin
126 myricetin
127 kaempferol

Flavonoids

\begin{tabular}{ll}
\hline Flavonoids & Fon
\end{tabular}

Plant parts

\section{References}

Husks

Seed oil residue

Seed oil residue

Seed oil residue

Seed oil residue

Seed oil residue

Husks/Carpophores

Husks/Carpophores

Husks/Carpophores/Trunks and

branches

Husks/Carpophores

Husks

Seed oil residue

Husks/Carpophores

Husks/Carpophores

Husks/Carpophore/Flowers

Husks/Carpophores

Husks/Carpophores

Trunks and branches

Trunks and branches

Trunks and branches

Trunks and branches

Trunks and branches

Trunks and branches

Husks/Carpophores

Husks

Husks

Husks

Husks

Husks

Husks

Husks

Husks

Husks

Husks

Husks

Husks

Husks

Husks

Husks

Husks

Husks
Wang et al. (2016a)

Yu et al. (2012a)

Yu et al. (2012a)

Yu et al. (2012a)

Yu et al. (2012a)

Yu et al. (2012a)

Chen et al. (1985c)

Chen et al. (1985c)

Ma et al. (2000)

Chirva and Kintya (1971)

Guo et al. (2009)

Yu et al. (2012b)

Li et al. (2007d)

$\mathrm{Li}$ and Li (2008a)

Li et al. (2005a); Zhao et al. (2012)

Li and Li (2008a)

Ma et al. (2000)

Ma et al. (2000)

Ma et al. (2000)

Ma et al. (2000)

Ma et al. (2000)

Ma et al. (2000)

Ma et al. (2000)

Chen et al. (1985b)

Chen et al. (2020a)

Chen et al. (2020a)

Chen et al. (2020a)

Chen et al. (2020a)

Chen et al. (2020a)

Chen et al. (2020a)

Chen et al. (2020a)

Chen et al. (2020a)

Chen et al. (2020a)

Chen et al. (2020b)

Chen et al. (2020b)

Chen et al. (2020b)

Chen et al. (2020b)

Chen et al. (2020b)

Chen et al. (2020b)

Chen et al. (2020b)

Ding et al. (2019)
Trunks and branches/Leaves/ Husks/Flowers

Trunks and branches/Leaves/

Husks

Trunks and branches/Leaves/ Husks/Flowers
Zhang and Bao (2000); Wu (2017); Zhao et al. (2012)

Zhang and Bao (2000); Wu (2017)

Li (2006a); Zhao et al. (2012)

(Continued on following page) 
TABLE 1 | (Continued) The compounds isolated from $X$. sorbifolium.

\begin{tabular}{|c|c|c|c|}
\hline NO. & Compounds classification and name & Plant parts & References \\
\hline 128 & rhamnocitrin & $\begin{array}{l}\text { Trunks and branches/Leaves/ } \\
\text { Husks/Flowers }\end{array}$ & Zhao et al. (2012) \\
\hline 129 & mearnsetin & Husks & Manthey and Guthrie (2002) \\
\hline 130 & quercimetrin & Husks & Panyadee et al. (2015) \\
\hline 131 & quercitrin & Flowers & Zhao et al. (2012) \\
\hline 132 & isoquercitrin & $\begin{array}{l}\text { Trunks and branches/Leaves/ } \\
\text { Husks }\end{array}$ & $\begin{array}{l}\text { Zhao et al. (2013); Aderogba et al. } \\
\text { (2013) }\end{array}$ \\
\hline 133 & 3-O-methyl-quercetin & $\begin{array}{l}\text { Trunks and branches/Leaves/ } \\
\text { Husks }\end{array}$ & Zhao et al. (2013) \\
\hline 134 & myricitrin & $\begin{array}{l}\text { Trunks and branches/Leaves/ } \\
\text { Husks }\end{array}$ & Kang et al. (2012); Wu (2017) \\
\hline 135 & isomericitrin & Husks/Flowers & Yang et al. (2016a); Zhao et al. (2012) \\
\hline 136 & kaempferol-3-O- $\alpha$-L-rhamnopyranoside & $\begin{array}{l}\text { Trunks and branches/Leaves/ } \\
\text { Husks }\end{array}$ & Zhao et al. (2013) \\
\hline 137 & kaempferol-3-O- $\beta$-D-glucopyranoside & $\begin{array}{l}\text { Trunks and branches/Leaves/ } \\
\text { Husks/Flowers }\end{array}$ & Zhao et al. (2013) \\
\hline 138 & kaempferol-3-O-(2-O- $\alpha$-L-rhamnopyranosyl)-glucopyranoside & $\begin{array}{l}\text { Trunks and branches/Leaves/ } \\
\text { Husks }\end{array}$ & Zhao et al. (2012) \\
\hline 139 & kaempferol-3-O-rutinoside & $\begin{array}{l}\text { Trunks and branches/Leaves/ } \\
\text { Husks/Flowers }\end{array}$ & $\begin{array}{l}\text { Li (2006a); Zhao et al. (2012); Yang } \\
\text { et al. (2016a) }\end{array}$ \\
\hline 140 & rutin & Husks & $\mathrm{Li}(2006 \mathrm{a})$ \\
\hline 141 & chrysoeriol & $\begin{array}{l}\text { Trunks and branches/Leaves/ } \\
\text { Husks/Flowers }\end{array}$ & Zhao et al. (2012) \\
\hline 142 & tricetin & Husks & Yang et al. (2016a) \\
\hline 143 & myricetin 3-O-rutinoside & Husks & Yang et al. (2016a) \\
\hline 144 & isorhamnetin 3-O-rutinoside & Husks & Yang et al. (2016a) \\
\hline 145 & luteolin & Husks & Wan et al. (2015) \\
\hline 146 & naringenin & $\begin{array}{l}\text { Trunks and branches/Leaves/ } \\
\text { Husks/Flowers }\end{array}$ & $\begin{array}{l}\text { Wu (2017); Zhao et al. (2012); Yang } \\
\text { et al. (2016a) }\end{array}$ \\
\hline 147 & eriodictyol & $\begin{array}{l}\text { Trunks and branches/Leaves/ } \\
\text { Husks }\end{array}$ & $\begin{array}{l}\text { Li (2006a); Li et al. (2006b); Yang et al. } \\
\text { (2016a) }\end{array}$ \\
\hline 148 & eriodictyol 4'-O- $\beta$-D-glucopyranoside & Husks & Yang et al. (2016a) \\
\hline 149 & (2S)-eriodictyol-7-O- $\beta$-D-glucopyranoside & Husks & Yang et al. (2016a) \\
\hline 150 & (2R)-eriodictyol-7-O- $\beta$-D-glucopyranoside & Husks & Yang et al. (2016a) \\
\hline 151 & naringenin $5-O-\beta$-D-glucopyranoside & Husks & Yang et al. (2016a) \\
\hline 152 & naringenin $4^{\prime}-O-\beta$-D-glucopyranoside & Husks & Yang et al. (2016a) \\
\hline 153 & (-)-salipurposide & Husks & Yang et al. (2016a) \\
\hline 154 & naringenin-7-O- $\beta$-D-glucopyranoside & Husks & Wan et al. (2015) \\
\hline 155 & $2 \alpha-3^{\prime}, 4^{\prime}, 5,5^{\prime}, 7-$ pentahydroxyflavone & Trunks and branches & Wu (2017) \\
\hline 156 & $3,3^{\prime}, 4^{\prime}, 5,7$-pentahydroxyflavanone & Trunks and branches & Wu (2017) \\
\hline 157 & $2 \beta, 3 \beta-3,3^{\prime}, 5,5^{\prime}$-pentahydroxyflavone & Trunks and branches & Wu (2017) \\
\hline 158 & $2 \alpha, 3 \beta$-dihydroquercetin & $\begin{array}{l}\text { Trunks and branches/Leaves/ } \\
\text { Fruits }\end{array}$ & Zhang and Bao (2000); Wu (2017) \\
\hline 159 & dihydromyricetin & $\begin{array}{l}\text { Trunks and branches/Leaves/ } \\
\text { Husks }\end{array}$ & Zhang and Bao, 2000; Wu (2017) \\
\hline 160 & aromadendrin & Husks & Yang et al. (2016a) \\
\hline 161 & taxifolin & Husks & Yang et al. (2016a) \\
\hline 162 & catechin & Husks & Yang et al. (2016a) \\
\hline 163 & gallocatechin & Trunks and branches/Husks & $\begin{array}{l}\text { Ni and Zhang (2009); Yang et al. } \\
\text { (2016a) }\end{array}$ \\
\hline 164 & (-)-epicatechin & $\begin{array}{l}\text { Trunks and branches/Leaves/ } \\
\text { Husks }\end{array}$ & Zhang and Bao (2000) \\
\hline 165 & (-)-epigallocatechin & $\begin{array}{l}\text { Trunks and branches/Leaves/ } \\
\text { Husks }\end{array}$ & Huang and Feng (1987) \\
\hline 166 & (-)-epiafzelechin & $\begin{array}{l}\text { Trunks and branches/Leaves/ } \\
\text { Husks }\end{array}$ & Ma and Nakamura (2004) \\
\hline 167 & epicatechin-5-O- $\beta$-D-glucopyranaoside & Seed oil residue & Yu et al. (2018) \\
\hline 168 & epigallocatechin-( $4 \beta \rightarrow 8,2 \beta \rightarrow 0-7)$-epicatechin & Trunks and branches & Wu (2017) \\
\hline 169 & procyanidin A-2 & Trunks and branches & Wu (2017) \\
\hline 170 & proanthocyanidin A2 & Trunks and branches & Wu (2017) \\
\hline 171 & cirmamtanninB-1 & Husks & Yang et al. (2016a) \\
\hline 172 & 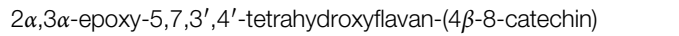 & Trunks and branches & Wu (2017) \\
\hline
\end{tabular}

(Continued on following page) 
TABLE 1 | (Continued) The compounds isolated from X. sorbifolium.

NO. Compounds classification and name

Plant parts

References

Phenylpropanoids

$\begin{array}{ll}173 & \text { fraxin } \\ 174 & \text { fraxetin } \\ 175 & \text { isofraxetin } \\ 176 & \text { isofraxetin-6-O- } \beta \text {-D-glucopyranoside } \\ 177 & \text { fraxetin-7-O- } \beta \text {-D-[6'-(3'-hydroxyl-3'"'- methylglutaryl)] glucopyranoside } \\ 178 & \text { scopoletin } \\ 179 & \text { isoscopoletin } \\ 180 & \text { esculetin } \\ 181 & \text { xanthotoxin } \\ 182 & \text { cleomiscosin D } \\ 183 & \text { cleomiscosin B } \\ 184 & \text { meso-2,3-di }\left(3^{\prime}, 4^{\prime}-\text { methylenedioxybenzyl) butane-1,4-diol }\right. \\ 185 & \text { umbelliferone } \\ 186 & \text { biscopoletin }\end{array}$

$\begin{array}{ll}\text { Seed oil leavings } & \text { Zhu et al. (2018) } \\ \text { Seed oil residue } & \text { Chen et al. (1984) } \\ \text { Fruits } & \text { Li (2006a) } \\ \text { Husks } & \text { Li (2006a) } \\ \text { Seed oil residue } & \text { Zhu et al. (2018) } \\ \text { Seed oil residue } & \text { Zhu et al. (2018) } \\ \text { Flowers } & \text { Zhao et al. (2013) } \\ \text { Seed oil residue } & \text { Zhu et al. (2018) } \\ \text { Husks } & \text { Wan et al. (2015) } \\ \text { Husks } & \text { Li (2006a); Li et al. (2006b) } \\ \text { Husks } & \text { Li et al. (2007b) } \\ \text { Seed oil residue } & \text { Yu et al. (2018) } \\ \text { Husks } & \text { Yang et al. (2020a) } \\ \text { Husks } & \text { Yang et al. (2020a) }\end{array}$

Steroids



$\begin{array}{ll}\text { Husks/Carpophores } & \text { Wan et al. (2013) } \\ \text { Husks } & \text { Li et al. (2007a) } \\ \text { Husks } & \text { Cheng et al. (200 }) \text { Cheng et al. (200 } \\ \text { Husks } & \text { Li et al. (2005a) } \\ \text { Husks } & \text { Li (2006a) } \\ \text { Husks } & \text { Li (2006a) } \\ \text { Husks } & \text { Li (2006a) } \\ \text { Husks } & \text { Li et al. (2005a) } \\ \text { Carpophores } & \text { Li et al. (2005a) } \\ \text { Carpophores } & \text { Li et al. (2005a) } \\ \text { Carpophores } & \text { Li et al. (2005a); Y } \\ \text { Trunks and branches/seed oil } & \\ \text { residue } & \text { Dong et al. (2008); } \\ \text { Trunks and branches/seed oil } & \\ \text { residue } & \text { Yan et al. (1984) } \\ \text { Kernel oil } & \text { Yan et al. (1984) } \\ \text { Kernel oil } & \text { Yan et al. (1984) } \\ \text { Kernel oil } & \text { Yan et al. (1984) } \\ \text { Kernel oil } & \end{array}$

\begin{tabular}{|c|c|c|c|}
\hline \multicolumn{4}{|c|}{ Phenols } \\
\hline 204 & 2-hydroxy-6-methylbenzoic acid & Trunks and branches/Husks & Li (2006a); Wu (2017) \\
\hline 205 & vanillic acid & Husks & Li (2006a) \\
\hline 206 & gallic acid & Husks & Yang et al. (2016a) \\
\hline 207 & tyrosol & Husks & Li (2006a) \\
\hline 208 & 4-hydroxyphenylacetic acid & Husks & Li (2006a) \\
\hline 209 & protocatechuic acid & Husks & Yang et al. (2016a) \\
\hline 210 & isochlorogenic acid B & Trunks and branches & Wu (2017) \\
\hline 211 & 4-hydroxybenzaldehyde & Husks & Li (2006a) \\
\hline 212 & p-hydroxybenzoic acid & Husks & Yang et al. (2016a) \\
\hline 213 & xspolyphenol A & Husks & Yang et al. (2016a) \\
\hline 214 & xspolyphenol B & Husks & Yang et al. (2016a) \\
\hline 215 & pyrogallol & Husks & Yang et al. (2016a) \\
\hline 216 & hydroquinone & Husks & Wan et al. (2015) \\
\hline 217 & 4-hydroxybenzylcyanide & Husks & Wan et al. (2015) \\
\hline 218 & 5,7-dihydroxychromone & $\begin{array}{l}\text { Trunks and branches/Leave/ } \\
\text { Husk }\end{array}$ & Li (2006a) \\
\hline 219 & methyl 4-hydroxylbenzoate & Husks & Yang et al. (2016a) \\
\hline 220 & methyl caffeoate & Seed oil residue & Yu et al. (2018) \\
\hline
\end{tabular}

Fatty acids

221 nonadecanoic acid

222 heneiosanoic acid

223 tetracosanoic acid
Trunks and branches

Trunks and branches

Trunks and branches
Li et al. (2007a)

Li et al. (2007a)

Li et al. (2007a)

(Continued on following page) 
TABLE 1 | (Continued) The compounds isolated from X. sorbifolium.

No.

Compounds classification and name

224 myristic acid

225 palmitoleic acid

226 arachidic acid

227 docosadienoic acid

228 tricosanoic acid

229 nervonic acid

230 oleic acid

231 erucic acid

232 linolenic acid

233 eicosadienoic acid

234 stearic acid

235 eicosanoic acid

236 lignoceric acid

237 behenic acid

238 dodecanoic acid

239 hexanoic acid

240 heptanoic acid

241 nonanoic acid

242 decanoic acid

243 10-methylundecanoic acid

244 12-methyltetradecanoic acid

245 heptadecanoic acid

246 palmitic acid

247 9,12-octadecadienoic acid

248 9-octadecadienoic acid

249 11-eicosenoic acid
Plant parts

References

Liang et al. (2021)

Liang et al. (2021)

Liang et al. (2021)

Liang et al. (2021)

Liang et al. (2021)

Liang et al. (2021)

Wang (1998)

Wang (1998)

Wang (1998)

Wang (1998)

Wang (1998)

Wang (1998)

Wang (1998)

Wang (1998)

Wang (1998)

Cheng et al. (2002)

Cheng et al. (2002)

Cheng et al. (2002)

Cheng et al. (2002)

Cheng et al. (2002)

Cheng et al. (2002)

Cheng et al. (2002)

Bao et al. (2012)

Li et al. (2013a)

Li et al. (2013a)

Li et al. (2013a)

Alkaloids

$\begin{array}{ll}250 & \text { 2-methyl-6-(2', 3', 4'-trihydroxybutyl) -pyrazine } \\ 251 & \text { indole-3-carboxaldehyde } \\ 252 & \text { allantoin } \\ 253 & \text { indole-3-acetylaspartic acid } \\ 254 & \text { 1-oxa-2-azaspiro [4.5]dec-2-ene-8-ol } \\ 255 & \text { trans-xanthoisoxazoline A } \\ 256 & \text { cis-xanthoisoxazoline A } \\ 257 & \text { xanthoisoxazoline B } \\ 258 & \text { xanthoisoxazoline C }\end{array}$

\begin{tabular}{ll}
\hline Quinones & Q
\end{tabular}

$\begin{array}{ll}259 & 2,5-\text { dimethoxy-p-benzoquinone } \\ 260 & \text { physcion } \\ 261 & \text { chrysophanol } \\ 262 & \text { emodin }\end{array}$

uinones

\begin{tabular}{|c|c|c|c|}
\hline \multicolumn{4}{|c|}{ Others } \\
\hline 263 & 3,4,5-trimethoxy benzoic acid & Trunks and branches & Li (2006a) \\
\hline 264 & succinic acid & Husks & Chen et al. (1984) \\
\hline 265 & 4-( $\alpha$-hydroxyethyl)cyclohexan-1-oic acid & Husks & Yang et al. (2020a) \\
\hline 266 & vomifoliol-3'-O- $\beta$-D-apiofuranosyl-(1-6)- $\beta$-D-glucopyranoside & Seed oil residue & Yu et al. (2018) \\
\hline 267 & dihydrophaseic acid 3'-O- $\beta$-D-glucopyranoside & Seed oil residue & Yu et al. (2018) \\
\hline 268 & xanthocerapene & Trunks and branches & Wu (2017) \\
\hline 269 & 1,4-di-(2-cyanostyryl)benzene & Husks & Li (2006a) \\
\hline 270 & 1-O-methyl-myo-inositol & Flowers & Zhao et al. (2012) \\
\hline 271 & ethyl nonanoate & Husks & Yang et al. (2020a) \\
\hline 272 & methyl (2E,5S)-(-)-5-methyldodec-2-enoate & Husks & Li (2006a) \\
\hline 273 & heptadecan-1-ol & Husks & Yang et al. (2020a) \\
\hline 274 & pentadecanoic acid heptadecyl ester & Husks & Yang et al. (2020a) \\
\hline 275 & bungeinA & Husks & Yang et al. (2020a) \\
\hline 276 & tocopherols & Kernels & Liang et al. (2021) \\
\hline 277 & vitamin $\mathrm{A}$ & Kernels & Liang et al. (2021) \\
\hline 278 & vitamin C & Kernels & Liang et al. (2021) \\
\hline
\end{tabular}


TABLE 2 | The pharmaceutical effects of $X$. sorbifolium.

\begin{tabular}{|c|c|c|c|c|c|c|}
\hline $\begin{array}{l}\text { Pharmaceutical } \\
\text { effects }\end{array}$ & $\begin{array}{l}\text { Used } \\
\text { part }\end{array}$ & Compounds/extracts & Doses & Models & Results/mechanism & References \\
\hline \multirow[t]{11}{*}{$\begin{array}{l}\text { Improving learning } \\
\text { and memory } \\
\text { impairments }\end{array}$} & $\begin{array}{l}\text { Fruit } \\
\text { stalks }\end{array}$ & 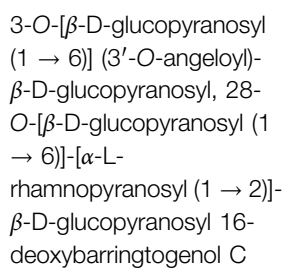 & $0.32 \mathrm{mg} \mathrm{kg}^{-1}$ & $\begin{array}{l}\text { Male } \\
\text { Kunming } \\
\text { (KM) mice }\end{array}$ & $\begin{array}{l}\text { Significantly protective against ICV-A } \beta_{1-42} \text {. } \\
\text { induced learning and memory impairment }\end{array}$ & $\begin{array}{l}\text { Li et al. } \\
(2020)\end{array}$ \\
\hline & Husks & Xanthoceraside & $\begin{array}{l}0.02,0.08 \text { and } \\
0.32 \mathrm{mg} \mathrm{kg}^{-1}\end{array}$ & $\begin{array}{l}\text { Male ICR } \\
\text { mice }\end{array}$ & $\begin{array}{l}\text { Xanthoceraside inhibition of the TLR2 pathway } \\
\text { and down-regulation of MAPK and NF- } \mathrm{B} B \\
\text { activities may be related to the improvement in } \\
\text { learning and memory impairments }\end{array}$ & $\begin{array}{l}\text { Qi et al. } \\
\text { (2017) }\end{array}$ \\
\hline & Husks & Xanthoceraside & $\begin{array}{l}0.056,0.112, \text { and } \\
0.224 \mathrm{mg} \mathrm{kg}^{-1}\end{array}$ & $\begin{array}{l}\text { Male } \\
\text { Sprague- } \\
\text { Dawley (SD) } \\
\text { rats }\end{array}$ & $\begin{array}{l}\text { Xanthoceraside can modulate the structure of gut } \\
\text { microbiota in AD rats, and the gut microbiota may } \\
\text { be potential targeting territory of xanthoceraside } \\
\text { via microbiome-gut-brain pathway }\end{array}$ & $\begin{array}{l}\text { Zhou et al. } \\
\text { (2019) }\end{array}$ \\
\hline & Husks & Xanthoceraside & $\begin{array}{l}0.01,0.05 \text { and } \\
0.1 \mathrm{mg} \mathrm{mL}^{-1}\end{array}$ & $\mathrm{SD}$ rats & $\begin{array}{l}\text { Exhibited obvious neuroprotection against } \\
\text { amyloid- } \beta \text {-induced cytotoxicity on PC12 cells, } \\
\text { indicating their potential to be bioactive } \\
\text { substances against Alzheimer's disease }\end{array}$ & $\begin{array}{l}\text { Rong et al. } \\
\text { (2018) }\end{array}$ \\
\hline & Husks & Xanthoceraside & $\begin{array}{l}0.06,0.12, \text { and } \\
0.24 \mathrm{mg} \mathrm{kg}^{-1}\end{array}$ & Rats & $\begin{array}{l}\text { Both memory deficits and insulin receptor and } \\
\text { insulin-like growth factor-I receptor (IGF-1R) } \\
\text { protein expression levels were ameliorated }\end{array}$ & $\begin{array}{l}\text { Liu et al. } \\
\text { (2013) }\end{array}$ \\
\hline & Husks & Xanthoceraside & 0.01 and $0.1 \mu \mathrm{M}$ & $\begin{array}{l}\text { SH-SY5Y } \\
\text { cells }\end{array}$ & $\begin{array}{l}\text { Significantly increased the survival rate of } \mathrm{SH} \text { - } \\
\text { SY5Y cells injured by } \mathrm{A} \beta_{25-35} \text { in a dose- } \\
\text { dependent manner }\end{array}$ & $\begin{array}{l}\text { Chi et al. } \\
(2013)\end{array}$ \\
\hline & Husks & Total triterpenoid saponins & $\begin{array}{l}0.93,2.8, \text { and } \\
8.4 \mathrm{mg} \mathrm{kg}^{-1}\end{array}$ & $\begin{array}{l}\mathrm{KM} \text { mice and } \\
\mathrm{SD} \text { rats }\end{array}$ & $\begin{array}{l}\text { Significantly improve the impairments of learning } \\
\text { and memory. The preliminary mechanism might } \\
\text { associate with its protection effects against } \\
\text { oxidative stress damage, cholinergic system } \\
\text { deficiency and synaptic damage }\end{array}$ & Ji et al. (2017) \\
\hline & Husks & Crude extract of the husks & $50 \mathrm{mg} \mathrm{kg}^{-1}$ & $\mathrm{SD}$ rat & $\begin{array}{l}\text { Crude extract of the husks from Xanthoceras } \\
\text { sorbifolia might ameliorate the impairment of learning } \\
\text { and memory in the Alzheimer's disease animal } \\
\text { model with similar function of AchEl as huperzine }\end{array}$ & $\begin{array}{l}\text { Sun et al. } \\
(2018)\end{array}$ \\
\hline & Husks & Ethanol extracts & $89.80,44.90 \mathrm{mg} \mathrm{kg}^{-1}$ & KM mice & $\begin{array}{l}\text { It significantly improved the impairment of } \\
\text { learning and memory, and the mechanism may } \\
\text { be related to the enhancement of the function of } \\
\text { the central cholinergic and glutamatergic nervous } \\
\text { systems, and resistance to oxygen consumption } \\
\text { injury in brain tissue }\end{array}$ & $\begin{array}{l}\text { Liu et al. } \\
\text { (2007b) }\end{array}$ \\
\hline & Husks & Ethanol extracts & $\begin{array}{l}\text { 2.5, 5.0, and } \\
10.0 \mathrm{mg} \mathrm{kg}^{-1} \cdot \mathrm{D}^{-1}\end{array}$ & AD rat model & $\begin{array}{l}\text { Oral treatment with XSE significantly reduced } \\
\text { cognitive impairments in behavioral tests (passive } \\
\text { avoidance test, novel object recognition test, } \\
\text { Y-maze test and Morris water maze test). The } \\
\text { cognition-improving effects of XSE probably } \\
\text { resulted from dendritic spine protection effects } \\
\text { through regulation of BDNF signaling pathways. }\end{array}$ & $\begin{array}{l}\text { Li et al. } \\
\text { (2016b) }\end{array}$ \\
\hline & Husks & Ethanol extract & $62.9 \mathrm{mg} \cdot \mathrm{kg}^{-1}$ & Wistar rats & $\begin{array}{l}\text { Significantly improve the learning and memory } \\
\text { ability of rats, increase superoxide dismutase } \\
\text { activity, reduce MDA and acetylcholinesterase } \\
\text { levels, and significantly inhibit the degeneration } \\
\text { and shedding of hippocampal neurons }\end{array}$ & $\begin{array}{l}\text { Liu et al. } \\
\text { (2007a) }\end{array}$ \\
\hline \multirow[t]{2}{*}{ Anti-inflammatory } & Leaves & $\begin{array}{l}\text { Quercetin-3-O- } \beta \text {-D- } \\
\text { glucopyarnoside, } \\
\text { catechin, syringaresinol-4- } \\
\text { O- } \beta \text {-D-glucopyranoside, } \\
4-O-\beta \text {-D-glucopyranosyl- } \\
\text { trans- } p \text {-coumaric acid }\end{array}$ & $\begin{array}{l}\mathrm{IC}_{50} 13.39 \pm 1.27 \mu \mathrm{M} \\
9.52 \pm 2.18 \mu \mathrm{M}, 3.08 \pm \\
1.77 \mu \mathrm{M} \text {, and } 9.08 \pm \\
1.23 \mu \mathrm{M}\end{array}$ & $\begin{array}{l}\text { LPS- } \\
\text { induced BV2 } \\
\text { cells }\end{array}$ & $\begin{array}{l}\text { The compounds exhibited much stronger } \\
\text { inhibiting effect on NO production than that of the } \\
\text { positive control minocycline }\left(\mathrm{IC}_{50} 37.04 \pm\right. \\
2.09 \mu \mathrm{M}) \text { in LPS-induced BV2 cells }\end{array}$ & $\begin{array}{l}\text { Li et al. } \\
\text { (2016a) }\end{array}$ \\
\hline & Husks & Xanthoceraside & 0.01 and $0.1 \mu \mathrm{M}$ & $\begin{array}{l}\text { Microglial } \\
\text { cells }\end{array}$ & $\begin{array}{l}\text { The inhibitory effect of xanthoceraside on pro- } \\
\text { inflammatory mediators was possibly mediated } \\
\text { through TLR2 receptor/MyD88 in } A \beta_{25-35} / \mathrm{IFN} \text {-g- } \\
\text { stimulated N9 microglial cells }\end{array}$ & $\begin{array}{l}\text { Qi et al. } \\
\text { (2013) }\end{array}$ \\
\hline
\end{tabular}


TABLE 2 | (Continued) The pharmaceutical effects of $X$. sorbifolium.

\begin{tabular}{|c|c|c|c|c|c|c|}
\hline $\begin{array}{l}\text { Pharmaceutical } \\
\text { effects }\end{array}$ & $\begin{array}{l}\text { Used } \\
\text { part }\end{array}$ & Compounds/extracts & Doses & Models & Results/mechanism & References \\
\hline & Wood & n-Butanol extract & $1.0,2.0 \mathrm{~g} \mathrm{~kg}^{-1}$ & Wistar rats & $\begin{array}{l}\text { It has antagonistic effect on adjuvant arthritis in } \\
\text { rats, and its mechanism may be related to the } \\
\text { inhibition of immune function }\end{array}$ & $\begin{array}{l}\text { Kuang and } \\
\text { Liu (2002) }\end{array}$ \\
\hline \multirow[t]{6}{*}{ Anti-tumor } & Husks & Xanifolia Y & $2.5,5$, and $10 \mathrm{mM}$ & $\begin{array}{l}\text { HepG2, } \\
\text { HCT116, } \\
\text { and U87-MG } \\
\text { cell lines }\end{array}$ & $\begin{array}{l}\text { It could suppress U87-MG cell proliferation by } \\
\text { inducing apoptosis in the early period of exposure } \\
\text { and then promote arrest at the G0/G1 phase }\end{array}$ & $\begin{array}{l}\text { Wang et al. } \\
\text { (2016a) }\end{array}$ \\
\hline & Husks & Xanthoceraside & $10 \mu \mathrm{M}$ & $\begin{array}{l}\text { A375.S2 } \\
\text { cells }\end{array}$ & $\begin{array}{l}\text { Xanthoceraside selectively inhibits the } \\
\text { proliferation of human melanoma A375 cell line } \\
\text { and induces apoptosis through the } \\
\text { mitochondria-mediated apoptotic pathway }\end{array}$ & $\begin{array}{l}\text { Jiao et al. } \\
\text { (2014) }\end{array}$ \\
\hline & Husks & $\begin{array}{l}\text { 3-O-[ } \alpha \text {-L-arabinofuranosyl } \\
(1 \rightarrow 3)]-[\beta \text {-D- } \\
\text { galactopyranosyl }(1 \rightarrow 2)]- \\
\beta \text {-D-(6-O-n-butyl)- } \\
\text { glucuronopyranosyl-21, } \\
\text { 22-O-diangeloyl- } \mathrm{R}_{1} \text { - } \\
\text { barrigenol }\end{array}$ & 9.75 and $17.32 \mu \mathrm{M}$ & $\begin{array}{l}\text { HepG2, } \\
\text { HCT-116 } \\
\text { cell }\end{array}$ & $\begin{array}{l}\text { The compound showed significant inhibitory } \\
\text { activity against the proliferation of HepG2, HCT- } \\
116 \text { cell lines }\end{array}$ & $\begin{array}{l}\text { Wang et al. } \\
(2016 b)\end{array}$ \\
\hline & Wood & $\begin{array}{l}\text { 3-Oxotirucalla-7,24-dien- } \\
\text { 21-oic acid, oleanolic acid, } \\
\text { epicatechin }\end{array}$ & 20,10, and $70 \mu \mathrm{g} \mathrm{mL}^{-1}$ & HIV-1 PR & $\begin{array}{l}\text { They were found to be inhibitory substances } \\
\text { against human immunodeficiency virus (HIV-1) } \\
\text { protease }\end{array}$ & $\begin{array}{l}\text { Ma et al. } \\
(2000)\end{array}$ \\
\hline & Kernels & Total saponins & $9.7 \pm 0.39 \mathrm{mg} \mathrm{L}^{-1}$ & HepG2 cell & $\begin{array}{l}\text { Total saponins can induce apoptosis of HepG2 } \\
\text { cells. The flow cytometry showed that the late } \\
\text { apoptosis of cancer cells may be concentrated in } \\
\text { the } S \text { phase of cell cycle }\end{array}$ & $\begin{array}{l}\text { Zhang et al. } \\
(2016)\end{array}$ \\
\hline & Husks & 95\% Ethanol-water extract & $75 \mu \mathrm{g} \mathrm{mL}^{-1}$ & HepG2 cell & $\begin{array}{l}\text { When the mass concentration of } 95 \% \text { ethanol } \\
\text { water extract was } 75 \mathrm{\mu g} \mathrm{mL}^{-1} \text {, the inhibition of } \\
\text { HepG } 2 \text { cell proliferation effect was up to } 70.1 \%\end{array}$ & $\begin{array}{l}\text { Zhang et al. } \\
(2017)\end{array}$ \\
\hline \multirow[t]{7}{*}{ Anti-oxidation } & Wood & $\begin{array}{l}\text { Catechin, epicatechin, } \\
\text { myricetin, and } \\
\text { dihydromyricetin }\end{array}$ & $\begin{array}{l}6.5,4.2,3.8, \text { and } \\
5.7 \mu \mathrm{g} \mathrm{mL}^{-1}\end{array}$ & - & $\begin{array}{l}\text { These four compounds has been shown to } \\
\text { scavenge DPPH radicals, with } \mathrm{EC}_{50} \text { values of } 6.5 \text {, } \\
4.2,3.8 \text {, and } 5.7 \mu \mathrm{gL}^{-1} \text {, and afford remarkable } \\
\text { protection of peroxyl radical-induced DNA strand } \\
\text { scission, exhibiting protection values of } 92.10 \text {, } \\
94.66,75.44 \text {, and } 89.95 \% \text { at a concentration of } \\
10 \mu \mathrm{mol} \mathrm{L}^{-1}\end{array}$ & $\begin{array}{l}\text { Zhang et al. } \\
(2015)\end{array}$ \\
\hline & Husks & Total saponins & $50 \mu \mathrm{g} \mathrm{mL}^{-1}$ & $\begin{array}{l}\text { A549, } \\
\text { HepG2, } \\
\text { MGC-803, } \\
\text { and MFC cell } \\
\text { lines }\end{array}$ & $\begin{array}{l}\text { The total saponins have shown the ability to } \\
\text { scavenge hydroxyl free radicals and superoxide } \\
\text { anion free radicals; this scavenging ability } \\
\text { exhibited a dose-effect relationship with } \\
\text { concentration }\end{array}$ & $\begin{array}{l}\text { Yang et al. } \\
(2016 a)\end{array}$ \\
\hline & Seeds & Seed oil & $0.151,0.195 \mathrm{~g} \mathrm{~mL}^{-1}$ & - & $\begin{array}{l}\text { The seed oil exhibited notable DPPH radical- } \\
\text { scavenging activity and lipid peroxidation } \\
\text { inhibitory activity with } \mathrm{IC}_{50} \text { values of } 0.151 \text { and } \\
0.195 \mathrm{~g} \mathrm{~mL}^{-1}\end{array}$ & $\begin{array}{l}\text { Zhang et al. } \\
(2010)\end{array}$ \\
\hline & Husks & Saponins & $0.18-2.52 \mathrm{mg} \mathrm{mL}^{-1}$ & $\begin{array}{l}\text { The rate of } \\
\text { tyrosinase } \\
\text { catalyzed } \\
\text { L-DOPA } \\
\text { oxidation }\end{array}$ & $\begin{array}{l}\text { At a concentration of } 0.18-2.52 \mathrm{mg} \mathrm{mL}^{-1} \text {, the } \\
\text { hydroxyl radical-scavenging effect of the } \\
\text { saponins form } X . \text { sorbifolium husks was } \\
15.5-68.7 \%\end{array}$ & $\begin{array}{l}\text { Zhang and } \\
\text { Zhou (2013a) }\end{array}$ \\
\hline & Kernels & $\begin{array}{l}\text { Microwave-assisted } \\
\text { extraction extract of } \\
\text { triterpene saponins }\end{array}$ & $0.782 \mathrm{mg} \mathrm{mL}^{-1}$ & - & $\begin{array}{l}\text { Microwave-assisted extraction extract of } \\
\text { triterpene saponins exhibited substantial free } \\
\text { radical-scavenging activity with an IC50 value of } \\
0.782 \mathrm{mg} \mathrm{mL}^{-1}\end{array}$ & $\begin{array}{l}\text { Li et al. } \\
\text { (2010) }\end{array}$ \\
\hline & Seeds & Seed oil & $\begin{array}{l}0.11,0.22,0.33 \mathrm{ml} / \\
(20 \mathrm{~g} \mathrm{bw})\end{array}$ & $\begin{array}{l}\text { Male KM } \\
\text { mice }\end{array}$ & $\begin{array}{l}\text { The activities of antioxidant enzymes such as } \\
\text { SOD, CAT and GSH-Px in liver and brain of mice } \\
\text { in the cold pressing oil test group were } \\
\text { significantly higher than those in the normal } \\
\text { control group }\end{array}$ & $\begin{array}{l}\text { Deng et al. } \\
\text { (2010) }\end{array}$ \\
\hline & Seeds & Seed oil & $0.1-1.4 \mathrm{~g} \cdot \mathrm{mL}^{-1}$ & - & $\begin{array}{l}\text { Seed oil has a good scavenging effect on } \\
\text { hydroxyl radical and superoxide anion radical, } \\
\text { has a strong scavenging effect on DPPH radical, } \\
\text { and its reduction ability exceeds } \mathrm{BHT} \text { and } \mathrm{TBHQ} \text {. } \\
\text { It also has a good inhibitory effect on } \mathrm{Fe}^{2+} \\
\text { induced lipid peroxidation at higher concentration }\end{array}$ & $\begin{array}{l}\text { Deng et al. } \\
(2012)\end{array}$ \\
\hline
\end{tabular}


TABLE 2 | (Continued) The pharmaceutical effects of $X$. sorbifolium.

\begin{tabular}{|c|c|c|c|c|c|c|}
\hline $\begin{array}{l}\text { Pharmaceutical } \\
\text { effects }\end{array}$ & $\begin{array}{l}\text { Used } \\
\text { part }\end{array}$ & Compounds/extracts & Doses & Models & Results/mechanism & References \\
\hline & Husk & Ethanol extract & $0.2 \mathrm{mg} \cdot \mathrm{mL}^{-1}$ & - & $\begin{array}{l}\text { The ethanol extracts exhibited a scavenging } \\
\text { effect on DPPH, with the } 70 \% \text { ethanol aqueous } \\
\text { extract showing the strongest activity for } \\
\text { scavenging the DPPH free-radical at a } \\
\text { concentration of } 0.2 \mathrm{mg} \cdot \mathrm{mL}^{-1}\end{array}$ & $\begin{array}{l}\text { Zhang et al. } \\
(2017)\end{array}$ \\
\hline Antidepressant & Husks & Xanthoceraside & $\begin{array}{l}0.02,0.08 \text { and } \\
0.32 \mathrm{mg} \cdot \mathrm{kg}^{-1}\end{array}$ & $\begin{array}{l}\text { Adult male } \\
\text { C57BL/6J } \\
\text { mice }\end{array}$ & $\begin{array}{l}\text { Xanthoceraside possesses antidepressant } \\
\text { effects in mice which are mediated by activation } \\
\text { of hippocampal BDNF signaling pathway }\end{array}$ & $\begin{array}{l}\text { Guan et al. } \\
\text { (2021) }\end{array}$ \\
\hline Anti-HIV & $\begin{array}{l}\text { Seed } \\
\text { coat }\end{array}$ & Cleomiscosin B & $8.61-12.76 \mu \mathrm{g} \cdot \mathrm{mL}^{-1}$ & C8166 cell & $\begin{array}{l}\text { The cleomiscosin B have exhibited an effect on } \\
\text { HIV-1 IIIB-induced C8166 cell formation in } \\
\text { syncytia with an } \mathrm{EC}_{50} \text { of } 8.61-12.76 \mathrm{\mu g} \cdot \mathrm{mL}^{-1} \text {, as } \\
\text { well as a protective effect on MT4 cells infected by } \\
\text { HIV-1 IIIB. }\end{array}$ & $\begin{array}{l}\text { Li et al. } \\
\text { (2007b) }\end{array}$ \\
\hline
\end{tabular}

mechanism. Therefore, further in vivo experiments are needed to determine the effective chemical constituents and signal pathways and clarify the anti-cancer mechanism of $X$. sorbifolium.

\section{Antioxidant Activity}

Oxidative stress plays a crucial role in the pathogenesis of various chronic diseases, such as diabetes, cardiovascular diseases, and neurodegenerative diseases. ROS are often associated with oxidative stress. Scavenging or inhibiting ROS generation can delay or prevent oxidative cellular oxidizable substrates from achieving anti-oxidation (Uttara et al., 2009; Small et al., 2012; Zhao et al., 2018). In recent years, deeper investigations of $X$. sorbifolium have highlighted its antioxidant activity.

Zhang et al. (2015) reported that the compounds epicatechin, catechin, myricetin, and dihydromyricetin, which exist in lignum xanthocerais, showed remarkable protective effects against peroxyl radical-induced DNA strand scission (when the concentration was $10 \mu \mathrm{mol} \mathrm{L}{ }^{-1}$, the protective rates were 92.10 , 94.66, 75.44, and 89.95\%, respectively). Furthermore, some researchers have reported that saponins from the $X$. sorbifolium nutshell have a higher scavenging effect than vitamin $\mathrm{C}$ in vitro. The hydroxyl radical-scavenging effects of saponins were $15.5-68.7 \%$ at a concentration of 0.18-2.52 $\mathrm{mg} \mathrm{mL}^{-1}$ (Zhang and Zhou, 2013a). The antioxidant activity of crude extracts in ethanol extraction fractions of 10,30 , 50,70 , and $95 \%$ showed scavenging effects on DPPH with a dosedependent relationship. The $70 \%$ ethanol extract had the most substantial effect (the DPPH scavenging rate reached $70.82 \%$ at a mass concentration of $0.2 \mathrm{mg} \mathrm{mL}^{-1}$ ) (Zhang et al., 2017). These results also support the traditional use of treating metabolic syndromes, such as diabetes and hypertension.

As various studies have revealed the antioxidant activities of $X$. sorbifolium, this plant should be further explored for potential novel antioxidants. However, verification methods such as DPPH analysis may overestimate the antioxidant content. Moreover, these determination methods cannot characterize all the analytical properties of the extract (Amorati and Valgimigli, 2015). Therefore, these methods are not yet sufficient for elucidating the antioxidant mechanism of $X$. sorbifolium, and further research is required to investigate the kinetics of this mechanism.

\section{Other Pharmacological Activities}

Xanthoceras sorbifolium has other pharmacological activities, including anti-HIV, and plays protective roles in cardiovascular and cerebrovascular diseases (Ma et al., 2000; Li et al., 2007b; Jin et al., 2010; Zhang et al., 2013; Geng et al., 2014). Furthermore, it also inhibits the activities of pancreatic lipase and tyrosinase.

For example, 3-oxotirucalla-7, 24-dien-21-oic acid, oleanolic acid, and epigallocatechin- $(4 \beta \rightarrow 8,2 \beta \rightarrow O-7)$-epicatechin isolated from the methanol extract from lignum xanthocerais are inhibitors of $\mathrm{HIV}-1$ protease with $\mathrm{IC}_{50}$ values of 20,10 , and $70 \mu \mathrm{g} \mathrm{mL}^{-1}$, respectively (Ma et al., 2000). Li et al. (2007b) reported that the coumarin compound (cleomiscosin B) extracted from the seed coat possessed strong anti-HIV-1 activity in vitro. It also had a strong inhibitory effect on HIV1 IIIB-induced C8166 cell formation in the syncytia with an $\mathrm{EC}_{50}$ value of 8.61-12.76 $\mu \mathrm{g} \mathrm{mL}^{-1}$ and a selectivity index of greater than 15.67-23.23 (Li et al., 2007b). Xu et al. (2014) found that xanthoceraside can significantly improve cerebral artery ischemia-reperfusion injury in rats. Its mechanism may promote synaptic remodeling and/or reduce synaptic structural and functional damage (Xu et al., 2014). Geng et al. (2014) found that xanthoceraside significantly inhibits pancreatic lipase activity, and the maximum inhibitory rate can reach $87.5 \%$. Therefore, as a weight-loss factor, xanthoceraside has broad prospects as both healthy food and medicine (Geng et al., 2014). Moreover, flavonoids and saponins extracted from the husk of $X$. sorbifolium have been shown to exhibit inhibitory effects on tyrosinase. For example, the inhibition rate was $45 \%$ at a flavonoid concentration of $0.48 \mathrm{mg} \mathrm{mL}^{-1}$ and showed nonlinear changes (Zhang et al., 2013). Zhang et al. (2013) showed that the saponin extract inhibited tyrosinase and was noncompetitive at a concentration of $0.36 \mathrm{mg} \mathrm{mL}^{-1}$, where the inhibition rate reached $64.6 \%$ (Zhang et al., 2013). Therefore, extracting flavonoids and saponins from the husk of $X$. sorbifolium as whitening components is in line with the current development trend of exploiting natural compounds as 
beauty components and improves the economic value of agricultural byproducts.

In general, there are many studies on the pharmacological activities of triterpenoids in X. sorbifolium. It is worth noting that xanthoceraside has many biological activities, and it may become a candidate compound for the prevention and treatment of $\mathrm{AD}$ and related diseases (Chi et al., 2010). The effective parts or active components with anti-AD effects can be isolated from $X$. sorbifolium, which can be used to prepare functional foods or drugs to improve learning and memory and have the potential to become leading anti-AD drugs through further research and development. However, screening for bioactivity and evaluation of most other categories of compounds remains at the crude extract level. To date, only a few reports have investigated the chemical constituents, bioactivity, pharmacodynamic, and mechanisms of action of extracts from $X$. sorbifolium, which remain elusive.

\section{STRUCTURE-ACTIVITY RELATIONSHIPS}

In the process of summarizing the chemical composition and pharmacology of oleanane-type triterpenes in X. sorbifolium, the general structural properties of the extracts along with their biological activities have been investigated. Compounds with the same structural skeletons, but different types or positions of substituents have more significant impacts on cytotoxic activities. The triterpenoids with structural skeletons of R1barrigenol triterpenes were the active ingredients for anti-AD. Similarly, the barringtogenol $\mathrm{C}$ triterpenes and 16-deoxy barringtogenol $\mathrm{C}$ triterpenes were the active ingredients for anti-tumor activities. The triterpenes with no hydroxyl substitution at $\mathrm{C}_{15}$ and $\mathrm{C}_{16}$ showed no activity. Conversely, a hydroxyl substitution at $\mathrm{C}_{15}$ and $\mathrm{C}_{16}$ or $\mathrm{C}_{28}$ by a glycoside group displayed anti-tumor activity in vitro. However, if the hydroxyl substitution occurred at $\mathrm{C}_{24}$ or glycosylation at $\mathrm{C}_{3}$ and $\mathrm{C}_{21}$, the anti-tumor activity increased. In addition, angeloyl groups at $\mathrm{C}_{21}$ and $\mathrm{C}_{22}$ also play a role in inhibiting cell activity (Li 2006a; Wang et al., 2016b).

Regarding the relationship between the anti-AD activity and the structure of the ingredients, the most vigorous activity occurs in the compound R1-barrigenol. This activity disappears when its $\mathrm{C}_{3}$ is linked with a sugar group or when $\mathrm{C}_{24}$ is substituted with a hydroxyl group. Conversely, if ring A or $\mathrm{E}$ is substituted by a hydroxyl group, acetoxy group, or sugar chains, the activity of the compound decreases or disappears because of the different steric hindrance of $\mathrm{C}_{21} / \mathrm{C}_{22}$. For example, in compounds 22-di$O$-angeloyl-24-hydroxy- $\mathrm{R}_{1}$-barrigenol and 21-O-angeloyl-24hydroxy R1-barrigenol, if the angelic acyls substitute with either $C_{21}$ or $C_{22}$, the activity decreases. Therefore, when the activity occurs at $\mathrm{C}_{22}$, the activity decreases, and when the activity at $\mathrm{C}_{21}$ occurs, the activity vanishes. At both $\mathrm{C}_{21}$ and $\mathrm{C}_{22}$, the compound exhibits weak activity. Conversely, the substitution of a-hydroxyl at $\mathrm{C}_{15}$ or $\mathrm{C}_{16}$ can enhance activity ( $\mathrm{Li}, 2006 \mathrm{a}$ ). A study on the anti-tumor effects showed that saponins with the sugar chains at $\mathrm{C}_{3}$ and $\mathrm{C}_{21}$ exhibited significant cytotoxicity. When an acetoxy group and $\mathrm{C}_{28}$ substituted $\mathrm{C}_{22}$ with a hydroxyl group, the activity was enhanced. However, the activity decreased after exchanging the positions in the two substituent groups. Furthermore, the activity does not seem to be affected by $\mathrm{C}_{24}$ substitution (Chan, 2007). The structure of barrigenol-like triterpenoids greatly influences their activity. Thus, owing to its unique biological activity, $X$. sorbifolium has significant and far-reaching importance in the development of new natural antitumor and anti-AD drugs (Yu et al., 2012a).

\section{APPLICATIONS}

Xanthoceras sorbifolium is a multipurpose plant. All sections of the plant are edible, medicinal, economical, and of ecological value. The trunks and branches, fruits, leaves, and other parts contain natural products with rich structures, including a wide range of biological activities and pharmacological effects. Other sections are utilized as food in China, such as fruit, tea, and cooking oil. Xanthoceras sorbifolium has ornamental value and is useful for carbon storage, soil remediation, and water conservation. The plant can also be used as industrial raw materials.

\section{Traditional Applications}

As a traditional medicinal herb in China, X. sorbifolium has been used widely in traditional Chinese and Mongolian medicines. Various plant parts are used for medicine, including trunks and branches, leaves, fruits, seeds, and flowers. The different parts have different medicinal values. The trunks and branches, lignum xanthocerais, are also called "xi la sen deng" in traditional Mongolian medicine (Pharmacopoeia Committee of the Ministry of Health of the People's Republic of China, 1998). The therapeutic significance of lignum xanthocerais has been well acknowledged in the ancient Mongolian classics such as "Jing Zhu Ben Cao" (Qing Dynasty, AD 1848), "Meng Yao Zheng Dian" (Qing Dynasty, AD 19th), and "Chinese Materia Medica." (Demar, 1986) In the 1977 edition of the "Chinese Pharmacopeia," the folk remedies for the treatment of rheumatism with $X$. sorbifolium leaves were first recorded (Commission NP. 1977). It has been reported that it is sweetflavored cool-natured, and suitable to treat scurvy, rheumatism, rheumatoid arthritis, enuresis in children, rheumatic heart disease, swollen glands, overheating, and swelling, and also offers pain relief (Chinese Materia Medica Editorial Committee, 2004; Wang et al., 2011). In addition, fruits are used to treat rheumatism, gout, and enuresis in children as a folklore medicine in Inner Mongolia. It has been developed into a product named "Pediatric Urinary Suspension" by pharmaceutical companies (Zhao et al., 2008). According to the new Tibetan medicine formula, lignum xanthocerais is used in Liuweiximi pills in Tibet, China. It has the effects of tonifying the kidney, "expelling wind and dampness," relieving pain, and treating kidney and low back pain as well as frequent urination caused by kidney cold (Institute of Tibetan medicine, 1975). X. sorbifolium is also widely used in Northeast China. For example, its seeds are used to treat nocturia in children (Xie, 1996). Its fruit is mainly used for rheumatoid arthritis 
(Ministry of Health of Shenyang Army Logistics Department, 1970); its wood can dispel wind, remove dampness, detumescence, and relieve pain (National Administration of Traditional Chinese Medicine, 1999).

In summary, $X$. sorbifolium has a wide range of traditional uses, and most of its recorded traditional applications are concentrated in northern China. Effectively combining traditional applications of $X$. sorbifolium with modern clinical applications will be a notable future research direction.

\section{Clinical Applications}

Xanthoceras sorbifolium is rich in 278 compounds, providing a reasonable basis for medicinal use. The triterpenes isolated from the husk are promising candidates for medicines to prevent or cure human cancer, $\mathrm{AD}$, enuresis, urinary incontinence, dementia, and modulate cerebral functions (Ge and Wu, 1997; Liu et al., 2007a; Liu et al., 2007b; Chi et al., 2009; Lu et al., 2012; Li and Sun, 2019). The leaves are rich in saponin, flavonoids, protein, and trace elements, with a high inhibitory effect on various human tumor cells (such as breast cancer, prostate cancer, gastric cancer, liver cancer, cervical cancer, and leukemia). The leaves can improve the functions of the central nervous system, cholinergic nerve system and fight the damage caused by free radicals, assisting the treatment of urine incontinence and an overactive bladder ( $\mathrm{Si}, 1996)$. After degreasing, the kernels of $X$. sorbifolium can be made into efficient drugs to treat pediatric enuresis. The data from 100 initial clinical results show that its efficacy rate is as high as $93 \%$. In addition, lignum xanthocerais is often combined with other medicines in clinical preparations to treat skin diseases and rheumatism. The traditional and modern prescriptions of lignum xanthocerais are listed in Table 3.

Except for the anti-inflammatory activity, which has been widely used in clinical applications, most of the other pharmacological activities have only been studied theoretically; thus, they lack extensive practical research. Therefore, applying the pharmacological activity of $X$. sorbifolium to clinical practice should be the focus of future $X$. sorbifolium research.

\section{Edible Applications}

The food value of $X$. sorbifolium is mainly derived from its seeds, kernels, and leaves. Edible oil can be extracted from the seeds and the oil ratio is $30.4 \%$ in the seeds and $55-66 \%$ in the kernel (Yan, 2007). The oil is a cooking oil with a high smoke point, a yellowish color and delicious flavor and may help in preventing cardiovascular and cerebrovascular diseases. In the seed oil, the unsaturated fat has been isolated, accounting for $94.0 \%$, including linoleic acid (36.9\%) and oleic acid (57.16\%). (Yan, 2007; Zeng et al., 2013). The tender kernels have a unique fruit flavor that can be eaten raw or processed into canned food for giving to infants during weaning.

Additionally, kernels can also be processed into a nutritious fruit juice and a high-quality protein drink. Moreover, the seeds are delicious when fried ( $\mathrm{Li}$ et al., 2003). The leaves of $X$. sorbifolium can be processed for tea and lower blood lipids, blood pressure, and protect the cardiovascular and cerebrovascular vessels. In tea, the protein content is as high as $19.8-23.0 \%$, which is higher than black tea, and the caffeine content is similar to scented tea (Hua, 2004). The flower is a hardy honey plant with a long flowering period, enabling a large amount of honey to be produced from the flowers. The husk remaining after oil extraction can be made into high-protein beverages $(\mathrm{Li}$ et al., 2003).

\section{Other Applications}

In addition to its edible and medicinal uses, $X$. sorbifolium has a high economic and ecological value. The plant is a potential bioenergy feedstock plant and has been identified as a major woody energy species for biodiesel production. Producers receive special support from the Chinese government for its development. The whole plant can be used as an eco-friendly tree species for soil and water conservation and land reclamation in mining areas (Bai et al., 2010). The husk contains $12.2 \%$ furfural, which is the best raw material for furfural extraction. Husks and seed coats can be used as a source of activated carbon, xylitol, alcohol, and other chemical raw materials. The trunks and branches can be exploited as top-grade furniture and farm tools because of the hard texture, strong corrosion resistance, and dark maroon color with a beautiful vein pattern (Xu and Yu, 2010). The plant has a long flowering period with bright colored flowers making it highly ornamental. As an ornamental tree, it is suitable for planting in gardens, parks, and scenic areas (Wan et al., 2010). The flowers are also edible, and the pollen and oil can be used to make advanced beauty skincare products (Zhang et al., 2012).

\section{CONCLUSION AND DISCUSSION}

In conclusion, $X$. sorbifolium, a native plant with economic and medicinal value in China, is rich in resources and is widespread throughout northern China. Here, $X$. sorbifolium was reviewed with regard to botany, phytochemistry, pharmacological activity, structure-activity relationship, and applications. Concerning the phytochemistry of $X$. sorbifolium, a total of 278 compounds have been discovered: 124 terpenoids, 48 flavonoids, 14 phenylpropanoids, 17 steroids, 17 phenols, 29 fatty acids, 9 alkaloids, 4 quinones, and 16 other compounds. Modern pharmacology has gradually verified the traditional efficacy of $X$. sorbifolium and explored its role in treating $\mathrm{AD}$, rheumatism, vasculitis, scabies, and other diseases. The pharmacological effects have mostly focused on improving learning and memory impairment, as well as on anti-inflammatory and antioxidant effects. Nevertheless, there are still some research barriers that need to be overcome. Despite numerous studies on the chemical constituents of $X$. sorbifolium, research into the corresponding pharmacological activities predominantly involves terpenoids and saponins, especially the landmark compound xanthoceraside, which shows good pharmacological activity related to improving learning and memory impairment, antiinflammation, and anti-tumor properties. However, research into other types of compounds is very limited. Moreover, it is difficult to link the phytochemistry and pharmacological effects of $X$. sorbifolium; therefore, this should mark the main direction of future $X$. sorbifolium research. Furthermore, in the process of 
TABLE 3 | Traditional and modern prescriptions of lignum xanthocerais in China.

\begin{tabular}{|c|c|c|c|c|c|}
\hline No. & $\begin{array}{l}\text { Parts } \\
\text { used }\end{array}$ & Preparation name & $\begin{array}{l}\text { Mode of } \\
\text { preparation }\end{array}$ & $\begin{array}{l}\text { Traditionaland clinical } \\
\text { uses }\end{array}$ & References \\
\hline 1 & Wood & Sendeng Siwei Tangsan & Decoction & Arthritis and edema & Commission NP (1977); Li et al. (2013b) \\
\hline 2 & Wood & $\begin{array}{l}\text { WenGuanMu } \\
\text { Ershiwuwei Wan }\end{array}$ & Pill & Relieve rheumatic pains, remove paralysis, anti-inflammation & $\mathrm{Ba}(2007)$ \\
\hline 3 & Wood & $\begin{array}{l}\text { WenGuanMu Jiuwei } \\
\text { Decoction }\end{array}$ & Decoction & Relieve rheumatic pains, detumescence and purging fire & $\mathrm{Ba}(2007)$ \\
\hline 4 & Wood & $\begin{array}{l}\text { WenGuanMu Sanwei } \\
\text { Decoction }\end{array}$ & Decoction & $\begin{array}{l}\text { Relieve rheumatic pains, clear heat and detoxify, anti- } \\
\text { inflammation, moisturize skin }\end{array}$ & Si (1996) \\
\hline 5 & Wood & WenGuanMu Ruangao & Uunguent & Used for psoriasis, neurodermatitis, and other skin diseases & Commission NP (1977) \\
\hline 6 & Wood & $\begin{array}{l}\text { Sendeng.Ji ri gan } \\
\text { Decoction }\end{array}$ & Decoction & Used for rheumatoid arthritis and brucellosis & Meng (1991) \\
\hline 7 & Wood & Sendeng.Manmari & Pill & $\begin{array}{l}\text { Relieve rheumatic pains, clear heat and detoxify. Used for } \\
\text { rheumatism and scabies }\end{array}$ & Meng (1991) \\
\hline 8 & Wood & Sendeng.nai ma & Pill & $\begin{array}{l}\text { Relieve rheumatic pains, clear heat and detoxify. Used for } \\
\text { rheumatism, brucellosis, and scabies }\end{array}$ & Meng (1991) \\
\hline 9 & Wood & $\begin{array}{l}\text { Sendeng.Duriben } \\
\text { Decoction }\end{array}$ & Decoction & $\begin{array}{l}\text { Relieve rheumatic pains, clear heat and detoxify. Used for } \\
\text { rheumatic fever }\end{array}$ & Meng (1991) \\
\hline 10 & Wood & Shendeng Handa & Unguent & $\begin{array}{l}\text { Clear heat. Used for Rheumatism, rheumatoid, joint swelling and } \\
\text { pain, eczema and other skin diseases }\end{array}$ & $\begin{array}{l}\text { Inner Mongolia Autonomous Region } \\
\text { Health Department (1984) }\end{array}$ \\
\hline
\end{tabular}

studying the structure-activity relationships of $X$. sorbifolium, it was discovered that the biological activities of compounds with the same structural skeleton but different substituent positions have significant differences, especially in their anti-tumor and anti-AD properties. More research into the structure-activity relationships of $X$. sorbifolium will be highly significant for the development and utilization of these compounds. In addition, no studies have yet reported any differences in the main production areas or seasons for the same plant component.

Despite the substantial practical value of $X$. sorbifolium, current research is not comprehensive. It requires further analysis of five main aspects to fully understand all the characteristics of $X$. sorbifolium. First, 278 compounds were isolated from $X$. sorbifolium, most of which were terpenoids. However, a lot of unknown compounds are yet to be found. The bioactivity-oriented separation strategy can be used to study potential phytochemicals and explore target compounds. However, the difficulty of phytochemical separation and the low content of compounds limit drug development. In general, using abundant phytochemicals to develop potential compounds can lay a foundation for developing new drugs. Some active derivatives should be considered to enrich the medicinal value of $X$. sorbifolium. Second, there is currently no standard quality control method or index for assessing the components of $X$. sorbifolium. Therefore, considerable research should be devoted to creating a standard quality assessment approach to ensure the quality of $X$. sorbifolium. Specifically, it is necessary to determine $X$. sorbifolium contents or produce standardized fingerprints to index the components of this species. Third, research on the biological activity of the compounds remains limited, with the majority of selected biological activity research employing only the crude extract. Therefore, more studies are required to assess the pharmacodynamic material and pharmacological mechanisms to obtain relevant compounds responsible for the pharmacological effects and unveil the potential mechanisms involved. In addition, research on the antioxidant activity of $X$. sorbifolium is mostly based on chemical methods such as DPPH experiments, which are not particularly thorough, making it difficult to reveal the antioxidant mechanism of $X$. sorbifolium. We believe that $X$. sorbifolium can become an excellent antioxidant; however, sufficient in vivo and in vitro studies are required to support this development. Fourth, additional pharmacokinetic, metabolomic, and clinical studies are required to elucidate all chemical constituents entering the body and their processes within the body. Such research would aim to build a bridge between the chemical constituents and the systemic clinical effects, which is crucial for fully understanding the target components, pharmacological effects, and potential applications of this plant. Fifth, at present, there is little comprehensive utilization of $X$. sorbifolium resources, especially the research and utilization of teamaking technology, drinking methods, and health products based on the leaves, which still have a great potential for development and value-added utilization. Furthermore, the oil production from $X$. sorbifolium generates large volumes of waste, including husks, oil residue, seed meals, and seed coats. Research has shown that the residues are rich in various compounds. There is an urgent need to create new technological systems to develop and utilize these waste products to add value and create societal benefits.

In summary, this review provides a comprehensive and critical analysis of the phytochemistry, pharmacology, and traditional and modern applications of $X$. sorbifolium. We also discuss the limitations of existing literature and propose solutions for further research and development. Finally, we summarize and analyze the importance of $X$. sorbifolium for medicinal applications.

\section{DATA AVAILABILITY STATEMENT}

The original contributions presented in the study are included in the article/Supplementary Material, further inquiries can be directed to the corresponding author. 


\section{AUTHOR CONTRIBUTIONS}

ML conceived the review. EZ, BQ, NC, and CL drafted the manuscript. QL, MZ, YL was involved in the editing process. All authors read and approved the final version of the manuscript.

\section{REFERENCES}

Aderogba, M. A., Ndhlala, A. R., Rengasamy, K. R., and Van Staden, J. (2013). Antimicrobial and Selected In Vitro Enzyme Inhibitory Effects of Leaf Extracts, Flavonols and Indole Alkaloids Isolated from croton Menyharthii. Molecules 18 (10), 12633-12644. doi:10.3390/molecules181012633

Amorati, R., and Valgimigli, L. (2015). Advantages and Limitations of Common Testing Methods for Antioxidants. Free Radic. Res. 49 (5), 633-649. doi:10.3109/10715762.2014.996146

Ba, G. N. (2007). Mongolian Medicine Prescription. Hohhot, China: Inner Mongolia People's Publishing Press, 128-137.

Bai, D. D., Liu, R. X., Hu, C. Y., Li, Y. H., and Yin, S. N. (2010). Research on Seedlings Transplanted Technique of Xanthoceras Sorbifolia Bunge in Shandong Mining Area. J. Inner Mongolia Agr. Univ. 31, 72-76.

Bao, X., Go, Y., Yu, R., Li, W. M., Yang, N., and Zhu, H. N. (2012). Determination of Fatty Acids in the Seed Kernel Oil of Xanthoceras Sorbifolia Bunge by Precolumn-HPLC Derivatization. North. Pharma 9 (1), 3-4.

Chan, P. K. (2007). Acylation with Diangeloyl Groups at C21-22 Positions in Triterpenoid Saponins Is Essential for Cytotoxicity towards Tumor Cells. Biochem. Pharmacol. 73 (3), 341-350. doi:10.1016/j.bcp.2006.10.007

Chan, P. K., Zhao, M., Che, C. T., and Mak, E. (2008). Cytotoxic Acylated Triterpene Saponins from the Husks of Xanthoceras Sorbifolia. J. Nat. Prod. 71, 1247-1250. doi:10.1021/np070577v

Chen, G., Xie, Y., Zhou, D., Yang, L., Zou, L., Cheng, M., et al. (2020a). In Vivo evaluation and Atom-Based 3D-QSAR Studies on Saponins from Shells of Xanthoceras Sorbifolium Bunge as Anti-AD Agents. Bioorg. Chem. 94, 103412. doi:10.1016/j.bioorg.2019.103412

Chen, G., Xie, Y., Zhou, D., Yang, Y., Liu, J., Hou, Y., et al. (2020b). Chemical Constituents from Shells of Xanthoceras Sorbifolium. Phytochemistry 172, 112288. doi:10.1016/j.phytochem.2020.112288

Chen, Y. J., Takeda, T., Ogihara, Y., and Iitaka, Y. (1984). Studies on the Constituents of Xanthoceras Sorbifolia Bunge. II. Major Sapogenol and a Prosapogenin from the Fruits of Xanthoceras Sorbifolia Bunge. Chem. Pharm. Bull. (Tokyo) 32 (2), 3378-3383. doi:10.1248/cpb.32.3378

Chen, Y., Takeda, T., and Ogihara, Y. (1985a). Studies on the Constituents of Xanthoceras Sorbifolia Bunge. III. Minor Prosapogenins from the Fruits of Xanthoceras Sorbifolia Bunge. Chem. Pharm. Bull. 33 (1), 127-134. doi: $10.1248 / \mathrm{cpb} .33 .127$

Chen, Y., Takeda, T., and Ogihara, Y. (1985b). Studies on the Constituents of Xanthoceras Sorbifolia Bunge. IV. Structures of the Minor Prosapogenins. Chem. Pharm. Bull. 33 (3), 1043-1048. doi:10.1248/cpb.33.1043

Chen, Y., Takeda, T., and Ogihara, Y. (1985c). Studies on the Constituents of Xanthoceras Sorbifolia Bunge. V. Major Saponins from the Fruits of Xanthoceras Sorbifolia Bunge. Chem. Pharm. Bull. 33 (4), 1387-1394. doi:10.1248/cpb.33.1387

Cheng, W. M., Yang, B. Z., and Li, C. R. (2001). Two New Sterols in the Husk of Xanthoceras Sorbifolia. Chin. Tradit. Herb. Drugs 32, 199-201. doi:10.3321/ j.issn:0253-2670.2001.03.004

Cheng, W. M., Yang, B. Z., and Li, J. (2002). Fatty Acids in the Husk of Xanthoceras Sorbifolia Bunge. Anhui Med. Pharm. J. 6 (4), 5-6. doi:10.3969/j.issn.10096469.2002.04.003

Chi, T.-Y., Wang, L.-H., Ji, X.-F., Shen, L., and Zou, L.-B. (2013). Protective Effect of Xanthoceraside against $\beta$-amyloid-induced Neurotoxicity in Neuroblastoma SH-Sy5y Cells. J. Asian Nat. Prod. Res. 15, 1013-1022. doi:10.1080/ 10286020.2013.821982

Chi, T. Y., Wang, L. H., Qu, C., Yang, B. Z., Ji, X. F., Wang, Y., et al. (2009). Protective Effects of Xanthoceraside on Learning and Memory Impairment

\section{FUNDING}

This work was supported by 2019 Chinese medicine public health service subsidy special "the fourth survey on Chinese materia medica resource" (Grant No. Finance Society (2019) 39), China Agriculture Research System (Grant No. CARS-21).

Induced by Abeta(25-35) in Mice. J. Asian Nat. Prod. Res. 11, 1019-1027. doi:10.1080/10286020903337832

Chi, T. Y., Wang, L. H., Ji, X. F., Li, W., Wang, Y., and Zou, L. B. (2010). Protective Effect of Xanthoceraside on Learning and Memory Impairment Induced by Intracerebroventricular Injections of $\mathrm{A} \beta_{1-42}$ in Mice. J. Shenyang Pharm. Univ. 27 (4), 314-319. doi:10.14066/j.cnki.cn21-1349/r.2010.04.011

Chinese Materia Medica Editorial Committee (2004). Chinese Materia Medica. Shanghai, China: Shanghai Sci. Tech. Press, 132-133.

Chirva, V. Y., and Kintya, P. K. (1971). The Structure of Xanthoceras Saponin. Khim. Prir. Soedin. 7 (4), 442-444. doi:10.1007/bf00564728

Commission NP (1977). Pharmacopoeia of the People's Republic of China. Beijing, China: Chem. Ind. Publishing Agency, 121-122.

Cui, H., Xiao, H., Ran, X. K., Li, Y. Y., Dou, D. Q., and Kang, T. G. (2012). Two New Oleanane-type Pentacyclic Triterpenoid Saponins from the Husks of Xanthoceras Sorbifolia Bunge. J. Asian Nat. Prod. Res. 14 (3), 216-223. doi:10.1080/10286020.2011.641954

Demar, D. (1986). Jing Zhu Ben Cao. Shanghai, China: Shanghai Sci. Tech. Publishers, 74 .

Deng, H., Fan, X., and Tian, Z. (2010). Antioxidation Effect of Cold Pressed Oil of Xanthoceras Sorbifolia Bunge Seed In Vivo. Chin. Oils Fats. 35 (12), 38-40. doi:10.3969/j.issn.1003-7969.2012.01.007

Deng, H., Tian, Z. Q., Fan, X. C., Guo, Y. R., and Qiu, N. X. (2012). Antioxidation Activity In Vitro of Cold Pressed Xanthoceras Sorbifolia Bunge Kernel Oil. Chin. Oils Fats. 37 (1), 28-32.

Ding, K., Guo, S., Rong, W., Li, Q., Liu, R., Xu, H., et al. (2019). A New Oleanane Type Pentacyclic Triterpenoid Saponin from the Husks of Xanthoceras Sorbifolium Bunge and its Neuroprotection on PC12 Cells Injury Induced by A $325-35$. Nat. Prod. Res. 34 (22), 3212-3218. doi:10.1080/14786419.2018.1557172

Dong, Y., Wang, H. W., Chen, C. J., Zhao, G. D., and Guan, H. B. (2008). Chemical Compositions of Lignum Xanthoceratis. J. Beijing Univ. Tradit. Chin. Med. 31 (12), 844-846. doi:10.3321/j.issn:1006-2157.2008.12.014

Editorial Board of Flora of China (1985). Flora of China, 47. Beijing, China: Science Press, 72.

Fan, X., Deng, H., Li, Z., Wang, C., and Zhang, Y. (2009). Functional Properties and Amino Acid Composition of Xanthoceras Sorbifolia Bunge Protein. Chin. Oils Fats. 34, 26-30. doi:10.1016/S1874-8651(10)60084-1

Fu, H., Guo, Y., Li, W., Dou, D., Kang, T., Koike, K., et al. (2010). A New Angeloylated Triterpenoid Saponin from the Husks of Xanthoceras Sorbifolia Bunge. J. Nat. Med. 64, 80-84. doi:10.1007/s11418-009-0359-z

Ge, H. Q., Wan, G. S., Wang, D., Wu, J. M., Sun, B. H., Wu, L. J., et al. (2016). Two New Isoxazolines from the Husks of Xanthoceras Sorbifolia Bunge. J. Asian Nat. Prod. Res. 18 (8), 744-751. doi:10.1080/10286020.2016.1167045

Ge, X., and Wu, L. J. (1997). Clinical Observation on 120 Cases of Diabetes Treated by Xanthoceras Sorbifolia. Chin. J. Nat. Med. 1, 12.

Geng, J., Zhang, H. M., and Zhou, Q. C. (2014). Inhibitory Effect of Xanthoceras Sorbifolia Nutshell Saponin on Pancreatic Lipase. Mod. Food Sci. Tech. 30 (11), 89-92. doi:10.13982/j.mfst.1673-9078.2014.11.017

Guan, W., Gu, J.-H., Ji, C.-H., Liu, Y., Tang, W.-Q., Wang, Y., et al. (2021). Xanthoceraside Administration Produces Significant Antidepressant Effects in Mice through Activation of the Hippocampal BDNF Signaling Pathway. Neurosci. Lett. 757, 135994. doi:10.1016/j.neulet.2021.135994

Guo, Y., Dou, D. Q., Kang, T. G., Wang, S. C., and Kuang, H. X. (2009). Structure Elucidation and Complete NMR Spectral Assignments of Two New Oleananetype Pentacyclic Triterpenoid Saponins from the Husks of Xanthoceras Sorbifolia Bunge. Magn. Reson. Chem. 47, 982-988. doi:10.1002/mrc.2479

Hao, D.-C., Hou, X.-D., Gu, X.-J., Xiao, P.-G., and Ge, G.-B. (2021). Ethnopharmacology, Chemodiversity, and Bioactivity of Cephalotaxus Medicinal Plants. Chin. J. Nat. Medicines 19 (5), 321-338. doi:10.1016/ S1875-5364(21)60032-8 
Hua, C. L. (2004). Xanthoceras Nutrient and Comprehensive Processing. Food Inform. Technol. 8, 26-27.

Huang, X., Atwood, C. S., Hartshorn, M. A., Multhaup, G., Goldstein, L. E., Scarpa, R. C., et al. (1999). The A Beta Peptide of Alzheimer's Disease Directly Produces Hydrogen Peroxide through Metal Ion Reduction. Biochemistry 38, 7609-7616. doi:10.1021/bi990438f

Huang, Y. F., and Feng, X. Z. (1987). Chemical Constituents of Xanthoceras Sorbifolia Bunge (I). Chin. Trad. Herb. Drugs 18 (5), 7-10.

Inner Mongolia Autonomous Region Health Department (1984). Inner Mongolia Mongolian Medicine Standard. Chifeng, China: Inner Mongolia Sci. Tech. Press, 377.

Institute of Tibetan medicine (1975). New Tibetan Medicine Formula. Lhasa, China: The Tibet people's Publishing House.

Ji, X. F., Chi, T. Y., Liu, P., Li, L. Y., Xu, J. K., Xu, Q., et al. (2017). The Total Triterpenoid Saponins of Xanthoceras Sorbifolia Improve Learning and Memory Impairments through against Oxidative Stress and Synaptic Damage. Phytomedicine 25, 15-24. doi:10.1016/j.phymed.2016.12.009

Ji, X. F., Chi, T. Y., Xu, Q., He, X. L., Zhou, X. Y., Zhang, R., et al. (2014). Xanthoceraside Ameliorates Mitochondrial Dysfunction Contributing to the Improvement of Learning and Memory Impairment in Mice with Intracerebroventricular Injection of A $\beta 1-42$. Evid. Based Complement. Alternat Med. 2014, 1-11. doi:10.1155/2014/969342

Jiao, Q., Zou, L., Liu, P., Xu, Q., Zhang, Y., Yu, Y., et al. (2014). Xanthoceraside Induces Apoptosis in Melanoma Cells through the Activation of Caspases and the Suppression of the IGF-1R/Raf/MEK/ERK Signaling Pathway. J. Med. Food 17 (10), 1070-1078. doi:10.1089/jmf.2013.3035

Jin, S. N., Wen, J. F., Kim, H. Y., Kang, D. G., Lee, H. S., Cho, K. W., et al. (2010). Vascular Relaxation by Ethanol Extract of Xanthoceras Sorbifolia via Akt- and SOCE-eNOS-cGMP Pathways. J. Ethnopharmacol. 132, 240-245. doi:10.1016/ j.jep. 2010.08 .007

Jung Joo, Y., Byung Hyuk, H., Eun Sik, C., Seung, N., Da Hye, J., Yun Jung, L., et al. (2018). Involvement of Heme Oxygenase-1 Induction in Anti-vascular Inflammation Effects of Xanthoceras Sorbifolia in Human Umbilical Vein Endothelial Cells. J. Tradit Chin. Med. 38 (6), 803-814. doi:10.1016/S0254-6272(18)30979-8

Kang, Y.-X., Zhang, H.-C., Wang, P., Liu, J.-J., and Ma, Y.-M. (2012). Chemical Constituents of the Leaves from Xanthoceras Sorbifolia. Chem. Nat. Compd. 48 (5), 875-876. doi:10.1007/s10600-012-0407-x

Keawsard, S., Natakankitkul, S., Liawruangrath, S., Teerawutgulrag, A., Trisuwan, K., Charoenying, P., et al. (2012). Anticancer and Antibacterial Activities of the Isolated Compounds from Solanum Spirale Roxb. Leaves. Chiang Mai. J. Sci. 39, 445-454.

Kuang, R., Bao, W. F., Zhao, M. H., An, N. F., and Liu, Y. L. (2001). The Anti Inflammatory Effects of the N-Butanol Extract of Xanthoceras Sorbifolia Bunge. J. Shenyang Pharm. Univ. 18 (1), 53-56. doi:10.3969/j.issn.10062858.2001.01.017

Kuang, R., and Liu, Y. (2002). Effects of N-Butanol Extract of Xanthoceras Sorbifolia Bunge on Rat Model with Adjuvant Arthritis and its Mechanism. Trad. Chin. Drug Res. Clin. Pharm. 13, 229-231. doi:10.19378/j.issn.10039783.2002.04.013

Li, J., Zu, Y. G., Luo, M., Gu, C. B., Zhao, C. J., Efferth, T., et al. (2013a). Aqueous Enzymatic Process Assisted by Microwave Extraction of Oil from Yellow Horn (Xanthoceras Sorbifolia Bunge.) Seed Kernels and its Quality Evaluation. Food Chem. 138, 2152-2158. doi:10.1016/j.foodchem.2012.12.011

Li, J. J., and Sun, L. (2019). Clinical Application of Mongolian Medicine Sendeng-4 Decoction. J. Med. Pharm. Chin. Minorities. 25 (4), 28-29. doi:10.16041/ j.cnki.cn15-1175.2019.04.01710.1007/s11655-019-3046-2

Li, J., Zu, Y.-G., Fu, Y.-J., Yang, Y.-C., Li, S.-M., Li, Z.-N., et al. (2010). Optimization of Microwave-Assisted Extraction of Triterpene Saponins from Defatted Residue of Yellow Horn (Xanthoceras Sorbifolia Bunge.) Kernel and Evaluation of its Antioxidant Activity. Innovative Food Sci. Emerging Tech. 11, 637-643. doi:10.1016/j.ifset.2010.06.004

Li, N., Wang, Y., Li, X., Zhang, H., Zhou, D., Wang, W., et al. (2016a). Bioactive Phenols as Potential Neuroinflammation Inhibitors from the Leaves of Xanthoceras Sorbifolia Bunge. Bioorg. Med. Chem. Lett. 26, 5018-5023. doi:10.1016/j.bmcl.2016.08.094

Li, R. P., Zhang, Y. X., and Wang, X. (2003). The Key Species for Returning farmland to forest in Arid and Semi-arid Areas of Northern China-Xanthoceras Sorbifolia. Hebei For. Sci. Technol. 21, 51.
Li, S. R., Zhang, W. T., and Tian, Z. (2013b). Experimental Study about Mongolian Medicine Sendeng-4 on Collagen-Induced Arthritis in Rats. J. Inner Mongolia Med. Univ. 35 (6), 479-483. doi:10.16343/j.cnki.issn.2095-512x.2013.06.004

Li, S. S., and Zhu, Y. (2012). Research Progress of Anti-inflammatoy Action in Active Ingredient of Chinese Drugs. Chin. Arch. Tradit. Chin. Med. 30, 143-146. doi:10.13193/j.archtcm.2012.01.145.lishsh.05910.1002/cjoc.201290027

Li, W., Li, X., Meng, D. L., Zhang, P., and Li, Z. L. (2007d). Two New Triterpenoids from the Carpophore of Xanthoceras Sorbifolia Bunge. J. Asian Nat. Prod. Res. 9, 7-11. doi:10.1080/10286020500289386

Li, W., Li, X., Yang, J., Li, L. H., Li, N., Meng, D. L., et al. (2006c). Two New Triterpenoids from the Carpophore of Xanthoceras Sorbifolia Bunge. Pharmazie 61, 810-811. doi:10.1080/10286020500289386

Li, W., Li, X., Yang, J., Meng, D. L., and Li, N. (2008). Two New Triterpenoid Saponins from the Carpophore of Xanthoceras Sorbifolia Bunge. J. Asian Nat. Prod. Res. 10 (3), 285-290. doi:10.1080/1028602070160522410.1080/ 10286020701782692

Li, W., Lu, Q., Li, X., Liu, H., Sun, L., Lu, X., et al. (2020). Anti-Alzheimer’s Disease Activity of Secondary Metabolites from Xanthoceras Sorbifolia Bunge. Food Funct. 11 (3), 2067-2079. doi:10.1039/c9fo01138b

Li, W., and Li, X. (2008). Chemical Constituents in Carpophore of Xanthoceras Sorbifolia. Chin. Trad. Herb. Drugs 39 (3), 335-337. doi:10.3321/j.issn:02532670.2008.03.005

Li, W., Li, X., Li, Z. L., Zhang, P., Xu, J., Wang, Y., et al. (2005a). Chemical Constituents of the Carpohore of Xanthoceras Sorbifolia Bunge. J. Shenyang Pharm. Univ. 22 (5), 345-347. doi:10.3969/j.issn.1006-2858.2005.05.008

Li, W., and Li, X. (2014). Triterpenoid Saponins from the Carpophore of Xanthoceras Sorbifolia. Chem. Nat. Compd. 50 (1), 100-102. doi:10.1007/ s10600-014-0876-1

Li, Y., Xu, J., Xu, P., Song, S., Liu, P., Chi, T., et al. (2016b). Xanthoceras Sorbifolia Extracts Ameliorate Dendritic Spine Deficiency and Cognitive Decline via Upregulation of BDNF Expression in a Rat Model of Alzheimer's Disease. Neurosci. Lett. 629, 208-214. doi:10.1016/j.neulet.2016.07.011

Li, Y., Wang, J., Sheng, J. G., Liu, L., Barger, S. W., Jones, R. A., et al. (1998). S100 $\beta$ Increases Levels of $\beta$-Amyloid Precursor Protein and its Encoding mRNA in Rat Neuronal Cultures. J. Neurochem. 71, 1421-1428. doi:10.1046/j.14714159.1998.71041421.x

Li, Y. Y., Xiang, Z., Cui, H., Xiao, H., Kang, T. G., Dou, D. Q., et al. (2013c). Two New Oleanane-type Saponins from the Husks of Xanthoceras Sorbifolia Bunge. Nat. Prod. Res. 27 (3), 208-214. doi:10.1080/14786419.2012.666748

Li, Z.-L., Zhao, D.-D., and Li, D.-Y. (2018). Spiro-isoxazolines from the Flowers of Xanthoceras Sorbifolia. Phytochemistry Lett. 28, 149-152. doi:10.1016/ j.phytol.2018.10.009

Li, Z. L., Li, D. Y., He, X. M., and Hua, H. M. (2013d). Two New Triterpenoid Saponins from the Husks of Xanthoceras Sorbifolia. Nat. Prod. Res. 27 (3), 232-237. doi:10.1080/14786419.2012.671316

Li, Z. L., Li, D. Y., Li, X., Li, N., and Meng, D. L. (2006b). [A New Alkaloid from the Husk of Xanthoceras Sorbifolia]. Yao Xue Xue Bao 41 (12), 1197-1200. doi:10.16438/j.0513-4870.2006.12.016

Li, Z. L., Li, X., Li, D. Y., Li, D., Meng, D. L., Li, W., et al. (2007c). Triterpenoid Prosapogenols and Prosapogenins from the Husks of Xanthoceras Sorbifolia. J. Asian Nat. Prod. Res. 9 (4), 387-392. doi:10.1080/10286020600782017

Li, Z. L., Li, X., Li, L. H., Li, N., Yu, M., Meng, D. L., et al. (2005b). Two New Triterpenes from the Husks of Xanthoceras Sorbifolia. Planta Med. 71, 1068-1070. doi:10.1055/s-2005-873108

Li, Z. L., Bing, L., Fan, C., Li, F. L., and Zou, K. (2007a). Studies on the Chemical Constituents of the Spermoderm of Xanthoceras Sorbifolia Bunge. Lishizhen Med. Materia. Med. Res. 18 (6), 1329-1330. doi:10.3969/j.issn.1008-0805.2007.06.025

Li, Z. L., Li, F. L., Zhang, Y. T., Zou, K., Zhang, X. J., Wang, J. Z., et al. (2007b). Inhibitory Activities against HIV-1 of Coumarins from the Seed coats of Xanthoceras Sorbifolia Bunge. J. Beijing For. Univ. 29 (5), 73-83. doi:10.13332/j.1000-1522.2007.05.010

Li, Z. L. (2006a). Study on the Chemical Composition and Biological Activity of the Husks of Xanthoceras Sorbifolia Bunge [dissertation]. Shenyang, China: Shenyang Pharmaceutical University.

Liang, Q., Fang, H., Liu, J., Zhang, B., Bao, Y., Hou, W., et al. (2021). Analysis of the Nutritional Components in the Kernels of Yellowhorn (Xanthoceras Sorbifolium Bunge) Accessions. J. Food Compost. Anal. 100 (3), 103925. doi:10.1016/j.jfca.2021.103925 
Lin, Z. L., Li, X., and Zhang, P. (2004). Research Progress in the Chemical Constituents and Pharmacological Activities of Xanthoceras Sorbifolia Bunge. J. Shenyang Pharm. Univ. 21 (6), 472-475. doi:10.1016/S08986568(03)00096-2

Liu, P., Zou, L., Jiao, Q., Chi, T., Ji, X., Qi, Y., et al. (2013). Xanthoceraside Attenuates Learning and Memory Deficits via Improving Insulin Signaling in STZ-Induced AD Rats. Neurosci. Lett. 543, 115-120. doi:10.1016/ j.neulet.2013.02.065

Liu, X. X., Ji, X. F., Lu, L. L., Yang, B. Z., Wang, L. H., Zou, L. B., et al. (2007a). Improvement of Ethanol Extract from Husk of Xanthoceras Sorbifolia Bunge on Rats with Learning and Memory Dysfunction. Chin. Tradit. Herb. Drugs 38 (12), 1859-1861. doi:10.3321/j.issn:0253-2670.2007.12.034

Liu, X. X., Yang, X. A., Qu, C., Wu, Z., Yang, B. Z., Wang, L. H., et al. (2007b). Effects of Extracts from the Pericarp of Xanthoceras Sorbifolia Bunge on Learning and Memory Obstacle. Tradit. Chin. Drug Res. Clin. Pharma. 18, 23-25. doi:10.19378/j.issn.1003-9783.2007.01.008

Lu, P., Mamiya, T., Lu, L., Mouri, A., Ikejima, T., Kim, H. C., et al. (2012). Xanthoceraside Attenuates Amyloid $\beta$ Peptide25-35-Induced Learning and Memory Impairments in Mice. Psychopharmacology (Berl) 219, 181-190. doi:10.1007/s00213-011-2386-1

Ma, C., Nakamura, N., Hattori, M., Kakuda, H., Qiao, J., Yu, H., et al. (2000). Inhibitory Effects on HIV-1 Protease of Constituents from the wood of Xanthoceras Sorbifolia. J. Nat. Prod. 63, 238-242. doi:10.1021/np9902441

Ma, C. M., and Nakamura, N. (2004). A Novel Protoilludane Sequiterpene from the wood of Xanthoceras Sorbifolia Bunge. Chin. Chem. Lett. 15 (1), 65-67.

Ma, T., and Klann, E. (2012). Amyloid $\beta$ : Linking Synaptic Plasticity Failure to Memory Disruption in Alzheimer's Disease. J. Neurochem. 120 Suppl 1, 140-148. doi:10.1111/j.1471-4159.2011.07506.x

Manthey, J. A., and Guthrie, N. (2002). Antiproliferative Activities of Citrus Flavonoids against Six Human Cancer Cell Lines. J. Agric. Food Chem. 50, 5837-5843. doi:10.1021/jf020121d

Meng, G. (1991). VALERIANELLA Miller. J. Shizhen Guoyi Guoyao. 2, 84. doi:10.1016/b978-0-444-89215-7.50119-6

Ministry of Health of Shenyang Army Logistics Department (1970). The Handbook of Chinese Herbal Medicine Commonly Used in Northeast China. Shenyang, China: Xinhua Bookstore of Liaoning Province.

Mou, H. X., Yu, H. Y., and Hou, X. C. (2008). Regular Distribution of Woody Energy Plant Xanthoceras Sorbifolia Bunge in China. J. Anhui Agri. Sci. 36 (9), 3626-3628. doi:10.13989/j.cnki.0517-6611.2008.09.151

National Administration of Traditional Chinese Medicine (1999). Chinese Materia Medica. Shanghai, China: Shanghai Scientific \& Technical Publishers.

Ni, H. Y., and Zhang, Z. H. (2009). [Studies on the Chemical Constituents of Xanthoceras Sorbifolia]. Zhong Yao Cai 32 (5), 702-704. doi:10.13863/ j.issn1001-4454.2009.05.039

Panyadee, A., Sahakitpichan, P., Ruchirawat, S., and Kanchanapoom, T. (2015). 5methyl Ether Flavone Glucosides from the Leaves of Bruguiera Gymnorrhiza. Phytochemistry Lett. 11, 215-219. doi:10.1016/j.phytol.2014.12.021

Pharmacopoeia Committee of the Ministry of Health of the People's Republic of China (1998). The Ministry of Health of the People's Republic of China Drug Standards. Beijing, China: Mongolian Med.

Qi, Y., Ji, X. F., Chi, T. Y., Liu, P., Jin, G., Xu, Q.., et al. (2017). Xanthoceraside Attenuates Amyloid $\beta$ Peptide1-42-Induced Memory Impairments by Reducing Neuroinflammatory Responses in Mice. Eur. J. Pharmacol. 820, 18-30. doi:10.1016/j.ejphar.2017.11.045

Qi, Y., Zou, L.-B., Wang, L.-H., Jin, G., Pan, J.-J., Chi, T.-Y., et al. (2013). Xanthoceraside Inhibits Pro-inflammatory Cytokine Expression in A $325-35 /$ ifn- $\gamma$-Stimulated Microglia through the TLR2 Receptor, MyD88, Nuclear Factor-Kb, and Mitogen-Activated Protein Kinase Signaling Pathways. J. Pharmacol. Sci. 122 (4), 305-317. doi:10.1254/jphs.13031fp

Qu, W., Chen, J. P., and Tian, S. Y. (2000). Poptosis Induced by $\beta$-amyloid Protein in Rat Brain and protection by Melatonin in the Rat Brains. Chin. J. Neurol. 33 (1), 729.

Rajendiran, V., Natarajan, V., and Devaraj, S. N. (2018). Anti-inflammatory Activity of Alpinia Officinarum Hance on Rat colon Inflammation and Tissue Damage in DSS Induced Acute and Chronic Colitis Models. Food Sci. Hum. Wellness 7 (4), 273-281. doi:10.1016/j.fshw.2018.10.004

Rong, W., Ding, K., Guo, S., Xie, F., Li, Q., and Bi, K. (2019). Metabolomics Analysis of Xanthoceras Sorbifolia Husks protection of Rats against Alzheimer's
Disease Using Liquid Chromatography Mass Spectrometry. J. Chromatogr. B Analyt Technol. Biomed. Life Sci. 1126-1127, 121739. doi:10.1016/ j.jchromb.2019.121739

Rong, W., Ding, K., Guo, S., Yuan, Z., Li, Q., and Bi, K. (2018). A Time-Of-Flight Mass Spectrometry Based Strategy to Fast Screen Triterpenoids in Xanthoceras Sorbifolia Bunge Husks for Bioactive Substances against Alzheimer's Disease. RSC Adv. 8 (27), 14732-14739. doi:10.1039/C8RA01765D

Si, Q. (1996). Good Effect on Acne of WenGuanMu Sanwei Decoction. Chin. Folk Therapy. (6), 30-31. doi:10.19621/j.cnki.11-3555/r.1996.06.041

Small, D. M., Coombes, J. S., Bennett, N., Johnson, D. W., and Gobe, G. C. (2012). Oxidative Stress, Anti-oxidant Therapies and Chronic Kidney Disease. Nephrology (Carlton) 17 (4), 311-321. doi:10.1111/j.1440-1797.2012.01572.x

Sun, Z., Li, Q., and Bi, K. (2018). Rapid HPLC-ESI-MS/MS Analysis of Neurotransmitters in the Brain Tissue of Alzheimer's Disease Rats before and after Oral Administration of Xanthoceras Sorbifolia Bunge. Molecules 23 (12), 3111. doi:10.3390/molecules 23123111

Testai, L. (2015). Flavonoids and Mitochondrial Pharmacology: A New Paradigm for Cardioprotection. Life Sci. 135, 68-76. doi:10.1016/j.lfs.2015.04.017

Tian, Y. H., Yao, Z. B., Zhou, L. H., and Xie, Y. (2001). A $\beta_{5-35}$ and Apo E4 Enhance Neuronal Intracellular Free $\mathrm{Ca}^{2+}$. Chin. Pharmacol. Bull. 7 (1), 57-61. doi:10.3321/j.issn:1001-1978.2001.01.017

Uttara, B., Singh, A. V., Zamboni, P., and Mahajan, R. T. (2009). Oxidative Stress and Neurodegenerative Diseases: a Review of Upstream and Downstream Antioxidant Therapeutic Options. Curr. Neuropharmacol. 7 (1), 65-74. doi:10.2174/157015909787602823

Venegas-Calerón, M., Ruíz-Méndez, M. V., Martínez-Force, E., Garcés, R., and Salas, J. J. (2017). Characterization of Xanthoceras Sorbifolium Bunge Seeds: Lipids, Proteins and Saponins Content. Ind. Crops Prod. 109, 192-198. doi:10.1016/j.indcrop.2017.08.022

Wan, G. S., Ren, Y. H., Gao, H. Y., Bai, S., Xi, R. G., Wang, X. B., et al. (2015). Isolation and Identification of Chemical Constituents from the Husks of Xanthoceras Sorbifolium Bunge. J. Shenyang Pharm. Univ. 32 (1), 18-21. doi:10.14066/j.cnki.cn21-1349/r.2015.01.004

Wan, G. S., Wang, X. B., Wu, L. J., and Gao, H. Y. (2013). Advances in Studies on Chemical Constituents of Xanthoceras Sorbifolia and Their Pharmacological Activities. Chin. Tradit. Herbal. Drugs 13 (44), 1842-1851. doi:10.7501/ j.issn.0253-2670.2013.13.027

Wan, Q. F., He, J. F., and Zhang, W. H. (2010). Distribution and Bio-Ecological Characteristics of Xanthoceras Sorbifolia Bunge. Acta Agric. Boreali-occidentalis Sin. 19 (9), 179-185. doi:10.3724/SP.J.1142.2010.40486

Wang, D., Su, D., Yu, B., Chen, C., Cheng, L., Li, X., et al. (2016b). Novel Antitumour Barringenol-like Triterpenoids from the Husks of Xanthoceras Sorbifolia Bunge and Their Three Dimensional Quantitative Structure Activity Relationships Analysis. Fitoterapia 116, 51-60. doi:10.1016/ j.fitote.2016.11.002

Wang, D., Yu, B., Chen, C., Duan, J., Di, D., Xiong, X., et al. (2018). New Natural Barrigenol-like Triterpenoid Isolated from the Husks of Xanthoceras Sorbifolia Bunge. Nat. Prod. Res. 32 (9), 997-1003. doi:10.1080/14786419.2017.1375916

Wang, D., Su, D., Li, X.-Z., Liu, D., Xi, R.-G., Gao, H.-Y., et al. (2016a). Barrigenol Triterpenes from the Husks of Xanthoceras Sorbifolia Bunge and Their Antitumor Activities. RSC Adv. 6 (33), 27434-27446. doi:10.1039/c6ra02706g

Wang, H. D. (1998). Research Progress on the Chemical Composition and Comprehensive Utilization of Xanthoceras Sorbifolia Bunge. Chin. Wild Plant Resour. 17 (1), 13-16.

Wang, Y., Jiang, S., Meng, D. L., and Li, N. (2011). Advances in Study on Chemical and Biological Activity of Xanthoceras Sorbifolia. Drugs Clin. 26 (04), 269-273. doi:10.7501/j.issn.1674-5515

Wu, D. D. (2017). Isolation and Identification of the Chemical Constituents of Xanthoceras Sorbifolia wood and Pharmacokinetic Investigation of its Seven Major Chemical Constituents. China: Inner Mongolia Univ. Inner Mongolia.

Xiao, W., Wang, Y., Zhang, P., Li, N., Jiang, S., Wang, J. H., et al. (2013). Bioactive Barrigenol Type Triterpenoids from the Leaves of Xanthoceras Sorbifolia Bunge. Eur. J. Med. Chem. 60, 263-270. doi:10.1016/j.ejmech.2012.12.022

Xie, Z. W. (1996). National Chinese Herbal Medicine Compilation. Beijing, China: People's Medical Publishing House.

Xie, Z., Zhang, W., and Liu, X. (2010). Growth and Physiological Characteristics of Xanthoceras Sorbifolia Seedlings under Soil Drought Stress. Acta Bot. Borealioccidentalia Sin. 30 (05), 948-954. doi:10.3724/SP.J.1231.2010.06705 
Xu, D. X., and Yu, H. Z. (2010). Xanthoceras Sorbifolia Biology. Beijing: Sci. Press. Xu, J. K., Zhang, W., Li, Y. J., Ji, X. F., Chi, T. Y., Zou, L. B., et al. (2014). Effects of Xanthoceraside on Focal Cerebral Ischemiareperfusion Injury in Rats and the Preliminary Mechanism Study. J. Shenyang Pharm. Univ. 31 (10), 793-798. doi:10.14066/j.cnki.cn21-1349/r.2014.10.008

Yan, D. J. (2007). Study on Xanthoceras Sorborifolia Resources and its Development Utilization in China. J. Shanxi Agric. Sci. 35 (3), 15-17. doi:10.3969/j.issn.1002-2481.2007.03.004

Yan, M. H., Li, P. W., and Xiong, L. Z. (1984). Isolation, Estimation and Identification of the Sterols in Unsaponifiable Fraction of the Oil from Xanthoceras Sorbifolia Bunge. Sci. Silvae Sin. 20 (4), 389-396.

Yang, A., Zhang, F., Ma, S., Qi, G., Shang, H., Zheng, Z., et al. (2020a). Chemical Constituents of the Fruit Husk of Xanthoceras Sorbifolia. Chem. Nat. Compd. 56 (2), 325-327. doi:10.1007/s10600-020-03020-3

Yang, C. Y., Ha, W., Lin, Y., Jiang, K., Yang, J. L., Shi, Y. P., et al. (2016a). Polyphenols Isolated from Xanthoceras Sorbifolia Husks and Their Anti-tumor and RadicalScavenging Activities. Molecules 21 (12), 1694. doi:10.3390/molecules21121694

Yang, C. Y., Yang, J. L., Ha, W., and Shi, Y. P. (2016b). Advances in Studies on Chemical Constituents from Husks of Xanthoceras Sorbifolia and Their Biological Activities. Chin. Tradit. Herbal Drugs 47 (8), 1418-1424. doi:10.7501/j.issn.0253-2670.2016.08.029

Yang, L., Hou, A., Zhang, J., Wang, S., Man, W., Yu, H., et al. (2020b). Panacis Quinquefolii Radix: A Review of the Botany, Phytochemistry, Quality Control, Pharmacology, Toxicology and Industrial Applications Research Progress. Front. Pharmacol. 11. doi:10.3389/fphar.2020.602092

Yao, Z.-Y., Qi, J.-H., and Yin, L.-M. (2013). Biodiesel Production from Xanthoceras Sorbifolia in China: Opportunities and Challenges. Renew. Sustain. Energ. Rev. 24, 57-65. doi:10.1016/j.rser.2013.03.047

Yi, N., Wang, X. M., and Ding, L. J. (2011). Ultrasonic Treatment of Activated Carbon Made by Xanthoceras Sorbifolia Bunge Husk and Their Use on Methylene Blue Adsorption. J. Northeast. Agric. Univ. 42 (11), 77-82. doi:10.19720/j.cnki.issn.1005-9369.2011.11.014

Yu, L., Tang, X., Chen, L., Wang, M., Jian, J., Cao, S., et al. (2012b). Oleanane-type Triterpenoid Saponins from Xanthoceras Sorbifolia Bunge. Fitoterapia 83 (8), 1636-1642. doi:10.1016/j.fitote.2012.09.015

Yu, L., Wang, X., Wei, X., Wang, M., Chen, L., Cao, S., et al. (2012a). Triterpenoid Saponins from Xanthoceras Sorbifolia Bunge and Their Inhibitory Activity on Human Cancer Cell Lines. Bioorg. Med. Chem. Lett. 22 (16), 5232-5238. doi:10.1016/j.bmcl.2012.06.061

Yu, L., Liu, J., Yu, L., Chen, L., and Qiu, F. (2018). Chemical Constituents of Seed Oil Leavings of Xanthoceras Sorbifolia. Chem. Nat. Compd. 54 (4), 769-771. doi:10.1007/s10600-018-2469-x

Zhang, H., and Zhou, Q. (2013a). Tyrosinase Inhibitory Effects and Antioxidative Activities of Saponins from Xanthoceras Sorbifolia Nutshell. Plos. ONE. 8 (8), e70090. doi:10.1371/journal.pone.0070090

Zhang, H. M., Geng, J., and Zhou, Q. C. (2013). Tyrosinase Inhibitory Effects of Flavonoids from Xanthoceras Sorbifolia Nutshell. Chin. J. Cereals. Oils. 28 (10), 96-100.

Zhang, Q. L., Yan, G., Yang, Z. Q., Wang, B., Zhang, M. H., Liu, L., et al. (2012). The Biological Characteristics and Economic Value of Xanthoceras Sorbifolia and its Development and Utilization Prospects. Agric. Sci. Technol. 10, 202-203.

Zhang, S., Zu, Y. G., Fu, Y. J., Luo, M., Liu, W., Li, J., et al. (2010). Supercritical Carbon Dioxide Extraction of Seed Oil from Yellow Horn (Xanthoceras Sorbifolia Bunge.) and its Anti-oxidant Activity. Bioresour. Technol. 101 (7), 2537-2544. doi:10.1016/j.biortech.2009.11.082

Zhang, W. X., and Bao, W. F. (2000). Studies on the Chemical Constituents of Xanthoceras Sorbifolia Bunge. Acta Pharm. Sin. 35 (2), 124-127. doi:10.16438/ j.0513-4870.2000.02.010
Zhang, X., Guo, S., Ho, C.-T., and Bai, N. (2020). Phytochemical Constituents and Biological Activities of Longan (Dimocarpus Longan Lour.) Fruit: A Review. Food Sci. Hum. Wellness 9 (2), 95-102. doi:10.1016/ j.fshw.2020.03.001

Zhang, Y., Ma, J. N., Ma, C. L., Qi, Z., and Ma, C. M. (2015). Simultaneous Quantification of Ten Constituents of Xanthoceras Sorbifolia Bunge Using UHPLC-MS Methods and Evaluation of Their Radical Scavenging, DNA Scission Protective, and a-glucosidase Inhibitory Activities. Chin. J. Nat. Med. 13 (11), 873-880. doi:10.1016/S1875-5364(15)30092-3

Zhang, Y. L., Xiao, H. F., Shi, H. X., Song, Z. X., and Tang, Z. S. (2017). Antioxidant Activity of Fruit Shells of Xanthoceras Sorbifolia Bunge and Screening of Active Components Inhibiting Proliferation of HepG2 Cell Line. Mod. Chin. Med. Nov. 19 (11), 1572-1574. doi:10.13313/j.issn.16734890.2017.11.015

Zhang, Z. Y., Wang, K., Li, H., Liu, J. Y., Deng, H., and Qi, N. (2016). Antioxidant and Anti-hepatoma Activities of Total Saponins from Kernel of Xanthoceras Sorbifolia Bunge. Nat. Prod. Res. Dev. 28, 1012-1019. doi:10.16333/j.10016880.2016.7.005

Zhao, C. Y., Su, H., and Zhao, Y. S. (2008). Comprehensive Development and Utilization Value of Xanthoceras Sorbifolia. Inner Mongol. For. Invest. Des. 31 (6), 118-119.

Zhao, D. D., Li, D. Y., Hu, H. M., and Li, Z. L. (2013). A New Monoterpenoid Isolated from Flowers of Xanthoceras Sorbifolia. Chin. Tradit. Herbal Drugs 44 (1), 11-15. doi:10.7501/j.issn.0253-2670.2013.01.003

Zhao, D. D., Li, D. Y., Wei, J. X., Hu, H. M., and Li, Z. L. (2012). Isolation and Structural Identification of the Chemical Constituents from the Flowers of Xanthoceras Sorbifolia Bunge. J. Shenyang Pharm. Univ. 29 (7), 514-518. doi:10.14066/j.cnki.cn21-1349/r.2012.07.002

Zhao, L., Li, X., Ye, Z. Q., Zhang, F., Han, J. J., Yang, T., et al. (2018). Nutshell Extracts of Xanthoceras Sorbifolia: a New Potential Source of Bioactive Phenolic Compounds as a Natural Antioxidant and Immunomodulator. J. Agric. Food Chem. 66 (15), 3783-3792. doi:10.1021/acs.jafc.7b05590

Zhou, H., Tai, J., Xu, H., Lu, X., and Meng, D. (2019). Xanthoceraside Could Ameliorate Alzheimer's Disease Symptoms of Rats by Affecting the Gut Microbiota Composition and Modulating the Endogenous Metabolite Levels. Front. Pharmacol. 10, 1035. doi:10.3389/fphar.2019.01035

Zhu, H. J., Yu, L. L., Liu, J. C., Wang, M. Y., Zhang, T., Feng, Q., et al. (2018). A New Coumarin Glucoside Ester from Seeds Oil Leavings of Xanthoceras Sorbifolia Bunge. Chin. Tradit. Herbal Drugs 11, 113-115. doi:10.1016/ j.chmed.2018.09.003

Conflict of Interest: The authors declare that the research was conducted in the absence of any commercial or financial relationships that could be construed as a potential conflict of interest.

Publisher's Note: All claims expressed in this article are solely those of the authors and do not necessarily represent those of their affiliated organizations, or those of the publisher, the editors and the reviewers. Any product that may be evaluated in this article, or claim that may be made by its manufacturer, is not guaranteed or endorsed by the publisher.

Copyright $\odot 2021$ Zang, Qiu, Chen, Li, Liu, Zhang, Liu and Li. This is an open-access article distributed under the terms of the Creative Commons Attribution License (CC $B Y)$. The use, distribution or reproduction in other forums is permitted, provided the original author(s) and the copyright owner(s) are credited and that the original publication in this journal is cited, in accordance with accepted academic practice. No use, distribution or reproduction is permitted which does not comply with these terms. 